\title{
Tectonic and magmatic segmentation of the Global Ocean Ridge System: a synthesis of observations
}

\author{
SUZANNE M. CARBOTTE ${ }^{1 *}$, DEBORAH K. SMITH ${ }^{2}$, MATHILDE CANNAT $^{3} \&$ \\ EMILY M. KLEIN ${ }^{4}$ \\ ${ }^{1}$ Lamont-Doherty Earth Observatory of Columbia University, Palisades, NY 10964, USA \\ ${ }^{2}$ Woods Hole Oceanographic Institution, Woods Hole Massachusetts 02543, USA \\ ${ }^{3}$ Equipe de Géosciences Marines, CNRS-UMR 7154, Institut de Physique du Globe, \\ 1 rue Jussieu, 75238 Paris cedex 05, France \\ ${ }^{4}$ Nicholas School of the Environment, Duke University, Durham, NC 27708, USA \\ *Corresponding author (e-mail: carbotte@ldeo.columbia.edu)
}

\begin{abstract}
Mid-ocean ridges display tectonic segmentation defined by discontinuities of the axial zone, and geophysical and geochemical observations suggest segmentation of the underlying magmatic plumbing system. Here, observations of tectonic and magmatic segmentation at ridges spreading from fast to ultraslow rates are reviewed in light of influential concepts of ridge segmentation, including the notion of hierarchical segmentation, spreading cells and centralized v. multiple supply of mantle melts. The observations support the concept of quasi-regularly spaced principal magmatic segments, which are $30-50 \mathrm{~km}$ long on average at fast- to slow-spreading ridges and fed by melt accumulations in the shallow asthenosphere. Changes in ridge properties approaching or crossing transform faults are often comparable with those observed at smaller offsets, and even very small discontinuities can be major boundaries in ridge properties. Thus, hierarchical segmentation models that suggest large-scale transform fault-bounded segmentation arises from deeper level processes in the asthenosphere than the finer-scale segmentation are not generally supported. The boundaries between some but not all principal magmatic segments defined by ridge axis geophysical properties coincide with geochemical boundaries reflecting changes in source composition or melting processes. Where geochemical boundaries occur, they can coincide with discontinuities of a wide range of scales.
\end{abstract}

\section{Discovery and interpretations of mid-ocean ridge (MOR) segmentation: historical review}

Early maps of the global mid-ocean ridge (MOR) system showed that spreading centres are segmented at scales of up to hundreds of kilometres by large-offset transform faults (TFs), some of which are inherited from continental breakup. As more detailed maps of the ocean floor became available in the 1970s and 1980s, ubiquitous smaller offset discontinuities were discovered that segment the ridge axis at shorter intervals (e.g. Hey 1977; Hey et al. 1980; Schouten \& Klitgord 1982; Lonsdale 1983, 1985; Francheteau \& Ballard 1983; Macdonald et al. 1984; Schouten et al. 1985; Langmuir et al. 1986; Sempéré et al. 1990). These discontinuities were found to be distinct from TFs because they typically lack the narrow zone of spreading-parallel lineaments indicative of localized strike-slip faulting. Together, TFs and these non-transform discontinuities define the tectonic segmentation of the global MOR system.
An important type of non-transform offset (NTO), first recognized at intermediate-spreading ridges, is called a propagating rift (PR) because, at these discontinuities, one ridge segment, the 'PR', advances into older crust adjacent to the 'dying rift', which retreats (Hey 1977; Hey et al. 1980). PRs leave a distinctive $\mathrm{V}$-shaped wake of magnetic and bathymetric anomalies on the ridge flanks. Along the fast-spreading East Pacific Rise (EPR), an NTO, similar in many ways to a PR, was later discovered, called an overlapping spreading centre (OSC), where two en echelon ridge segments overlap (e.g. Macdonald \& Fox 1983; Lonsdale 1983; Macdonald et al. 1984, 1988). Like PRs, OSCs can persist for millions of years and, in most cases, migrate along the ridge axis, leaving $\mathrm{V}$-shaped wakes of disrupted seafloor. On an even finer scale, high-resolution mapping of the EPR (e.g. Macdonald et al. 1984) led to the identification of yet smaller, shorter-lived ridge offsets, referred to as 'devals' for deviations from axial linearity (Langmuir et al. 1986).

At slow-spreading ridges, 'zero-offset transform faults (ZOTs)' were identified from small offsets in 


\section{S. M. CARBOTTE ET AL.}

magnetic anomalies in old North Atlantic crust, which were inferred to persist for tens of million years while also changing in length and sense of offset (e.g. Schouten \& White 1980; Schouten \& Klitgord 1982). Subsequent mapping investigations of the Mid-Atlantic Ridge (MAR) axis revealed small jogs or oblique-trending portions of the rift valley spaced at similar intervals as the ZOTs inferred in old crust (e.g. Schouten et al. 1985; Sempéré et al. 1990). In some places these NTOs remain stationary and in other places they migrate along the ridge axis (e.g. Schouten et al. 1987).

Another early discovery was that regular variations in the depth of the ridge axis and other along-strike ridge properties accompany the tectonic segmentation (e.g. Le Douaran \& Francheteau 1981; Francheteau \& Ballard 1983; Macdonald et al. 1984; Schouten et al. 1985). TFs and the newly recognized smaller offset NTOs were found to coincide with local deep points along the ridge axis, with the ridge shoaling away from these discontinuities, forming arched-shaped along-axis topographic profiles. These variations in seafloor depth were attributed to changes in the density structure of the crust and mantle below, with the deep ridge regions interpreted as sites of higher densities resulting from thinner crust and/or cooler crust and upper mantle temperatures (e.g. Francheteau \& Ballard 1983; Macdonald et al. 1984). While initial studies attributed the deepening of the ridge axis near TFs to a decrease in aesthenospheric melting due to the juxtaposition of older and hence colder lithosphere across the discontinuity (e.g. Fox \& Gallo 1984), further work showed that the predicted conductive cooling effects were insufficient to generate the increase in seafloor depth (e.g. Forsyth \& Wilson 1984). Furthermore at OSCs and smaller discontinuities along the EPR, thermal edge effects due to the contrast in lithospheric age across these offsets $(<0.25 \mathrm{Ma})$ are expected to be negligible. An alternate explanation for the apparent decrease in melt volume near these discontinuities was therefore needed.

The concept of a 'spreading cell' was introduced in the early 1980 s to explain axial variations associated with tectonic segmentation. Based on the apparent long-lived coherence of oceanic lithosphere accreted between fracture zones in the North Atlantic and what were later recognized as NTOs along the MAR, and the quasi-regular spacing of these ridge segments, Schouten \& White (1980), Schouten \& Klitgord (1982) and Schouten et al. (1985) advanced the notion of a 'spreading centre cell', a length of ridge representing an independent, long-lived, accretionary unit. Drawing on data from the EPR, Francheteau \& Ballard (1983) further suggested that these spreading cells exhibit systematic along-axis topographic, volcanic, tectonic and hydrothermal gradients, which may result from central supply of melt to segment centres and redistribution of melt toward segment ends. In this model, the deeper seafloor typically found at NTOs, which are too small in offset to produce significant cold edge effects, reflects diminished magma supply at the distal ends of the upwelling centres (Macdonald et al. 1984). These and subsequent studies led to the view that each spreading cell has its own physically distinct melt supply system in the asthenosphere; and, further, that the relatively regular spacing of these melt supply systems results from diapiric ascent of Rayleigh-Taylor-type gravitational instabilities that develop in partially molten mantle (Schouten \& Klitgord 1982; Francheteau \& Ballard 1983; Whitehead et al. 1984; Crane 1985; Schouten et al. 1985; Rabinowicz et al. 1987).

With increasing recognition that the MOR system exhibits segmentation at a range of spatial scales, the model of melt supply centres evolved to include the possibility of a hierarchy of nested magmatic segmentation with a branching, alongaxis melt redistribution system arising from variations in the depth and spatial scales of mantle upwelling, melting, melt segregation and delivery (Fig. 1; Langmuir et al. 1986; Macdonald et al. 1988). Geochemical studies of along-axis variations in melt composition played a key role in exploring this model, based on the assumption that geochemical segmentation (lengths of ridge with common geochemical characteristics) is representative of magmatic segmentation (lengths of ridge fed by a common magma plumbing system). Within the larger-scale segments identified as spreading cells, geochemical studies identified along-axis variations in magma composition reflecting differences in mantle source composition and extents and pressures of melting at shorter spatial scales, suggesting multiple melt injection sites beneath these segments (e.g. Langmuir \& Bender 1984; Langmuir et al. 1986; Niu \& Batiza 1994; Reynolds \& Langmuir 1997). Detailed sampling of the fast-spreading EPR revealed that even the smallest tectonic boundaries (devals) can coincide with changes in magma compositions (Langmuir et al. 1986).

Other models have been proposed for the origin of ridge segmentation and can be grouped broadly into those that invoke tectonic processes associated with the rifting of young lithosphere (e.g. Sandwell 1986; Lonsdale 1989) and those that invoke mantle upwelling, melting processes, melt segregation and transport (e.g. Whitehead et al. 1984; Crane 1985; Schouten et al. 1985; Rabinowicz et al. 1987; Spiegelman \& McKenzie 1987; Parmentier \& Phipps Morgan 1990; Sparks \& Parmentier 1991, 1993; Lin \& Phipps Morgan 1992; Nicolas et al. 1994; Rabinowicz \& Briais 2002; Toomey et al. 2007; Hebert \& Montési 2011). The prevailing 
(a) 1st-3rd Order Discontinuities and Segments
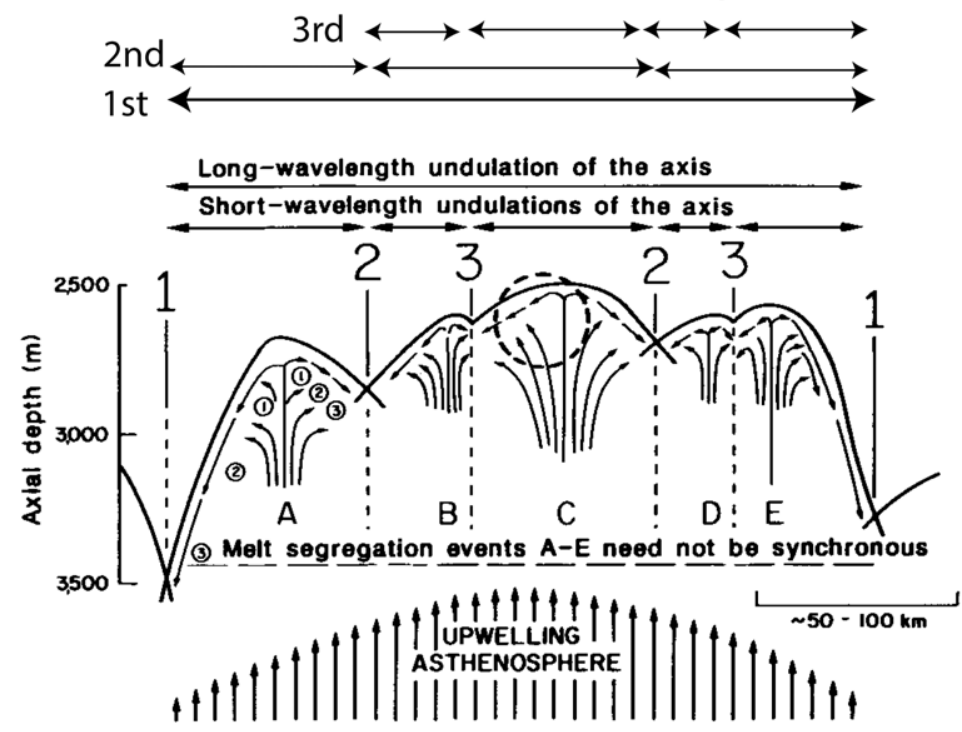

(b) 4th Order Discontinuities and Segments

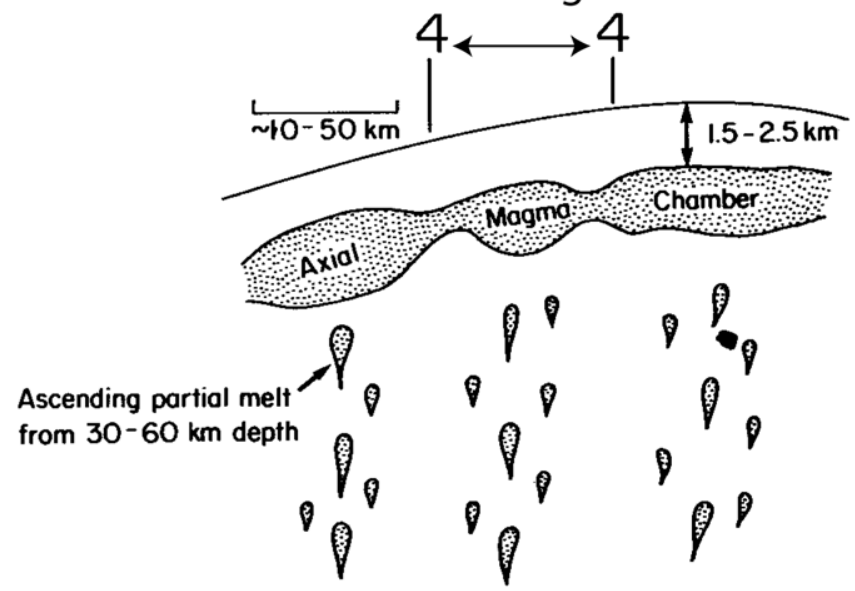

Fig. 1. Schematic illustration of hierarchical central magma supply model for magmatic segmentation from Macdonald et al. (1988). (a) Axial depth profile shows undulations in seafloor depth along the ridge axis with discontinuities of orders 1-3 located at local depth maximum. Transform faults or first-order discontinuities are located at the deepest points along the ridge; second- and third-order offsets are associated with smaller depth anomalies; these discontinuities bound segments of different orders (as indicated with labelled horizontal arrows above). Asthenospheric upwelling at depth is enhanced beneath the shallowest part of the ridge. In the shallower mantle, melt segregation events lead to focusing of magma supply beneath the mid-segment regions of second- and third-order segments, followed by along-axis redistribution of magma. (b) Focused mantle melt supply replenishes crustal magma chambers and leads to the finest fourth-order scale of segmentation. Note that discontinuity and segmentation number orders are related; a segment of any order is bound by a discontinuity of the same order at one but not necessarily both ends, with the highest-order offset number governing the designation of the segment order number (e.g. a segment bounded by first- and third-order offsets is a third-order segment).

view is that segmentation at the larger scales arises primarily from the thermochemical properties of the mantle that control patterns of mantle upwelling and melting. However, the dominant mechanisms are poorly understood; multiple processes may contribute at different ridges, perhaps at different length 


\section{S. M. CARBOTTE ET AL.}

and depth scales, and feedbacks between lithospheric and mantle processes are likely important.

\section{The focus of this review}

From the numerous studies conducted in the $c .30$ years since the discovery of MOR segmentation, much has been learned concerning the relationship between tectonic and magmatic segmentation. The identification of tectonic segments, especially those defined by small discontinuities, has been further refined with improved seafloor mapping capabilities. The characterization of magmatic segmentation has also improved with higher resolution geophysical imaging of melt distribution beneath the seafloor and more extensive sampling and chemical characterization of ocean ridge basalts. While the initial models for ridge segmentation were derived primarily from observations of the fast-spreading EPR and slow-spreading MAR, numerous studies of intermediate and ultra-slow ridges have now been conducted that facilitate comparisons of the style and characteristics of segmentation across the full spectrum of spreading rates. Furthermore, dense sampling and focused observations of a range of ridge properties are now available for several regions encompassing different scales of tectonic segmentation suitable for assessing the relationships with magmatic segmentation in detail.

In this contribution we review current observations on MOR segmentation to address the overarching question: Are the different scales of seafloor tectonic segmentation of the MOR coincident with magmatic segmentation of the ridge and, if so, what processes in the crust and mantle magmatic systems are involved?

Drawing upon select regions of ridges spreading at rates from fast to ultra-slow, we review relevant geological, geophysical and geochemical observations. Of particular interest are implications of these observations for the notion of spreading cells, models of central supply v. multiple supply sites beneath segments and the hierarchy of segmentation. Our goal is to provide a summary of current observations for readers interested in MOR studies and magmatic rifting more generally. Given the broad scope of this contribution and extensive literature on the subject, we highlight references that are pivotal to the development of particular ideas. For further discussion of ideas on the origin of segmentation, the reader is referred to excellent prior reviews by Batiza (1996) and Forsyth (1992) and references therein. For an in-depth introduction to MOR processes, see Searle (2013). While much is now known about the structure of backarc spreading centres, we do not consider segmentation in this setting. We also do not discuss the extensive literature on sub-areal rift systems, but rather provide this review of MOR segmentation as a reference for future comparative studies.

In the next sections, characteristics of tectonic and magmatic segmentation that provide further background framework for this review are described briefly.

\section{Characteristics of tectonic segmentation}

The largest-scale physical segmentation of the MOR is defined by the ocean basins, major tectonic plates and regional gradients in ridge properties that extend for thousands of kilometres along the plate boundaries and that are attributed to the influence of deep mantle upwellings or downwellings. Prominent areas of upwelling include hotspots, such as Iceland and the Azores along the northern MAR (Schilling et al. 1983). An example of presumed downwelling, or coldspot, is the Australian-Antarctic Discordance (AAD) along the Southeast Indian Ridge (SEIR) (e.g. Klein et al. 1991; West et al. 1994; Christie et al. 1998).

Superimposed on this regional-scale segmentation is the structural segmentation defined by TFs and NTOs that disrupt the continuity and linearity of the ridge axis (Fig. 1, Table 1). Macdonald et al. (1988) proposed a classification scheme for tectonic offsets of orders one to four with large offset TFs classified as first-order discontinuities and the smallest offsets as fourth order. TFs offset the ridge axis by distances of $>30 \mathrm{~km}$, partition the MOR at intervals of $c .300-500 \mathrm{~km}$, and persist for $10^{7}$ years or more. Second-order discontinuities include large offset OSCs $(c .2-30 \mathrm{~km})$ at fastspreading ridges (e.g. Macdonald et al. 1984) and NTOs (with ridge offset of $<30 \mathrm{~km}$ ) of the axial valley at slow-spreading ridges (e.g. Sempéré et al. 1990, 1993; Grindlay et al. 1991). These features subdivide the ridge at shorter intervals of c. 20$100 \mathrm{~km}$ at slow-spreading ridges and $c .50-250 \mathrm{~km}$ at fast-spreading ridges, and persist for $c .10^{6}$ years or more. This scale of segmentation corresponds with the 'spreading cell' segmentation described above (Schouten \& Klitgord 1982; Whitehead et al. 1984; Francheteau \& Ballard 1983; Crane 1985; Schouten et al. 1985). At fast-spreading ridges small OSCs, and the discontinuities identified as devals by Langmuir et al. (1986), were classified by Macdonald et al. (1988, 1992) as third- and fourth-order discontinuities based on offset length and longevity, with third-order offsets believed to persist for $10^{4}-10^{5}$ years and fourth-order offsets for perhaps a few 1000 years or less. Based on these criteria and the high-resolution bathymetry now available for the EPR, the majority of the offsets identified 
Table 1. Characteristics of Ridge-axis Discontinuities

\begin{tabular}{|c|c|c|c|c|c|c|}
\hline Order & $\begin{array}{l}\text { Spreading } \\
\text { rate }\end{array}$ & Terminology* & $\begin{array}{l}\text { Offset length } \\
(\mathrm{km})\end{array}$ & Discontinuity morphology & Off-axis morphology & Longevity \\
\hline 1 & All & $\begin{array}{l}\text { Transform Fault } \\
\text { (TF) }\end{array}$ & $>30^{\dagger}$ & $\begin{array}{l}\text { Linear valley and transform ridges parallel to } \\
\text { spreading direction }\end{array}$ & $\begin{array}{l}\text { Linear valley and transform } \\
\text { ridges parallel to spreading } \\
\text { direction }\end{array}$ & $\begin{array}{l}\text { Few Ma to } 100 \text { s Ma; no } \\
\text { along-axis migration; TF } \\
\text { can evolve into and from } \\
\text { non-transform offsets }\end{array}$ \\
\hline 2 & Fast & $\begin{array}{l}\text { OSC, Propagating } \\
\text { Rift* }{ }^{\ddagger},\left(\mathrm{NTO}{ }^{\uparrow},\right. \\
\text { Large OSC) }\end{array}$ & c. $2-30^{\dagger},(1-30)^{\S}$ & Overlapping ridges enclosing a basin & $\begin{array}{l}\text { Zones of discordant } \\
\text { topography, can form } \\
\text { v-shaped wake }\end{array}$ & $\begin{array}{l}\text { Few Ma, can evolve from } \\
\text { TF, often migrate along } \\
\text { axis }\end{array}$ \\
\hline 2 & Intermediate & $\begin{array}{l}\text { Overlapping Rift } \\
\text { Zone, OSC, PR, } \\
\text { NTO }^{\boldsymbol{q}}\end{array}$ & $2-$ c. 30 & $\begin{array}{l}\text { Variable. Overlapping ridges or rifts - may enclose } \\
\text { local basin or high. Non-overlapping ridges or } \\
\text { rifts separated by zone of rotated seafloor fabric }\end{array}$ & $\begin{array}{l}\text { Zones of discordant } \\
\text { topography, can form } \\
\text { v-shaped wake if the NTOs } \\
\text { migrate }\end{array}$ & $\begin{array}{l}\text { A few Ma to } 10 \mathrm{~s} \text { of Ma, } \\
\text { can migrate along axis, } \\
\text { disappear or grow into } \mathrm{TF}\end{array}$ \\
\hline 2 & Slow & $\begin{array}{l}\mathrm{NTO}^{\bullet} \text {, oblique } \\
\text { zone, en echelon } \\
\text { offset, } \\
\text { fault-bounded } \\
\text { ridge }\end{array}$ & c. $2-30^{\dagger}$ & $\begin{array}{l}\text { Variable. En echelon offset volcanic axes that may } \\
\text { overlap. Basin or a ridge separates segments. } \\
\text { Shear zones with faults oblique to spreading } \\
\text { normal direction. Detachment faults commonly } \\
\text { form near NTOs }\end{array}$ & $\begin{array}{l}\text { Zones of discordant } \\
\text { topography, can form } \\
\text { v-shaped wake if the NTOs } \\
\text { migrate }\end{array}$ & $\begin{array}{l}\text { A few Ma to } 10 \mathrm{~s} \text { of } \mathrm{Ma}, \\
\text { can migrate along axis, } \\
\text { disappear or grow into } \mathrm{TF}\end{array}$ \\
\hline 2 & Ultra-Slow & $\begin{array}{l}\text { Amagmatic or } \\
\text { non-volcanic } \\
\text { oblique } \\
\text { spreading } \\
\text { domains }\end{array}$ & $\begin{array}{l}\text { c. } 3-30 \text { but } \\
\text { accommodated } \\
\text { in oblique } \\
\text { spreading } \\
\text { domain }\end{array}$ & $\begin{array}{l}\text { Variable. Deep and wide oblique-trending basins up } \\
\text { to } 80 \mathrm{~km} \text { long connecting orthogonal spreading } \\
\text { segments with local shallow volcanic regions. } \\
\text { Detachment faults at segment ends }\end{array}$ & $\begin{array}{l}\text { Wide zones of } \\
\text { oblique-trending basins }\end{array}$ & $\begin{array}{l}10 \mathrm{~s}(?) \text { of Ma, can migrate } \\
\text { along axis, can disappear } \\
\text { or grow into TF }\end{array}$ \\
\hline 3 & Fast & $\begin{array}{l}3^{\text {rd }} \text {-order } \\
\text { discontinuity, } \\
\text { small OSC, } \\
\text { (deval, SNOO) }\end{array}$ & $0.5-2^{\dagger},(0-1)^{\S}$ & $\begin{array}{l}\text { Variable. Overlapping axial ridges enclosing small } \\
\text { basin. } \\
\text { Overlapping Axial Summit Trough (AST) within } \\
\text { axial high and no enclosed basin. } \\
\text { Bathymetric Saddle Points. } \\
\text { Change in orientation of axial high and/or AST } \\
\text { of } 2^{\circ}->5^{\circ} \text { with no offset }\end{array}$ & $\begin{array}{l}\text { Small change in orientation of } \\
\text { ridge flank fabric, can leave } \\
\text { v-shaped trace of offsets in } \\
\text { abyssal hill faults }\end{array}$ & $\begin{array}{l}\text { Perhaps } 100 \text { ka to Ma, } \\
\text { poorly known due to } \\
\text { subtle trace and lack of } \\
\text { sufficient high resolution } \\
\text { ridge flank bathymetry } \\
\text { coverage }\end{array}$ \\
\hline 3-(4?) & Intermediate & Small NTO & $<2$ & $\begin{array}{l}\text { Variable. Change in ridge trend }>5^{\circ} \text {. } \\
\text { Abrupt transition in morphology of axial zone } \\
\text { (e.g. from rifted high to shallow rift). } \\
\text { Small offset or transition in eruptive fissure zone } \\
\text { within rifted axial high. } \\
\text { Offset in AVRs within floor of rift. } \\
\text { Offset or jog in rift walls. }\end{array}$ & $\begin{array}{l}\text { Some display small offsets in } \\
\text { ridge flank faults }\end{array}$ & $\begin{array}{l}\text { Unknown. Some may persist } \\
\text { for } 100 \mathrm{~s} \mathrm{ka}\end{array}$ \\
\hline 4 & Fast & $\begin{array}{l}4^{\text {th }} \text {-order } \\
\text { discontinuity, } \\
\text { deval, (SNOO) }\end{array}$ & $<1^{\dagger},(<0.2)^{\S}$ & $\begin{array}{l}\text { Variable. En echelon jog in AST. Overlapping AST. } \\
\text { Small change in ridge orientation }\end{array}$ & $\begin{array}{l}\text { In some cases small offset or } \\
\text { local narrowing of edge of } \\
\text { axial high }\end{array}$ & 100 s to 10000 years \\
\hline
\end{tabular}

*Current common usage with historical terms included in brackets.

from Macdonald et al. (1992).

*Note that propagating rifts (PRs) at fast-spreading ridges have historically been classified as $1^{\text {st }}$-order offsets; ridge offset across some PRs is larger than $30 \mathrm{~km}$.

${ }^{\S}$ From White et al. (2000).

Non-transform offset (NTO) 


\section{S. M. CARBOTTE ET AL.}

as devals by Langmuir et al. (1986) have now been recognized as longer-lived third-order-type discontinuities (White et al. 2006).

In early studies, it was proposed that analogous third- and fourth-order discontinuities could also be identified along the slow-spreading MAR, defining fine-scale segmentation of this ridge (Macdonald et al. 1988; Grindlay et al. 1991; Sempéré et al. 1993). A third-order discontinuity was defined as a gap between two chains of volcanoes within the rift valley floor marking the locus of spreading, and fourth-order was defined as a gap in a single chain of volcanoes. However, given the complexity of the axial zone at slow-spreading ridges, including the broad distribution of volcanic features within a wide valley floor, it is now recognized that it is not possible to consistently identify fine-scale segmentation of the axial zone at these ridges (e.g. Smith et al. 1995; Table 1).

\section{Characteristics of magmatic segmentation}

Magmatic segmentation refers to lengths of ridge fed by a common magma plumbing system. The plumbing system at MORs extends in depth over several tens of kilometres, from the base of the melting regime in the asthenosphere to crystal mush zones, melt lenses and dykes in the crust (e.g. Sinton \& Detrick 1992). Given this large range in depth and the evidence that mantle melt is strongly focused toward the ridge axis, MOR plumbing systems are often envisioned as subdivided into discrete melt channels or pathways, branching and coalescing at various depths within the system (e.g. Langmuir et al. 1986; Macdonald et al. 1988, Grove et al. 1993; Kelemen et al. 1995; Kelemen \& Aharonov 1998).

The boundaries of magmatic segments are identified along MORs from changes in geophysical properties of the axial zone, such as its density structure inferred from gravity anomalies, its crustal thickness and the geometry and distribution of crustal magma chambers. Magmatic segmentation has also been described based on studies of seafloor rock compositions, which reveal lengths of ridge along which erupted magmas share similar petrogenetic histories (e.g. common source compositions, extents and pressures of melting, and/or extents of crystallization). In general, magmatic segmentation based on geochemical variations is better characterized at faster spreading ridges due to denser sample coverage and better age control than at slower-spreading ridges (e.g. Langmuir et al. 1986; Sinton et al. 1991). However, magmatic segmentation based on geophysical parameters is more readily defined at slow-spreading ridges where large-amplitude variations in the along-axis bathymetry, gravity and seismic structure are found (e.g. Kuo \& Forsyth 1988; Lin et al. 1990; Tolstoy et al. 1993).

From regional-scale studies of ridge-axis lava compositions, ocean-basin-scale variations are observed that are believed to arise from differences in mantle history and composition and proximity to hotspots (e.g. Schilling et al. 1983). Smaller scales of geochemical segmentation have been defined from detailed sampling studies where similar lava compositions are recovered for discrete lengths of the ridge axis (e.g. Langmuir et al. 1986; Sinton et al. 1991, 2003) and from systematic variations in composition approaching TFs and NTOs (e.g. Christie \& Sinton 1981; Bender et al. 1984; Thompson et al. 1985). It has been proposed that the different scales of magmatic segmentation may reflect a depth hierarchy of magmatic processes with larger-scale segments resulting from variations in source composition, or mantle melting processes, and finer-scale segmentation linked to shallowlevel melt segregation processes (e.g. Langmuir et al. 1986; Sinton et al. 1991). Based on detailed sampling of the southern EPR, Sinton et al. (1991) proposed a hierarchy of primary, secondary and tertiary magmatic segments roughly analogous to the orders of tectonic segmentation defined by Macdonald et al. (1988). In this and similar studies, geochemical investigations of magmatic segmentation seek to identify lengths of ridge along which sampled lavas share common magmatic histories, offsets across which abrupt changes in composition occur, or systematic along-axis changes in composition approaching an offset.

\section{Synthesis of observations}

In the following sections and accompanying figures, we summarize observations of ridge properties along tectonically defined segments, as well as at tectonic discontinuities of different orders (Table 1) for ridges spreading at rates from fast to ultraslow. Ridge properties discussed include axial morphology, seafloor geology, axial gravity anomalies, seismic velocity structure and crustal thickness, earthquake distributions and lava geochemistry. Each of these properties provides information on different aspects (and time-scales) of the distribution and delivery of melt from the mantle to form the oceanic crust. The morphology of the axial zone (i.e. rift valley or axial high) is closely linked to the thermal structure and strength of the axial lithosphere (e.g. Chen \& Morgan 1990). Seafloor depth and gravity anomalies along the ridge axis reflect the integrated density structure of the crust and upper mantle, which are linked to the axial thermal structure, crustal thickness and 


\section{SEGMENTATION OF MID-OCEAN RIDGES}

lithology. Geological studies of lava flow types and ages, and faults and fissures along the ridge axis provide constraints on magmatic and tectonic processes and rheological properties. Seismic methods are the primary techniques used to detect the presence of melt and higher temperatures in the crust and mantle and also provide constraints on crustal thickness. Geochemical studies of seafloor samples provide constraints on the composition of the mantle source, and on processes of mantle melting, melt segregation and shallow-level fractionation. While some of these properties (axial morphology, gravity, crustal thickness) reflect timeaveraged magma supply to the ridge on $10^{3}-10^{6}$ year time-scales (variable depending on spreading rate), others reflect magmatic processes from present day to $c$. 100-year time-scales (seismic observations of melt in the crust, geochemical studies of young lavas, seismicity studies).

With this review, we focus our discussion on a number of long-standing questions including:

- What are the geophysical and geochemical signals associated with ridge axis discontinuities and, in particular, the smallest tectonic discontinuities that are better located in modern seafloor mapping data, and do these signals scale with size of ridge offset?

- Do tectonic segments defined by these discontinuities coincide with distinct units in other ridge properties indicative of the distribution of magma in the subsurface?

- Are there systematic gradients in ridge properties within tectonic segments consistent with models of central magma supply (and, if so, over what length scales)?

- Do existing observations support predictions of hierarchical models that longer tectonic segments exhibit larger amplitude variations in ridge properties that result from deeper melt generation or focusing processes?

\section{Fast- and superfast-spreading ridges}

Fast-spreading MORs (80-150 $\mathrm{mm} \mathrm{a}^{-1}$, DeMets et al. 1994) include the northern and southern EPR and portions of the Pacific-Antarctic Ridge. The best-studied regions to date are the northern EPR from $8-18^{\circ} \mathrm{N}$ and the southern EPR from $13-$ $21^{\circ} \mathrm{S}$, and we focus our discussion on these areas (Figs 2-4). Along fast-spreading ridges, the region where new crust forms is marked by an elongate axial high, typically $8-10 \mathrm{~km}$ wide, that rises 200-400 m above surrounding seafloor (e.g. Lonsdale 1983; Macdonald et al. 1984, 1992; Figs 2 \& 3 ). Active volcanism and hydrothermal venting are narrowly focused along the crest of this axial high, usually within a shallow depression (a few tens of metres deep) known as the axial summit trough (Fig. 3; Macdonald \& Fox 1988; Haymon et al. 1991; Fornari et al. 1998).

\section{Geophysical properties of discontinuities and ridge segments}

Transform faults and first-order segments. The TFs that offset the EPR range from $50 \mathrm{~km}$ to $450 \mathrm{~km}$ in length and segment the axis into first-order segments c. 120-600 km long, with several stretches over $1000 \mathrm{~km}$ long (Table 1). Approaching a TF, the ridge axis typically deepens by a few hundred metres over a distance of 5-10 km (Fig. $2 \mathrm{~g}$ ) and the cross-sectional area of the axis, a measure of the width of the axial high, decreases (Fig. 2f; Scheirer \& Macdonald 1993). In some areas, Mantle Bouguer anomalies (MBA), which are gravity anomalies calculated to remove the effects of seafloor topography and a constant thickness and density crust, are somewhat higher $(5-10 \mathrm{mGal})$ approaching TFs, suggesting thinner crust and/or cooler/denser crust and mantle (e.g. Orozco, and Clipperton TF (Fig. 2f, Canales et al. 2003; Cormier et al. 2011) and Garrett TF (Fig. 4f, Magde \& Detrick 1995)). Gregg et al. (2007), however, report lower residual MBA values within some EPR TF domains including the Siqueiros TF, consistent with thicker, not thinner, crust. A seismic tomographic study spanning $c$. $40 \mathrm{~km}$ to either side of the Clipperton TF suggests differences in crustal thickness of no more than $300 \mathrm{~m}$ across this transform (van Avendonk et al. 1998). However, a more regional seismic tomography study shows that the crust gradually thins by up to $1 \mathrm{~km}$ over $c .40 \mathrm{~km}$ towards both the Clipperton and Siqueiros TFs on the east flank of the ridge (Canales et al. 2003).

Across all EPR TFs, a step in the regional depth of the ridge axis is observed, suggesting differences in magma supply to the two adjacent segments. For example, average axial depths along segments bounding the Siquieros, Clipperton and Orozco TFs differ by several hundreds of metres and differences in the thickness of the crust (of 1-2 km) and/ or density of the crust and mantle are inferred, assuming isostatic support for this topography (Figs 2 \& 3, Macdonald et al. 1992; Weiland \& Macdonald 1996). Carbotte et al. (2004) noted that the shallower segment across all EPR TFs corresponds with the 'leading segment', the segment displaced in the migration direction of the ridge axis relative to the underlying asthenosphere, where an asymmetry in melt production may lead to enhanced melt supply (Katz et al. 2004).

Within first-order ridge segments, the longwavelength deepening of the seafloor toward TFs as depicted in early models (Fig. 1) is not observed at many TFs. Instead, seafloor depths along the axis 
(a)

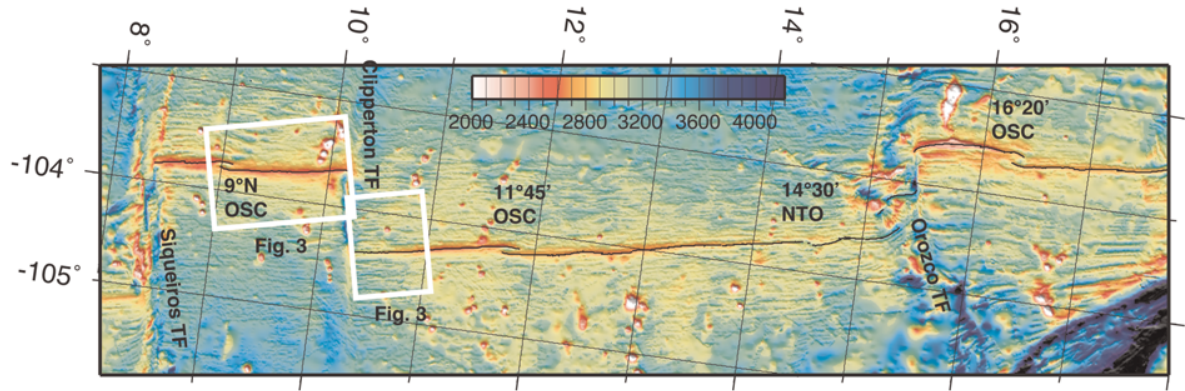

(b)

(d)

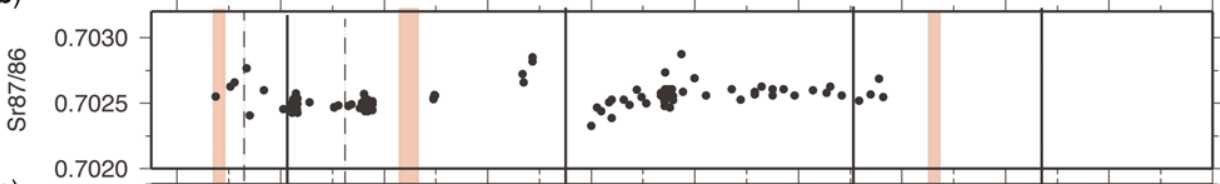

(c)

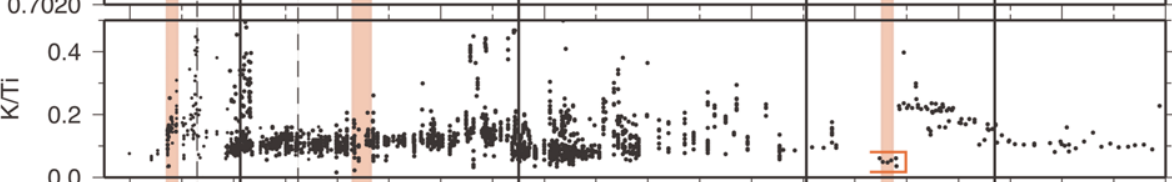

(e)

d
$z$

(f)
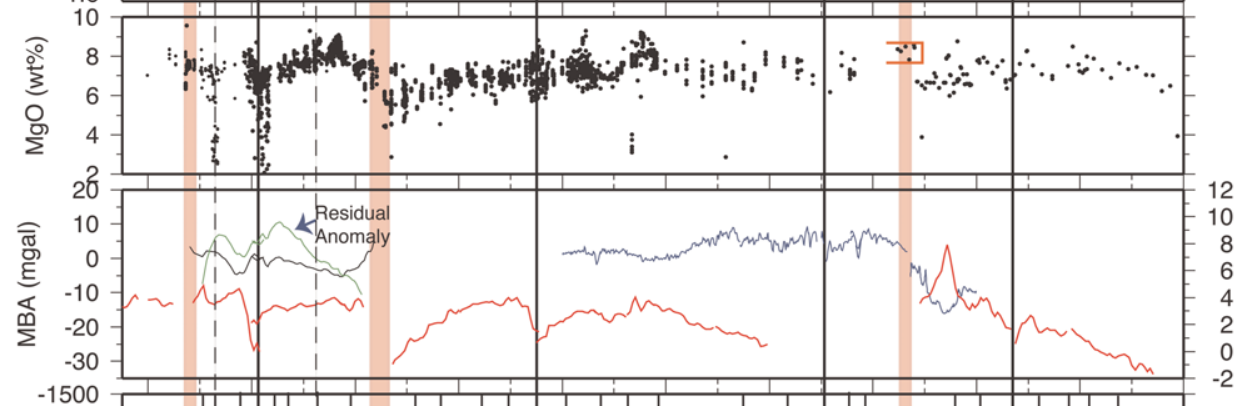

(g)
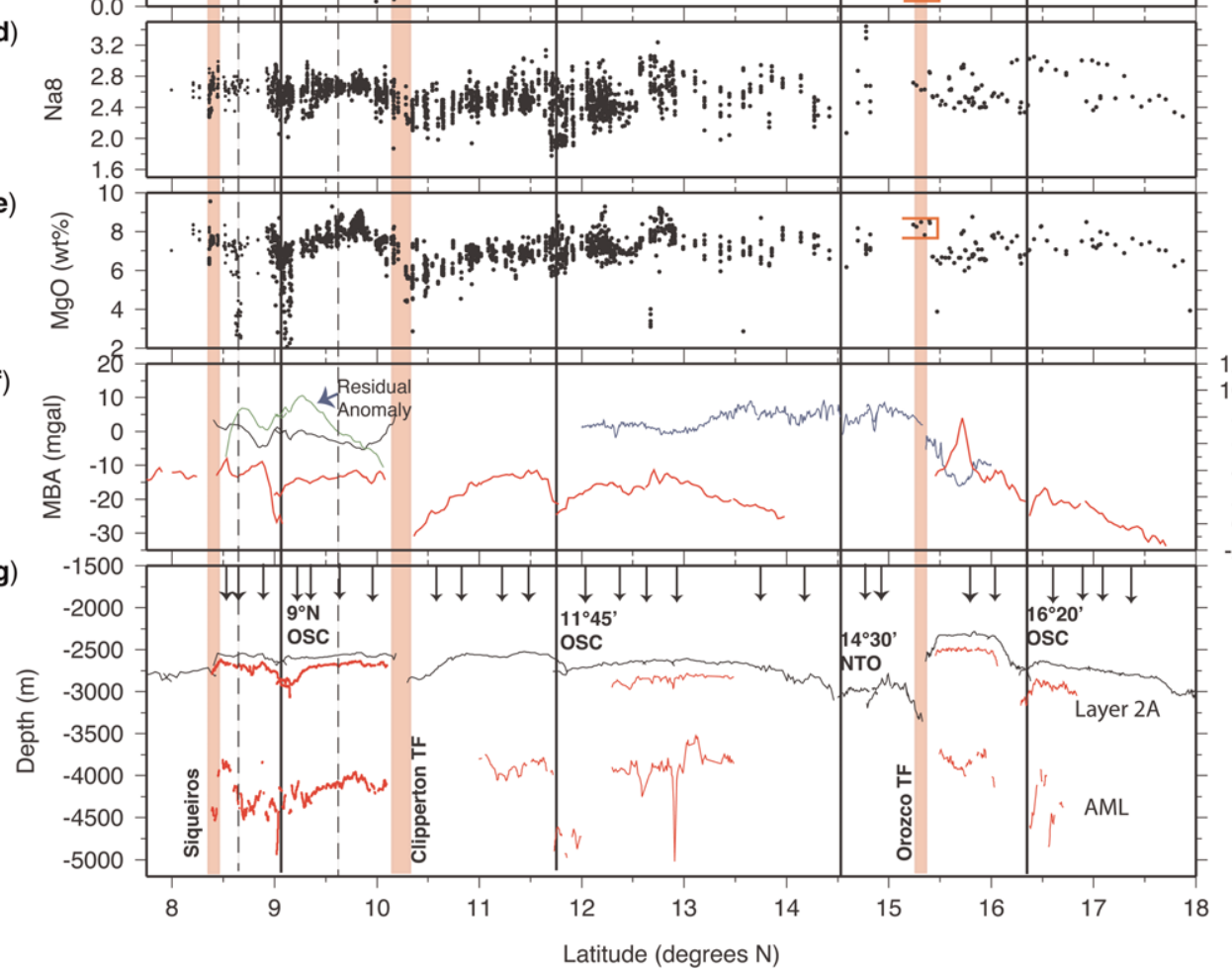

Fig. 2. Variations in ridge properties along the northern East Pacific Rise (EPR). (a) Seafloor bathymetry for the EPR from $8^{\circ}$ to $18^{\circ}$ from the GMRT synthesis (Ryan et al. 2009). All first- and second-order discontinuities are labelled (OSC, overlapping spreading centre; NTO, non-transform offset; TF, transform fault). In lower panels, shaded vertical bars show the locations of transform faults. Bold vertical lines mark the locations of second-order discontinuities, lighter dashed lines mark third-order discontinuities discussed in the text. (b, c) ${ }^{87} \mathrm{Sr} /{ }^{86} \mathrm{Sr}$ ratios and $\mathrm{K} /$ Ti values for ridge axis basalts providing measures of source enrichment. (d) $\mathrm{Na}_{8}$ values, reflecting extent of mantle melting (Klein \& Langmuir, 1987). (e) $\mathrm{MgO}$ (wt\%) reflecting extent of crystal fractionation and temperature of erupted lavas. Geochemical data in panels (b-e) are from C. Langmuir (pers. comm.) and the PetDB synthesis database 


\section{SEGMENTATION OF MID-OCEAN RIDGES}

may remain nearly constant to within a few kilometres of the bounding TFs (e.g. south of the Clipperton (Figs $2 \& 3$ ) and Garrett TFs (Fig. 4)). In some cases, including south of Clipperton, the ridge axis appears to 'overshoot' the transform domain with volcanic ridges extending on to older crust across the TF (e.g. Fig. 3a; Barth et al. 1994).

Prominent examples where long-wavelength gradients are observed include north of Clipperton and south of Orozco where the EPR axis gradually deepens and narrows over many tens of kilometres approaching these TFs (Fig. 2f, g); these changes in ridge morphology have been attributed to a gradual reduction in magmatic budget in these regions (e.g. Macdonald et al. 1992). North of Clipperton, evidence supporting this hypothesis includes the finding that no axial magma lens (AML) has been detected within $c .70 \mathrm{~km}$ north of the TF, although seismic reflection studies image an AML $1-2 \mathrm{~km}$ beneath the seafloor along much of the EPR between $8^{\circ} 30^{\prime} \mathrm{N}$ and $17^{\circ} \mathrm{N}$ (Fig. $2 \mathrm{~g}$, Detrick et al. 1987, 1993; Kent et al. 1993, 2000; Babcock et al. 1998; Carbotte et al. 2000, 2013). Further, lavas erupted over the past $c .1 \mathrm{Ma}$ at the segment north of Clipperton have lower $\mathrm{Mg \# s}$ than those from the south (Mg\# of 5-7 compared with 7-9), indicating lower eruption temperatures and less melt replenishment or greater cooling for the northern segment (Fig. 2e; Batiza et al. 1996). Last, the abyssal hills on the ridge flanks are taller (70$80 \mathrm{~m})$ and narrower $(1.4-2 \mathrm{~km})$ north of Clipperton than those formed at the shallow broad EPR to its south (30-50 $\mathrm{m}$ high, and $2-2.5 \mathrm{~km}$ wide, Goff 1991; Fig. 3a, b) indicating long-lived differences in crustal accretion processes that contribute to the formation of abyssal hills. Yet despite these various observations suggesting reduced magma supply north of Clipperton, available seismic data indicate little difference in crustal thickness across the transform (van Avendonk et al. 1998). It may be that the differences in ridge morphology across this TF are linked more to differences in crustal density associated with iron enrichment rather than crustal thickness, as has been inferred near the $9^{\circ}$ N OSC (Toomey \& Hooft 2008).
Second-order discontinuities and segments. Second-order segments along the EPR range from c. 50 to $230 \mathrm{~km}$ with an average length of $140 \mathrm{~km}$ (Macdonald et al. 1988, 1992). In early studies, described previously, it was proposed that these segments are underlain by focused centres of melt upwelling with lateral redistribution of melts towards the bounding discontinuities, perhaps contributing to the along-axis migration of OSCs. Studies conducted over the past 30 years show that while second-order discontinuities are sites of local disruption in the distribution and supply of melt to the ridge, regional along-axis gradients in ridge properties within second-order segments consistent with a gradual reduction in magma supply towards the bounding offsets are not typically observed (Figs 2,4). The ridge axis usually deepens and narrows within a zone $c .10 \mathrm{~km}$ from a second-order discontinuity, and MBA values may be slightly higher (few $\mathrm{mGal}$ ), consistent with locally reduced magma supply (e.g. at the $9^{\circ} \mathrm{N}$ and $15^{\circ} 55^{\prime} \mathrm{S}$ OSCs; Figs 2 \& 4; Scheirer \& Macdonald 1993). Distinct volcanic mound fields cover the seafloor at OSCs that are thought to result from eruptions at low effusion rates and have been attributed to the presence of small short-lived magma sources that may be widely distributed across the discontinuity zone (White et al. 2009). Seismic studies do not show gradual crustal thinning toward second-order OSCs, expected if these were sites of reduced magma supply at the distal ends of regional mantle upwelling centres. Instead, narrow localized zones of thinner crust (by $1-1.5 \mathrm{~km}$ ) are found within the ridge flank trace of the $9^{\circ} \mathrm{N}$ OSC, and there is no evidence for thin crust at the other small OSCs that have been imaged $\left(12^{\circ} 54^{\prime} \mathrm{N}, 15^{\circ} 55^{\prime} \mathrm{S}\right.$ and near $\left.17^{\circ} \mathrm{S}\right)$ (Barth \& Mutter 1996; Bazin et al. 1998; Canales et al. 1998).

Interestingly, there is evidence that more melt may accumulate and thicker crust may form near some OSCs for reasons that are not well understood. For example, a wide melt lens (up to $4 \mathrm{~km}$ ) is found directly north of the $9^{\circ} \mathrm{N}$ OSC extending to c. $9^{\circ} 17^{\prime} \mathrm{N}$, as well as a band of thicker crust (by c. $1 \mathrm{~km}$ ) centred at $9^{\circ} 15^{\prime} \mathrm{N}$ (Barth \& Mutter 1996; Kent et al. 1993, 2000; Canales et al. 2003;

Fig. 2. (Continued) (see www.petdb.org for original references), re-normalized for differences in reporting iron content and edited to include samples $<2 \mathrm{~km}$ from the ridge axis. (f) Mantle Bouguer Anomaly (black line) measured along axis for $8^{\circ} 30^{\prime}-10^{\circ} \mathrm{N}$ from J. P. Canales (http://www.marine-geo.org/tools/search/Files.php?data_set_uid=333), and Residual Mantle Bouguer Anomaly (blue line) calculated to remove the thermal effects of plate cooling with age for $12-16^{\circ} \mathrm{N}$ from Cormier et al. (2011), and for $15^{\circ} 30^{\prime}-17^{\circ} \mathrm{N}$ from Weiland \& Macdonald (1996). Residual gravity anomaly calculated using seismically inferred crustal thickness is also shown for the $8^{\circ} 30^{\prime}-10^{\circ} \mathrm{N}$ region (green line, from J. P. Canales, http://www.marine-geo.org/tools/search/Files.php?data_set_uid=334) Red line shows ridge cross-sectional area from Scheirer \& Macdonald (1993). (g) Cross-sections along the axis showing seafloor depth from multibeam bathymetry data and the base of layer 2A, and the axial magma lens (AML) imaged in multi-channel seismic data. AML and layer $2 \mathrm{~A}$ observations are from Carbotte et al. (2013) for $8^{\circ} 30^{\prime}-10^{\circ} 10^{\prime} \mathrm{N}$, Detrick et al. (1987) for $10^{\circ} 30^{\prime}-12^{\circ} \mathrm{N}$, Babcock et al. (1998) for $12^{\circ} 30^{\prime}-13^{\circ} 30^{\prime} \mathrm{N}$ and Carbotte et al. (2000) for $15^{\circ} 30^{\prime}-17^{\circ} \mathrm{N}$. Short vertical arrows mark locations of third-order discontinuities modified from White et al. (2006) and Macdonald et al. (1992). 


\section{S. M. CARBOTTE ET AL}

(a)
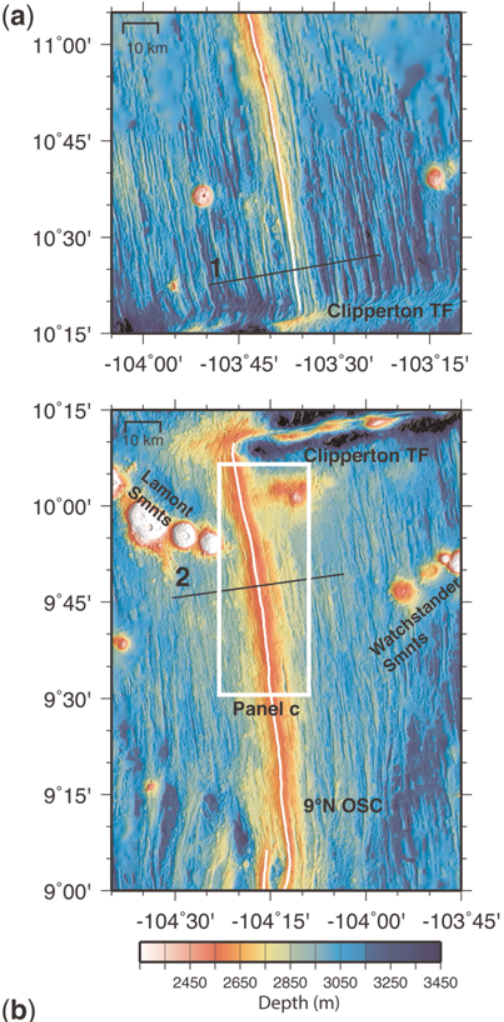

(b)

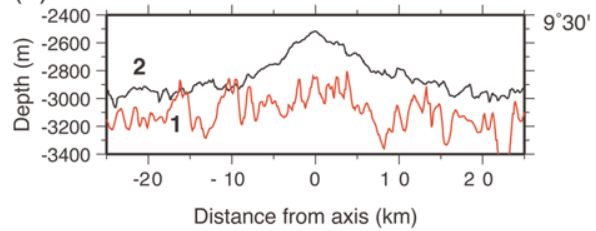

(c)

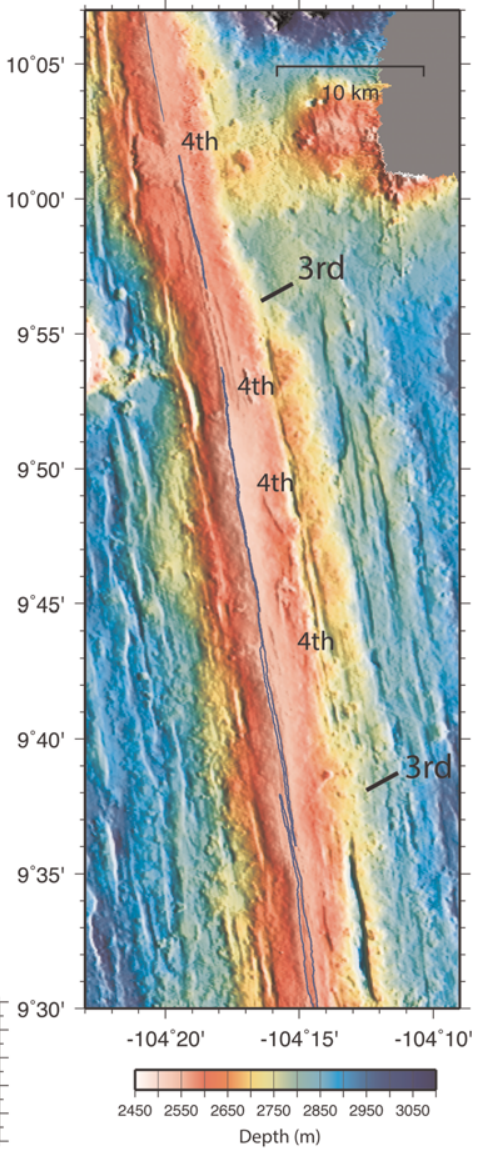

Fig. 3. Bathymetric maps illustrating variations in axial morphology and fine-scale segmentation along the northern EPR (full spreading rate $110 \mathrm{~mm} \mathrm{a}^{-1}$; Carbotte \& Macdonald 1992). (a) Panels show the EPR north (top) and south (bottom) of the Clipperton Transform Fault. The marked differences in seafloor morphology at these two adjacent segments have been attributed to differences in magma supply to each, with more restricted magma supply to the segment to the north. Thin white line shows location of ridge axis. Black lines show location of cross-axis profiles from (b). (b) The EPR north of Clipperton (profile 1) is associated with a narrow $(<2 \mathrm{~km})$ and deep axial high bordered by high-relief (100-200 m) abyssal hills. In contrast, along the EPR south of Clipperton (profile 2), a broad axial high c. $20 \mathrm{~km}$ wide is observed and smooth ridge flank topography with abyssal hills only a few tens of metres high. (c) Close up of the EPR south of Clipperton showing fine-scale segmentation of the axial zone. Third- and fourth-order discontinuities (labelled) are identified from changes in strike of the axial high (third-order) and offsets in the axial summit trough (third- and fourth-order, blue line, Soule et al. 2009), which marks the locus of most recent eruptive fissuring and hydrothermal venting. Bathymetric data are from the GMRT synthesis (Ryan et al. 2009).

Singh et al. 2006a; Combier et al. 2008). Seafloor compliance and seismic tomography studies indicate melt volumes in the crust and uppermost mantle under the ridge axis do not diminish toward the $9^{\circ} \mathrm{N}$ OSC (Crawford \& Webb 2002; Toomey et al. 2007). Indeed, a local region of higher, not lower, melt content is inferred in the shallow mantle beneath the $9^{\circ} \mathrm{N}$ OSC (Dunn et al. 2001;
Toomey et al. 2007). The observations of thicker crust and abundant melt north of the $9^{\circ} \mathrm{N}$ OSC are intriguing and may provide clues regarding processes driving the long-term southward propagation of this offset (e.g. Canales et al. 2003; Klein et al. 2013).

There are, however, some regions where longwavelength changes in ridge properties consistent 


\section{SEGMENTATION OF MID-OCEAN RIDGES}

with a gradual reduction in magma supply towards a second-order discontinuity are observed. Along the southern EPR near the $20^{\circ} 40^{\prime} \mathrm{S}$ OSC, the ridge axis deepens by c. $300 \mathrm{~m}$ and the cross-sectional area of the axis decreases over $100 \mathrm{~km}$ approaching this offset from the north (Fig. 4). From the gradually increasing axial MBA values, Cormier et al. (1995) inferred that thinner crust (by c. $500 \mathrm{~m}$ ) has been accreted north of the $20^{\circ} 40^{\prime} \mathrm{S}$ OSC for the past c. $1.5 \mathrm{Ma}$ or more (Fig. 4f). Notably, these changes in ridge properties are similar in magnitude and length-scale to those observed north of the Clipperton TF (cw Figs 2 \& 4)

There is also evidence in some locations for significant melt focusing beneath a second-order segment. The shallow broad segment between the Orozco TF and the $16^{\circ} 20^{\prime} \mathrm{N}$ OSC is associated with a pronounced MBA low (Fig. 2f), indicating locally thicker crust (by as much as $2.25 \mathrm{~km}$ ) and/ or reduced crust/mantle densities beneath the central part of this segment (Weiland \& Macdonald 1996). However, a small seamount chain extends west of this segment and enhanced magma supply in this region is presumably linked to the interaction of the ridge axis melt regime with that for the ridge flank seamount chain (e.g. Carbotte et al. 2000; Donnelly 2002). Some studies suggest the presence of a melt upwelling centre at $c .9^{\circ} 50^{\prime} \mathrm{N}$, with alongaxis melt flow away from this region (Barth \& Mutter 1996; Wang et al. 1996), although other interpretations have also been advanced (Toomey \& Hooft 2008).

As observed across TFs, adjacent second-order ridge segments often differ significantly in average depth and cross-sectional area, and the differences in these characteristics can be as large as those observed across TFs (e.g. $11^{\circ} 45^{\prime} \mathrm{N}$ and $16^{\circ} 20^{\prime} \mathrm{N}$; Fig. 2; Scheirer \& Macdonald 1993). At most OSCs, the leading segment is the shallower and broader segment, as also observed at EPR TFs (Carbotte et al. 2004).

Third-order discontinuities and segments. The third-order segmentation of the EPR is defined by discontinuities that offset the ridge axis by less than $c .2 \mathrm{~km}$ (Table 1). These discontinuities take a variety of forms including small OSCs, steps in the axial summit trough with lateral offsets of $0.5-2 \mathrm{~km}$, or small bends in the orientation of the axis (Figs 2 \& 3; Langmuir et al. 1986; Macdonald et al. 1988, 1992; White et al. 2006). These discontinuities may persist for tens to hundreds of thousand of years or more, as evident in subtle disruptions in the continuity of seafloor abyssal hills on the ridge flanks (Smith et al. 2001; White et al. 2002, 2006) and subdivide the ridge into segments c. $20-80 \mathrm{~km}$ long ( $30 \mathrm{~km}$ on average). The ridge axis locally deepens $(c .30-100 \mathrm{~m})$ at third-order discontinuities, and small inflections in the ridge cross-sectional area profile are observed that are smaller than those observed at second-order offsets (Figs 2 \& 4; Scheirer \& Macdonald 1993). Thirdorder offsets are not associated with increases in MBA values, suggesting no change in crustal thickness and/or density (Figs $2 \& 4$ ).

Within third-order segments, studies from both the northern and southern EPR show that low effusion-rate pillow lavas and lava domes predominate near the bounding discontinuities, and higher effusion-rate sheet flows are found within segment centres (White et al. 2000, 2002). Systematic variations are observed in other seafloor parameters including the density of hydrothermal vents and biological communities, suggesting magmatic heat sources are focused near the centre of third-order segments (Haymon \& White 2004). White et al. (2000, 2002) concluded that each third-order segment has a common crustal-level volcanic plumbing system, analogous to a 'volcanic system' in Iceland, consisting of a central volcano and associated dykes and fissures.

Recent seismic reflection observations of the EPR between the Siqueiros and Clipperton TFs reveal disruptions in the crustal magma lens coincident with third-, as well as the finer-scale fourthorder seafloor discontinuities (Carbotte et al. 2013; Marjanovic 2013; Han et al. 2014). The nature of magma lens disruptions varies, but in some locations offset and overlapping melt lenses are imaged that in plan view display a geometry similar to that of OSCs (at $9^{\circ} 36^{\prime}-39^{\prime} \mathrm{N}$, Han et al. 2014). In addition, third-order discontinuities often coincide with abrupt changes in the depth, width and presence of the AML, whereas this melt body varies over a narrower range in depth and width within individual third-order segments (Kent et al. 1993; Babcock et al. 1998; Carbotte et al. 2000; Marjanovic 2013, Fig. 2g). These observations suggest a partitioning of the crustal magmatic system on these scales, consistent with the hypothesis of White et al. $(2000,2002)$ that third-order segments are the primary volcanic segments of the EPR.

A 3D seismic tomography study of uppermost mantle structure between the Clipperton and Siqueiros TFs reveals pinches and swells in the plan view distribution of low seismic velocities attributed to pooled mantle melts within the shallowest mantle (Toomey et al. 2007). Local zones of lower seismic velocity (by 3-4\%) attributed to higher melt contents are spaced roughly coincident with the third-order segmentation of the ridge. These tomography results indicate that discrete mantle melt reservoirs underlie third-order segments along the EPR. In addition, reflection images of seismic Moho from the EPR at $9^{\circ} 42^{\prime} \mathrm{N}-9^{\circ} 57^{\prime} \mathrm{N}$ indicate changes in the nature of reflection Moho 
(a)

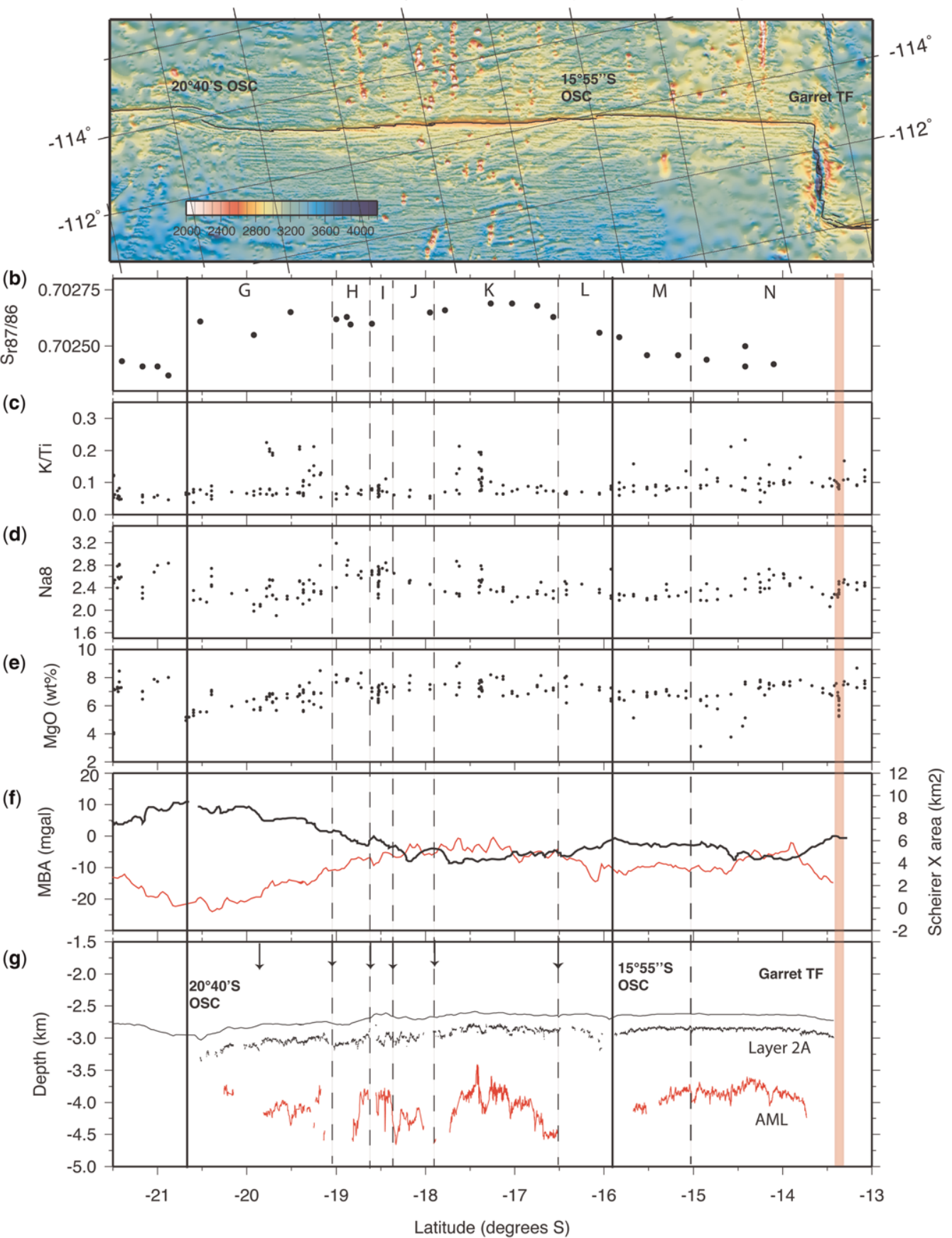

Fig. 4. Variations in ridge properties along the fast-spreading southern EPR. (a) Seafloor bathymetry for the EPR from $13^{\circ}$ to $21^{\circ} 30^{\prime} \mathrm{S}$ from the GMRT synthesis (Ryan et al. 2009). First- and second-order discontinuities are labelled. In panels below, shaded vertical bar show the locations of transform faults. Bold vertical lines mark the locations of second-order discontinuities and light dashed lines mark locations of geochemically significant third- and fourthorder discontinuities (from Sinton et al. 1991). (b-e) Geochemical data, renormalized and culled as described in the caption to Figure 2; data sources are from the PetDB synthesis database (primarily from Mahoney et al. (1994) and 


\section{SEGMENTATION OF MID-OCEAN RIDGES}

from one segment to the next (Aghaei et al. 2014) and further support a subcrustal source for this segmentation. The general correspondence of thirdorder tectonic segmentation with partitioning of the zone of mantle melt accumulation below the crust is inconsistent with early models that called upon large-scale redistribution of magma from regional upwelling centres beneath second-order segments of the EPR (Fig. 1). Instead the observations support more closely spaced sources of mantle melt that roughly coincide with the third-order tectonic segments.

Fourth-order discontinuities and segments. Fourthorder discontinuities identified along the EPR correspond with small steps $(<0.5 \mathrm{~km})$ or changes in the trend of the narrow axial summit trough or ridges of pillow lava that mark the locus of active fissure eruptions along the ridge axis (Table 1, Fig. 3c). Due to the subtle seafloor expression of these offsets and limitations in coverage and navigation of older seafloor mapping data, interpretation of these smallest discontinuities has evolved as mapping data have improved (e.g. Haymon et al. 1991; Macdonald et al. 1992; White et al. 2002, 2006). These discontinuities are now best identified along the northern EPR from $8^{\circ} 24^{\prime} \mathrm{N}$ to $11^{\circ} 45^{\prime} \mathrm{N}$ (White et al. 2006; Soule et al. 2009) where they are associated with small $(<30 \mathrm{~m})$ local deep points along the axis. Fourth-order offsets are not associated with anomalies in the axial MBA or with changes in the cross-sectional area of the ridge as measured in regional-scale bathymetry studies (Scheirer \& Macdonald 1993). However, they often coincide with breaks and local deep points (on the order of $50 \mathrm{~m}$ ) in the AML and are attributed to fine-scale $(5-15 \mathrm{~km})$ segmentation of this melt reservoir (Carbotte et al. 2000, 2013; Marjanovic 2013).

Fourth-order discontinuities have also been found to be boundaries separating segments with distinct properties of the eruptive fissure zone. For example, the depth and width of the narrow axial summit trough often change at fourth-order offsets (Macdonald \& Fox 1988; Haymon et al. 1991). Variations in the dimensions of this structure are interpreted to reflect changes in the history of eruptions and lava effusion rate from one fourth-order segment to the next, with a wider axial summit trough in regions of less frequent eruptions where ongoing dyking without eruption widens this depression (Fornari et al. 1998; Soule et al. 2009). These observations support the notion that fourthorder segments are fed by discrete magma reservoirs within the crust each with its own history of eruption and replenishment.

Variations in crustal and uppermost mantle structure associated with fine-scale segmentation was investigated in an early seismic tomography study focused on a small segment bounded by the third-order discontinuity at the EPR $c .9^{\circ} 36^{\prime} \mathrm{N}$ and what was thought at the time to be a smaller offset at $9^{\circ} 28^{\prime} \mathrm{N}$ (Toomey et al. 1990; Dunn et al. 2000). This study found that the zone of low seismic velocities in the mid-lower crust, attributed to higher melt fractions and warmer temperatures, narrows beneath both of these regions. The findings of this study have been used to argue that the finest (fourthorder) scales of seafloor segmentation are related to closely spaced sites of melt injection from the mantle. It is important to note, however, that the results of this tomography study are equivocal. The discontinuity interpreted at $9^{\circ} 28^{\prime} \mathrm{N}$ is not evident in modern GPS navigation bathymetry data from the region (e.g. White et al. 2002; 2006) or in the crustal magma lens (Detrick et al. 1987; Kent et al. 1993; Carbotte et al. 2013), and the apparent pinching of the axial low velocity zone evident in the seismic tomography study occurs near the edge of the survey box where resolution is limited (Dunn et al. 2000). Furthermore, the geometry of the region of low velocities and presumed high melt content within the uppermost mantle resolved in this study is inconsistent with that found in the recent, more comprehensive, regional study of Toomey et al. (2007). The modern tomography study indicates segmentation of mantle melt on the larger third-order scale, not the smaller scales interpreted from this early study.

\section{Geochemical properties at discontinuities and along ridge segments}

Relationships between geochemical and tectonic segmentation along fast- and superfast-spreading ridges have been explored in a number of studies (e.g. Bender et al. 1984; Thompson et al. 1985; Langmuir et al. 1986; Sinton et al. 1991; Mahoney et al. 1994; Perfit et al. 1994; Batiza 1996; Perfit \& Chadwick 1998; Castillo et al. 2000; White et al.

Fig. 4. (Continued) Sinton et al. (1991); see www.petdb.org for full references). Geochemically defined segments G-N from Sinton et al. (1991) are labelled in (b). (f) Mantle Bouguer Anomaly (black line) (Cormier et al. 1995; Magde \& Detrick 1995). Light line shows ridge cross-sectional area from Scheirer \& Macdonald (1993). (g) Cross-sections along the axis showing seafloor depth from multibeam bathymetry data and the base of layer $2 \mathrm{~A}$, and the AML imaged in multi-channel seismic data (Hooft et al. 1997). Short vertical arrows mark locations of third-order discontinuities from Scheirer et al. (1996). 


\section{S. M. CARBOTTE ET AL.}

2000, 2002; Smith et al. 2001; Sims et al. 2002). Below we summarize key geochemical findings along the northern and southern EPR (Figs $2 \& 4$ ).

Transform fault-bounded and second-order nontransform segmentation. Accumulating geochemical data suggest that along fast-spreading ridges, TFs and second-order discontinuities (large OSCs) share many of the same chemical systematics (Langmuir et al. 1986). We therefore summarize these observations together.

Chemical indicators of extents of melting, such as $\mathrm{Na}_{8.0}$ (wt\% $\mathrm{Na}_{2} \mathrm{O}$ corrected for fractionation; Klein \& Langmuir 1987), along fast-spreading ridges commonly show gradual, modest along-axis undulations over hundreds of kilometres (as do indicators of pressures of melting). Based on present sampling of the northern EPR, average $\mathrm{Na}_{8.0}$ appears to vary relatively smoothly from south of the Siqueiros TF to the $11^{\circ} 45^{\prime} \mathrm{N}$ OSC, while crossing both the $9^{\circ} \mathrm{N}$ OSC and the Clipperton TF (Fig. $2 \mathrm{~d})$. While source heterogeneity has been shown to produce local chemical variability along the EPR (e.g. Langmuir et al. 1992), the observation of longwavelength average $\mathrm{Na}_{8.0}$ variations along lengths of the EPR where $\mathrm{K} / \mathrm{Ti}$ is relatively constant (e.g. north and south of Clipperton TF) suggests that mantle temperature may vary gradually (although modestly) over these spatial scales, leading to gradual variations in average extents of melting along axis. This argues against an earlier suggestion, based on limited sampling adjacent to the Tamayo TF on the northern EPR, that basalts erupted near transforms in general are produced by smaller extents of melting due to a cold edge effect (Bender et al. 1984). Superimposed on these long-wavelength variations in extents of melting are local perturbations often associated with offsets. At the $11^{\circ} 45^{\prime} \mathrm{N}$ OSC, for example, there is an abrupt change in $\mathrm{Na}_{8.0}$, suggesting that magmas north of the OSC are produced by greater extents of melting (lower $\mathrm{Na}_{8.0}$ ) than those to the south (Fig. 2d).

With respect to source composition, in places along the northern and southern EPR where abrupt changes in isotopic or incompatible trace element ratios occur, these changes are often associated with TFs or large-offset OSCs. Across the Orozco $\mathrm{TF}$, for example, $\mathrm{K} / \mathrm{Ti}$ ratios change abruptly at relatively constant $\mathrm{MgO}$ wt\% (Fig. 2c), indicating derivation from distinct mantle sources across the offset (Donnelly 2002). A similarly abrupt change in $\mathrm{Sr}$ isotopic composition occurs across the $20^{\circ} 40^{\prime}$ S OSC (Mahoney et al. 1994, Fig. 4b). However, not all TFs or large-offset OSCs coincide with significant changes in source composition (e.g. Clipperton and Garret TF; Figs 2, 4). Overall, the observation of long-wavelength gradients in isotopic composition (Fig. 4b) and both the presence and absence of abrupt changes in source composition at TFs and second-order discontinuities argues against the early notion that ridge segments bounded by these discontinuities in general represent coherent geochemical units derived from a common source composition (e.g. Langmuir \& Bender 1984).

Superimposed on variations in source composition and melting conditions are the often prominent along-strike changes in extent of crystal fractionation. Abrupt changes in $\mathrm{MgO} \mathrm{wt} \%$, a measure of magma temperature and extent of crystallization, occur across the Clipperton and Orozco TFs, and the $9^{\circ} \mathrm{N}$ and $20^{\circ} 40^{\prime} \mathrm{S}$ OSCs (Figs 2e \& 4c). Such changes in extent of fractionation have been attributed to variations in the balance between magma supply and cooling rate (e.g. Christie \& Sinton 1981). Little change in fractionation, however, is observed across the Garrett TF or the $16^{\circ} 20^{\prime} \mathrm{N}$ OSC. The relatively primitive nature of lavas on either side of the Garret TF argues against the suggestion that magmas erupted near transforms are typically more fractionated (e.g. Bender et al. 1984). Interestingly, however, at some second-order offsets, significant extents of crystallization have been observed, most notably at the $9^{\circ} \mathrm{N}$ OSC, where highly fractionated (low $\mathrm{MgO}$ wt $\%$ ) magmas are sampled (Fig. 2e) (Wanless et al. 2010; Klein et al. 2013).

Third-order discontinuities and segments. Characterization of geochemical systematics associated with third-order (and fourth-order) discontinuities requires fine-scale sampling and good spatial control. Based on samples recovered at an average spacing of $c .8 \mathrm{~km}$ along the EPR from $5.5^{\circ} \mathrm{N}$ to $14.5^{\circ} \mathrm{N}$, Langmuir et al. (1986) identified significant chemical variability associated with even small ridge offsets, most of which are now classified as third-order offsets (White et al. 2006). Further, they raised the possibility that the ridge segments in between these offsets may exhibit coherent chemical systematics distinct from adjacent segments, although the sampling density in their study was insufficient to fully explore this question.

Sinton et al. (1991) identified similar chemical variability associated with small ridge offsets along the southern EPR from $13-23^{\circ} \mathrm{S}$ (Fig. 4), and demarcated lengths of ridge (averaging $c .69 \mathrm{~km}$ ) that appear to have common parental magma compositions likely resulting from similar melting conditions. They described these lengths of ridge as 'secondary magmatic segments' (labelled G-N in Fig. 4b) to distinguish them from their 'primary magmatic segments' based on isotopic composition. The boundaries of these segments correspond primarily with third-order offsets (mostly small OSCs), in addition to the Garret TF and two second-order 


\section{SEGMENTATION OF MID-OCEAN RIDGES}

offsets. Sinton et al. (1991) suggested further that these findings could be used to place constraints on the along-axis spacing of mantle melt segregation events. They argued that the spacing of injection centres could be less than the lengths of the geochemically defined segments (e.g. if two adjacent injection centres happen to produce similar parental magma compositions), but they cannot be greater.

Few studies have collected lavas at sufficient sampling density to explore geochemical variations at individual third-order offsets and adjacent segments in detail. In a study of the third-order discontinuity at $9^{\circ} 37^{\prime} \mathrm{N}$ on the EPR (Figs $2 \& 3$ ), Smith et al. (2001) showed that the southward-propagating east limb of this discontinuity erupts primitive lavas of relatively uniform composition, while the west limb erupts lavas that are both more fractionated and more variable in parental magma composition, suggesting less efficient magma mixing beneath the western dying limb. These findings support the idea that the segments adjacent to these third-order offsets may have isolated magma plumbing systems fed by compositionally variable melts (e.g. Langmuir et al. 1986; Reynolds et al. 1992; Perfit et al. 1994; Smith et al. 2001; White et al. 2002; Bergmanis et al. 2007).

Fourth-order discontinuities and segments. In one of the few studies of sufficient sampling density to explore detailed geochemical systematics associated with fourth-order offsets, Goss et al. (2010) report subtle differences in the compositions of lavas sampled along the fourth-order segments north and south of the $9^{\circ} 53^{\prime} \mathrm{N}$ deval resulting from differences in extents of melting and fractionation. Carbotte et al. (2013) showed that the boundaries between these small-scale geochemical and tectonic segments in this region correlate with disruptions in the continuity and characteristics of the underlying melt lens. Based on these relationships, they argued that the fourth-order tectonic segmentation is inherited from partitioning of the crustal magma lens, and that the chemical differences along adjacent segments result from dominantly vertical transport of melt from these chemically distinct melt lens segments.

\section{Intermediate spreading ridges}

Intermediate spreading centres spread at rates from c. 50 to $80 \mathrm{~mm} \mathrm{a}^{-1}$ (DeMets et al. 1994) and include the Galapagos Spreading Centre (GSC), the Juan de Fuca (JdF) and Gorda Ridges, the Chile Rise, the SEIR and portions of the Pacific-Antarctic Ridge. Here we focus primarily on observations from the SEIR $100-111^{\circ} \mathrm{E}$ (Figs 5 \& 6) and the western GSC $98-91^{\circ} \mathrm{W}$ (Fig. 7), two well-studied regions where the range of typical intermediate spreading ridge structure is found.

While the morphology of intermediate spreading ridges varies widely from the axial highs characteristic of fast-spreading ridges to the $>1 \mathrm{~km}$-deep rift valleys typical of slow-spreading ridges (e.g. Small 1998), the most common morphological types are rifted axial highs and shallow rift valleys (Fig. 6, Cochran \& Sempéré 1997; Goff et al. 1997; Sempéré et al. 1997; Small et al. 1999; Sinton et al. 2003; Christie et al. 2005). Rifted axial highs are characterized by a narrow depression 50-200 m deep at the summit of an axial high that is a few kilometres wide (Fig. 6c, segment P3). Shallow valleys are typically $2-4 \mathrm{~km}$ wide and $<400 \mathrm{~m}$ deep (Fig. $6 \mathrm{a}$, segment S1). Abrupt changes in the morphology of the ridge axis from axial highs to shallow rifts are an important characteristic of intermediate spreading ridges and are observed within both the SEIR and GSC study regions. These abrupt transitions are believed to result from a threshold response of the ridge to small changes in magma supply: as magma supply decreases below a certain threshold, the reservoir of magma in the crust rapidly disappears, leading to a large increase in the thickness/ strength of the axial lithosphere, which in turn controls the nature of axial topography (Phipps Morgan \& Chen 1993; Cochran \& Sempéré 1997). Along many intermediate spreading ridges, regional gradients in ridge properties are observed that extend over hundreds to thousands of kilometres and are attributed to gradual variations in magma supply with proximity to local hotspots (e.g. the Galapagos hotspot near the GSC; Schilling et al. 1982) or coldspots such as AAD along the SEIR (Klein et al. 1991; West et al. 1994; Christie et al. 1998). In addition to these regional gradients, 'tectonic corridors' have been identified from systematic differences in the rate and asymmetry of across-axis seafloor subsidence with age that span multiple TF-bounded segments (Hayes \& Kane 1994). Along the SEIR, five tectonic corridors with average lengths of $800 \mathrm{~km}$ are identified, one of which extends from $100^{\circ}-115^{\circ} \mathrm{E}$ and includes the area of Figure 5.

\section{Geophysical properties of discontinuities and ridge segments}

Transform faults and first-order segments. The SEIR is offset by numerous long-lived TFs that range in length from 37 to $130 \mathrm{~km}$ and subdivide the ridge into segments $55-700 \mathrm{~km}$ long (Small 1998; Table 1). The ridge axis typically deepens by several $100 \mathrm{~m}$ within a few kilometres of these TFs, and axial MBA values are typically 5-10 $\mathrm{mGal}$ higher (Fig. 5g, f; Cochran \& Sempéré 1997). Seismic studies indicate the crust is slightly thinner 
(a)
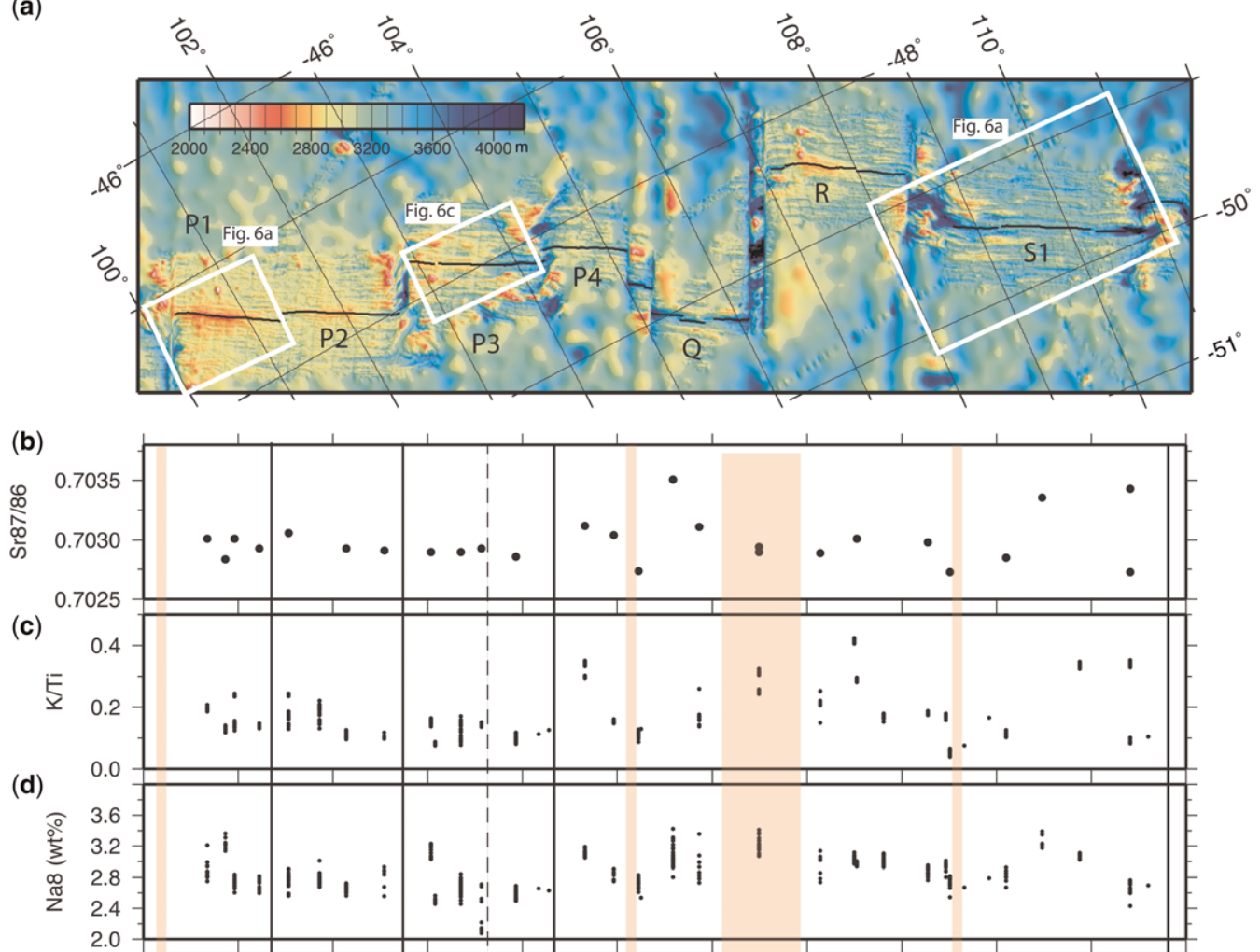

(e)

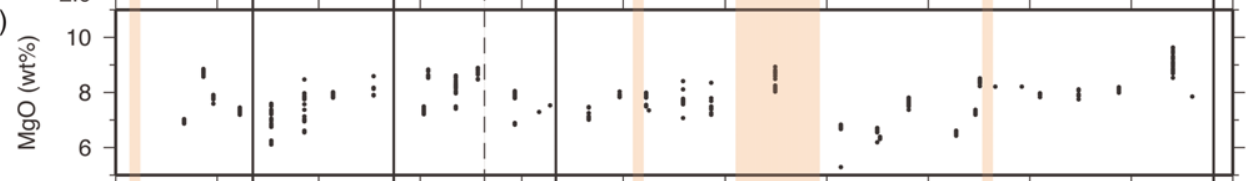

(f)
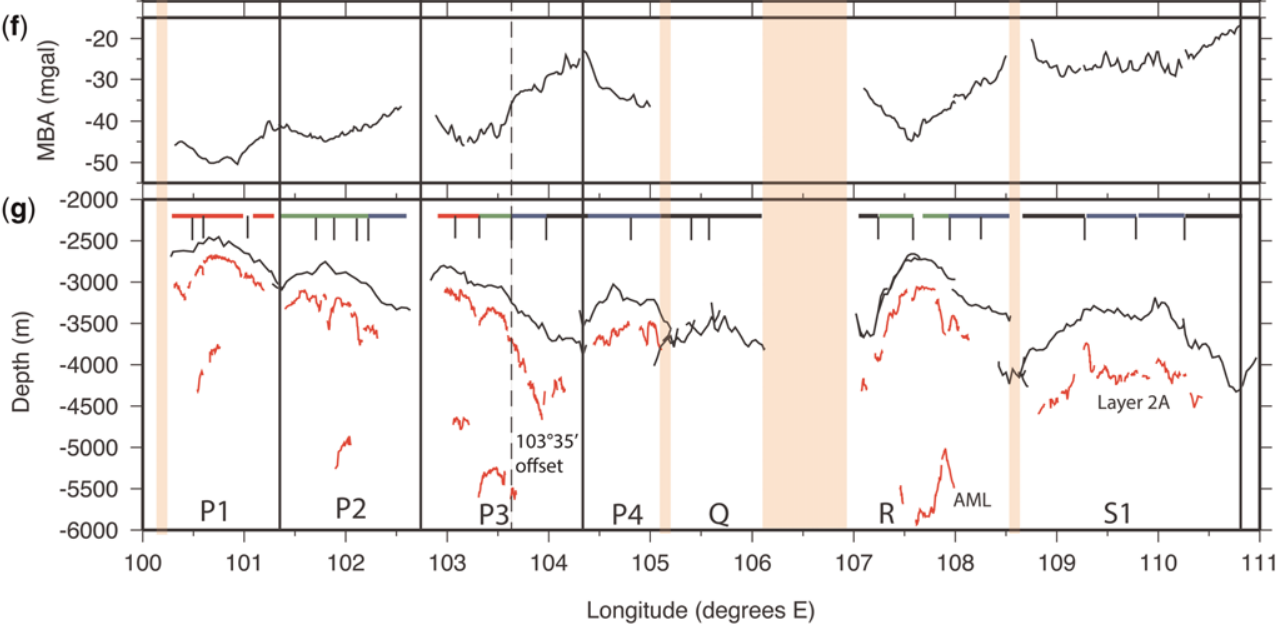

Fig. 5. Variations in ridge properties along the intermediate spreading South East Indian Ridge (SEIR). (a) Seafloor bathymetry of the SEIR from $100^{\circ} \mathrm{E}$ to $111^{\circ} \mathrm{E}$ from Baran et al. (2005) and the GMRT synthesis (Ryan et al. 2009). Second-order segments P1 through S1 are labelled. In panels below, shaded vertical bars show the locations of transform faults. Bold vertical lines mark the locations of OSC discontinuities. (b-e) Geochemical data, as in Figures 2 and 4, from PetDB. (f) Mantle Bouguer Anomaly measured along axis from Cochran \& Sempéré (1997). (g) Cross-section 


\section{SEGMENTATION OF MID-OCEAN RIDGES}

$(<0.5 \mathrm{~km})$ near TFs (Holmes et al. 2008). In general, the local anomalies in ridge properties near TFs are similar in magnitude to those observed at the second-order discontinuities along this ridge. The depth of the ridge axis along the SEIR within the region of Figure 5 is dominated by longwavelength deepening toward the AAD to the east. Superimposed on this regional gradient are steps in the depth of the ridge axis at TFs. As observed at fast-spreading ridges, there is a marked asymmetry in the depth of the two adjoining ridge segments across TFs, with the leading segment consistently shallower than the trailing segment (Carbotte et al. 2004).

In marked contrast to the SEIR, few TFs are found along the hotspot-dominated GSC. Indeed, the Galapagos TF located at $c .90^{\circ} 45^{\prime} \mathrm{W}$ is the only transform offset for over $1500 \mathrm{~km}$ along the GSC from the western tip of the GSC to the Inca TF at $85^{\circ} 30^{\prime} \mathrm{W}$.

Second-order discontinuities and segments. The large non-transform or second-order offsets found along intermediate spreading ridges display a wide range of morphological types (Cochran \& Sempéré 1997; Goff et al. 1997; Sempéré et al. 1997; Small et al. 1999; Sinton et al. 2003; Christie et al. 2005). In some cases, overlapping shallow rifts or axial ridges are observed that curve toward each other enclosing an elliptical overlap basin (e.g. $93^{\circ} 15^{\prime} \mathrm{W}$ on the GSC; Sinton et al. 2003; Fig. 7) or a local topographic high (e.g. the P3-P4 offset at $104^{\circ} 20^{\prime} \mathrm{E}$ on the SEIR; Baran et al. 2005). At other discontinuities the offset ridges or rifts do not overlap but exhibit an oblique jog in the axial zone or a region of locally deeper seafloor cross-cut by faults that are highly oblique to the ridge axis trend (e.g. the PR at $95^{\circ} 30^{\prime} \mathrm{W}$ on the GSC; Fig. 7). Transitional discontinuities are also observed such as the $c .30 \mathrm{~km}$ offset at $102^{\circ} 50^{\prime} \mathrm{E}$ on the SEIR. Here a narrow ridge-perpendicular transform fault zone is present, but on the ridge flanks there is a broad zone of disturbed and oblique-trending topography without a ridge-perpendicular fracture zone (Fig. 5a), indicating the TF has developed only recently.

Along the SEIR, second-order segments are typically 60-80 km long (Sempéré et al. 1997; Fig. 5). Many display arch-shaped along-axis depth profiles, with variations of a few hundred metres to a kilometre from segment ends to shallow points, which are located either within the centres or offset to the western ends of these segments. Gravity variations within these segments mirror the variations observed in depth, with axial MBA lows of c. 10-20 mGal centred over the shallowest portions of many, but not all, segments (P1, P2, P3 and R; Fig. 5f; Cochran \& Sempéré 1997). These segment-scale MBA variations are attributed to the focusing of mantle melt beneath these shallower regions (Cochran \& Sempéré 1997). Multi-channel seismic studies reveal an axial magma body in the crust that is only detected beneath the central shallow portions of these same segments (Fig. $5 \mathrm{~g}$; Baran et al. 2005), supporting the hypothesis that mantle melt supply is focused beneath these regions. Properties of this magma body, including its average depth and width, as well as the average thickness of the volcanic layer of the crust inferred from observations of seismic layer $2 \mathrm{~A}$, vary from one ridge segment to the next (e.g. average AML depth is $1480 \mathrm{~m}$ at $\mathrm{P} 1$ and $2100 \mathrm{~m}$ at P2; average layer 2a thickness is $310 \mathrm{~m}$ at P1 and $460 \mathrm{~m}$ at P2; Baran et al. 2005), consistent with the notion that a separate melt supply system underlies each segment. The seismic data also suggest that second-order segments can be further subdivided. For example, within segment P3 a break in the continuity of the magma body coincides with a small ridge offset at $103^{\circ} 20^{\prime} \mathrm{E}$ (see below; Fig. $5 \mathrm{~g}$ ) along with a change in average depth of the body from $1900 \mathrm{~m}$ to $2320 \mathrm{~m}$ and in the thickness of layer 2A (from $370 \mathrm{~m}$ to $740 \mathrm{~m}$ ), suggesting that two separate magmatic systems underlie this second-order segment.

Seismic measurements of crustal thickness are available for segments P1, P2 and S1 of the SEIR (see Fig. 5 for location; Holmes et al. 2008). These data indicate slightly thinner crust $(<0.5 \mathrm{~km})$ near the discontinuities that bound these segments. However, overall crustal thickness variations found along this intermediate spreading ridge are minor $(<1 \mathrm{~km})$. Hence, although there is good evidence for melt focusing beneath these second-order segments, the crust formed is quite uniform in thickness along the length of the segment.

Along the GSC, second-order segments are 100 to $>200 \mathrm{~km}$ long (Sinton et al. 2003; Christie et al. 2005), considerably longer than along the SEIR and more similar to the lengths of secondorder segments on the EPR. Variations in ridge properties within these second-order segments are also more subdued than along the SEIR and are

Fig. 5. (Continued) along the axis showing seafloor depth from multibeam bathymetry data, and the base of layer $2 \mathrm{~A}$ and the AML imaged in multi-channel seismic data from Baran et al. (2005). Horizontal bar at top of panel indicates type of axial morphology: (colours in online version of the figure) red, axial high; green, rifted high; blue, shallow rift valley; black, rift valley. The locations of small-scale (third-order) discontinuities found along the axis are indicated with short vertical lines. 
(a)
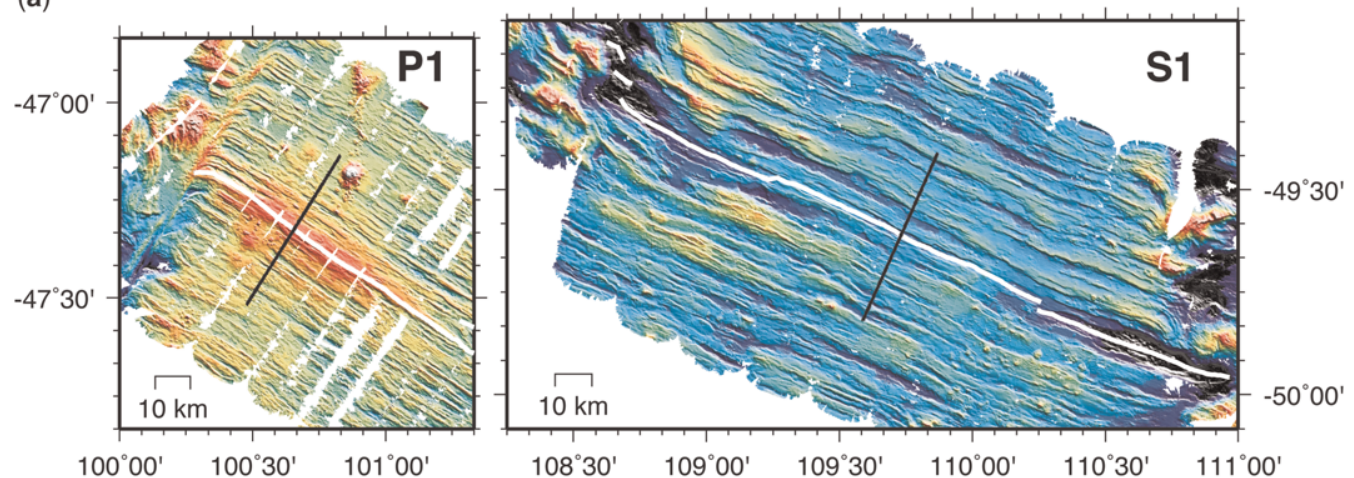

(b)

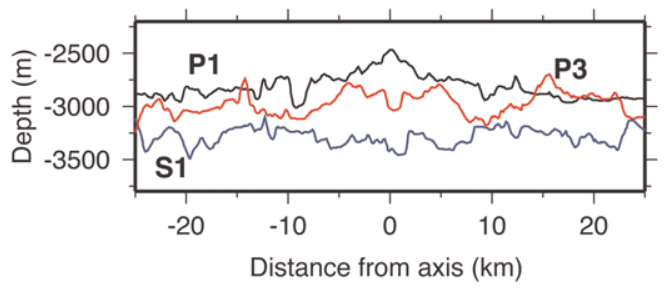

(c)

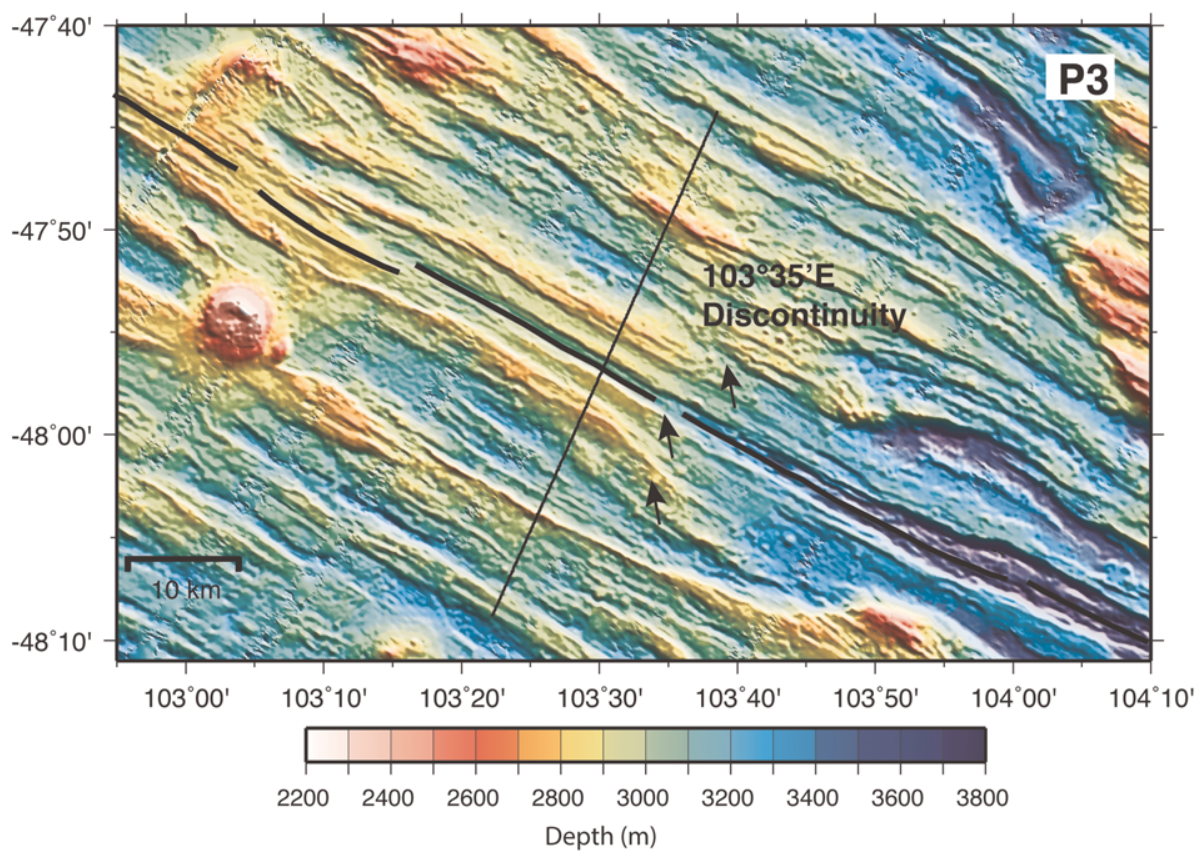

Fig. 6. Bathymetric maps illustrating axial morphology of a magma-rich and magma-poor segment and fine-scale segmentation along the SEIR (full spreading rate $76 \mathrm{~mm} \mathrm{a}^{-1}$ ). (a) Panels show the magma-rich P1 (left) and magma-poor S1 (right) segments of the SEIR. Thin black lines show location of ridge axis. Bold black lines show location of cross-axis profiles shown in (b). (b) Although spreading rates are approximately constant throughout this region, the P1 segment (profile 1) is associated with a broad shallow axial high, while at the S1 segment (profile 2) a shallow axial valley is present. (c) Close up of the P3 segment of the SEIR showing the small $103^{\circ} 35^{\prime} \mathrm{E}$ discontinuity that marks the regional transition from predominantly rifted axial high topography to the west to shallow rift valley topography to the east. Bathymetric data are from the GMRT synthesis (Ryan et al. 2009). 


\section{SEGMENTATION OF MID-OCEAN RIDGES}

dominated by regional gradients associated with the Galapagos hotspot (compare Figs $5 \& 7$ ). East of $c$. $98^{\circ} \mathrm{W}$, seafloor gradually shoals (Fig. $7 \mathrm{~h}$ ) and axial MBA values gradually decrease by $>60 \mathrm{mGals}$ (Fig. 7f; Canales et al. 2002) suggesting thicker crust and/or warmer temperatures toward the Galapagos hotspot. These regional gradients are interrupted at some second-order discontinuities $\left(95^{\circ} 30^{\prime} \mathrm{W}\right.$ and $\left.96^{\circ} 30^{\prime} \mathrm{W}\right)$. Within $5-20 \mathrm{~km}$ from these offsets the ridge axis locally deepens by 100 $300 \mathrm{~m}$, and local gravity highs of 5-15 mGal are observed. However, no local MBA high is associated with the $93^{\circ} 15^{\prime} \mathrm{W}$ OSC (Fig. 7f).

From the available seismic data, there is no evidence for locally thinner crust at second-order offsets along the GSC (Fig. 7e; Canales et al. 2002). Rather, crustal thickness increases gradually toward the hotspot, consistent with inferences from gravity data. MCS data have been acquired along the ridge axis from $c .95^{\circ} \mathrm{W}$ to $91^{\circ} 20^{\prime} \mathrm{W}$ and reveal a crustal magma body beneath most of the ridge axis east of $94^{\circ} 20^{\prime} \mathrm{W}$ (Fig. $7 \mathrm{~g}$; Detrick et al. 2002; Blacic et al. 2004). Although there is a $15 \mathrm{~km}$-long break in the continuity of the AML at the $93^{\circ} 15^{\prime} \mathrm{W}$ OSC, this discontinuity is not a significant boundary in magma lens properties as might be expected if regional upwelling centres fed the adjoining second-order segments. Notably, a major change in the depth and width of the AML coincides with a much smaller offset at $92^{\circ} 40^{\prime} \mathrm{W}$ (see below) and not the second-order $93^{\circ} 15^{\prime} \mathrm{W}$ discontinuity (Fig. 7g; Blacic et al. 2004).

Third-order discontinuities and segments. Along intermediate spreading ridges, a class of small offsets is found that are analogous to the third- and possibly fourth-order offsets recognized along the EPR. At the GSC, these small discontinuities correspond with offsets of typically $<2 \mathrm{~km}$ or bends in the orientation of the axis of $>5^{\circ}$ (Fig. 7; Sinton et al. 2003; Christie et al. 2005; White et al. 2008). Similar small-scale offsets are observed along the SEIR (Fig. 6) with interpreted locations indicated in Figure 5. Some of these small discontinuities appear to have an identifiable trace on the near-ridge flanks indicating they have persisted at these locations for $10^{5}$ years or more (e.g. $103^{\circ} 35^{\prime} \mathrm{E}$; Fig. 6), whereas others do not have a trace on the near-ridge flanks and appear to be shorter lived. However, whether there are nested scales of fine-scale segmentation like those on the EPR, with longer-lived third-order segments subdivided into shorter-lived segments, has not been established and these offsets are considered here as one class (Table 1).

At the GSC, these small offsets define morphological segments $30 \mathrm{~km}$ to $>100 \mathrm{~km}$ long that are interpreted as the primary volcanic segments along this ridge (Sinton et al. 2003; Christie et al. 2005;
White et al. 2008). The available seismic data from the western GSC show breaks in continuity and changes in the depth of the AML at several of these small offsets $\left(93^{\circ} 53^{\prime} \mathrm{W}, 92^{\circ} 40^{\prime} \mathrm{W}, 91^{\circ} 33^{\prime} \mathrm{W}\right.$; Fig. 7g; Detrick et al. 2002; Blacic et al. 2004), suggestive of separate magmatic systems beneath the adjacent segments. Furthermore, some of these small offsets also mark major regional boundaries in other ridge properties. For example, the transition in the morphology of the ridge axis from an axial high to a rifted high along the western GSC coincides with a small discontinuity at $92^{\circ} 40^{\prime} \mathrm{W}$ of only $500 \mathrm{~m}$ offset (Fig. 7; Sinton et al. 2003; White et al. 2008). An abrupt step in both the depth (0.6s twoway travel time or $c .1 .5 \mathrm{~km}$; Fig. $7 \mathrm{~g}$ ) and width (from $0.5-1.5 \mathrm{~km}$ east of $92^{\circ} 40^{\prime} \mathrm{W}$ to $0.7-2.4 \mathrm{~km}$ to the west) of the AML (Detrick et al. 2002; Blacic et al. 2004) also occurs at this discontinuity, along with a transition in the nature of seafloorvolcanic relief (Colman et al. 2012). Similarly, along the SEIR a small offset of $<200 \mathrm{~m}$ at $103^{\circ} 35^{\prime} \mathrm{E}$ coincides with an abrupt transition in ridge morphology from rifted axial highs to shallow rift valleys (Figs 5 \& 6) and a $c .10 \mathrm{mGal}$ step in the regional MBA gradient (Fig. 5g; Cochran \& Sempéré 1997).

\section{Geochemical properties of discontinuities and ridge segments}

Chemical analyses of lavas recovered from the western GSC display long-wavelength gradients in magma composition that, with geophysical and geological variables, correlate to first-order segments (Fig. 7). On the largest scale, isotopic and incompatible trace element ratios reveal a westerly decrease in source enrichment with distance from the Galapagos hotspot that correlates with decreasing crustal thickness and increasing axial depth, MBA and (where investigated) melt sill depth (Schilling et al. 1982; Detrick et al. 2002; Sinton et al. 2003) This overall geochemical trend is subdivided into three $>200 \mathrm{~km}$-long geochemical provinces reflecting changes in source enrichment ("primary magmatic segments' of Sinton et al. 1991): an enriched-mid-ocean ridge basalt (E-MORB) province east of $92^{\circ} 40^{\prime} \mathrm{W}$; a transitional (T-MORB) province between the $92^{\circ} 40^{\prime} \mathrm{W}$ third-order offset and the $95^{\circ} 30^{\prime} \mathrm{W}$ PR tip; and a normal (N-MORB) province west of $95^{\circ} 30^{\prime} \mathrm{W}$ (Fig. 7b, c, Sinton et al. 2003; Cushman et al. 2004; Ingle et al. 2010). These geochemical provinces also coincide with changes in axial morphology (eastern axial high, central transitional and western axial deep morphologies), and the $92^{\circ} 40^{\prime} \mathrm{W}$ third-order offset coincides with a rapid westward doubling of the depth to the melt lens and the base of layer 2A (Detrick et al. 2002). Notably, although the $95^{\circ} 30^{\prime} \mathrm{W}$ PR forms a boundary in terms of source composition, the 

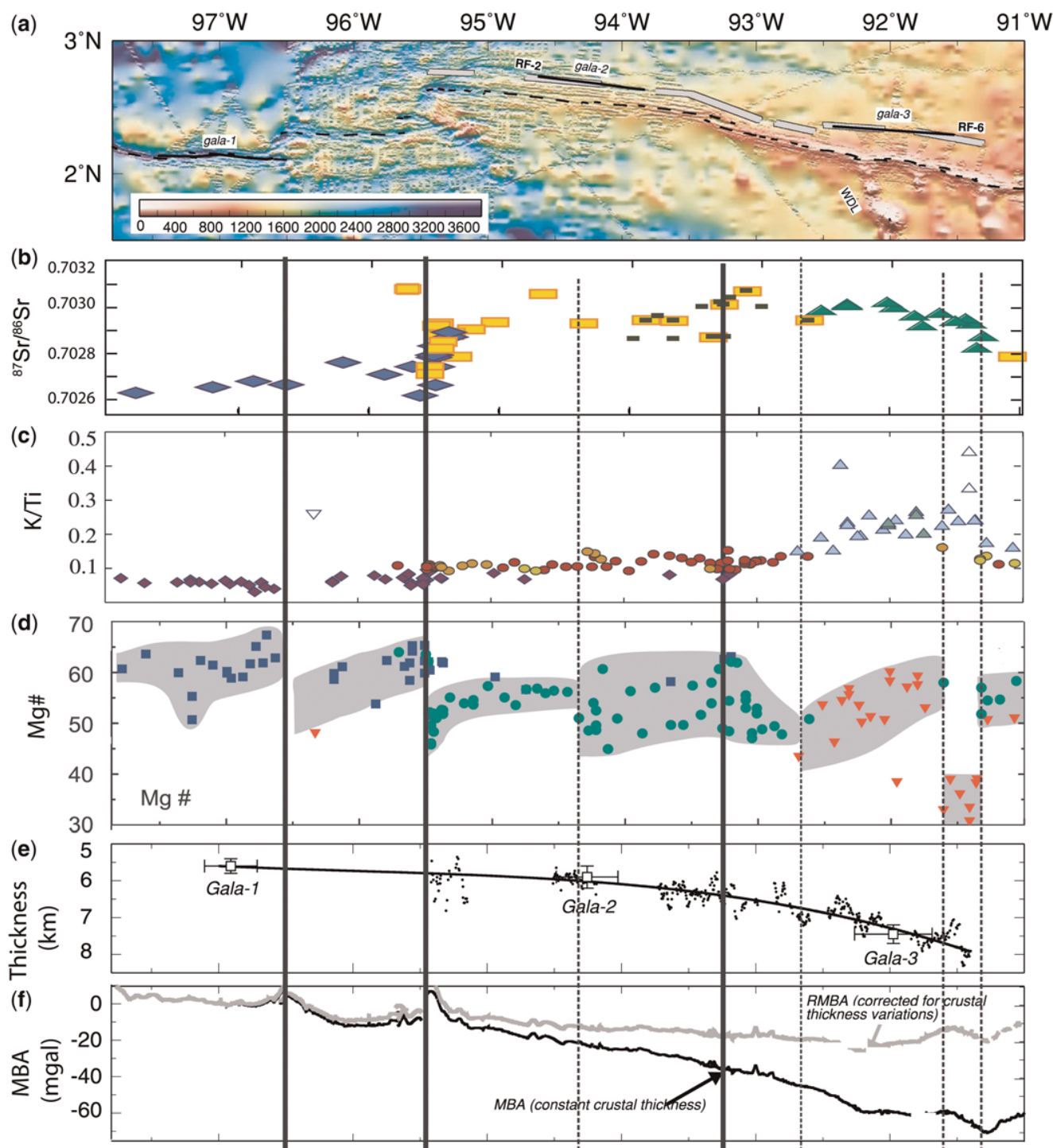

(g)

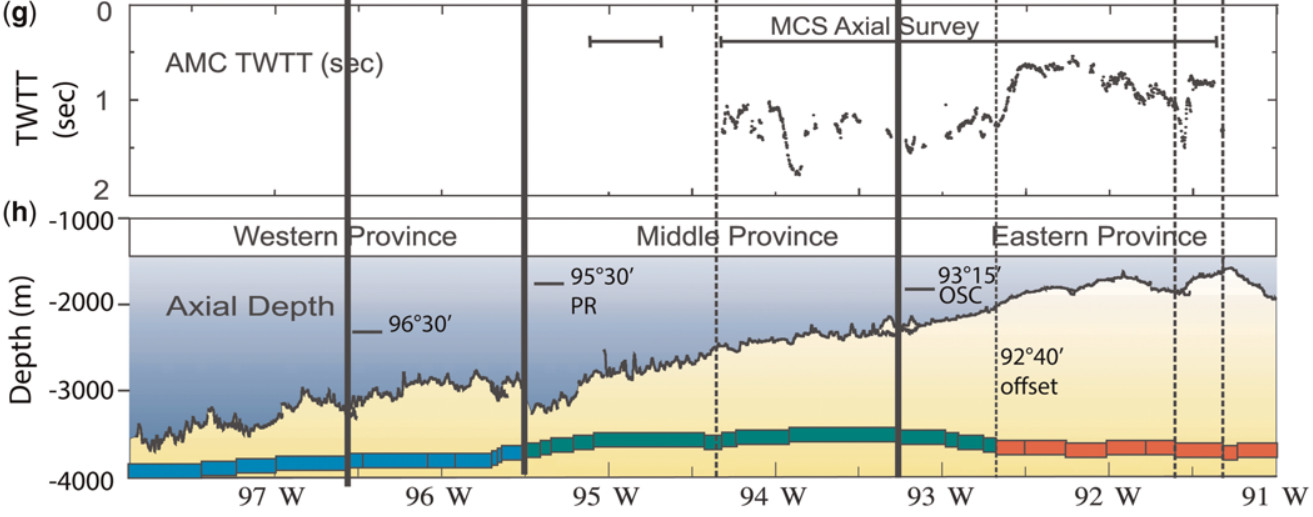

Longitude 


\section{SEGMENTATION OF MID-OCEAN RIDGES}

other second-order offset in this region at $93^{\circ} 15^{\prime} \mathrm{W}$ (variously described as a PR or OSC) does not. In this sense, the GSC appears to share some similarities with the EPR in that some, but not all, second- and third-order boundaries coincide with abrupt changes in source composition, and magma compositions along some of these segments share common source characteristics.

The strong influence of the Galapagos hotspot on the GSC lavas to $95^{\circ} 30^{\prime} \mathrm{W}$ makes it difficult to isolate chemical changes resulting from variations in extent and pressures of melting from those resulting from variations in source composition, and thus to explore whether 'secondary magmatic segments' like those described by Sinton et al. (1991) for the southern EPR can be identified along the GSC. Cushman et al. (2004) suggested that E-MORB and $\mathrm{N}-\mathrm{MORB}$ may be produced by similar mean extents of melting but that greater amounts of melt are produced near the hotspot due to hydrous melting of a greater mantle volume. They did not, however, explore the relationship between segmentation and along-axis changes in melting conditions.

The most prominent geochemical systematics associated with offsets along the GSC are variations in the extent of fractionation. Sinton et al. (2003) identified eight segments, 30-120 km in length,

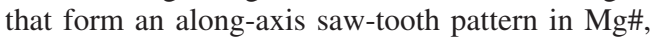
with relatively smooth variations within segments and abrupt changes across second- and some thirdorder offsets (Fig. 7d). The boundaries of these fractionation-defined segments also coincide with changes in the characteristics of the melt lens, and the variability of $\mathrm{Mg \#}$ within segments appears to correspond to variability in melt lens depth and continuity. Sinton et al. (2003) attributed the segmentation in fractionation to along-strike changes in the thermal structure of the crust. Noting the similarity of these fractionation trends to the $200 \mathrm{~km}$-long fractionation gradient approaching the $20^{\circ} 40^{\prime} \mathrm{S}$ OSC on the EPR, they speculate that the segmentation in
Mg\# along the GSC may reflect gradients in magma supply, with greatest input of magma at the eastern end of most segments (nearest the hotspot).

Despite the collection of significant geophysical data along the SEIR between $100^{\circ} \mathrm{E}$ and $111^{\circ} \mathrm{E}$ (Baran et al. 2005; Fig. 6), sampling remains sparse, allowing only general observations to be made. On a regional scale, the SEIR shows long-wavelength gradients in isotopic ratios and other chemical parameters suggesting an eastward decrease in average extents of melting and diminishing multi-source component source enrichment (Mahoney et al. 2002; Graham et al. 2006; Russo et al. 2009; Hanan et al. 2013). Within the region shown in Figure 6a, transition occurs near the P3-P4 offset with lower average $\mathrm{Na}_{8.0}$ values (indicating greater extents of melting) along segments west of the offset, where the ridge is characterized by an axial high and rifted high morphology and lower MBA values (Fig. 6). In contrast, average $\mathrm{Na}_{8.0}$ values in segments east of this boundary are higher, suggesting smaller extents of melting associated with the areas of deeper axial rift valleys and higher MBA. The limited chemical data available thus provide general support for previous work suggesting an abrupt transition in ridge properties in this region (Baran et al. 2005), and is consistent with the idea that intermediate spreading ridges display a threshold response to small changes in melt supply (Phipps Morgan \& Chen 1993; Cochran \& Sempéré 1997).

\section{Slow-spreading ridges}

Slow-spreading ridges $\left(20-50 \mathrm{~mm} \mathrm{a}^{-1}\right)$ include the MAR, Reykjanes Ridge, Central Indian Ridge and the southern Gorda Ridge. The best-studied slowspreading ridge to date is the northern MAR, and the following discussion is focused mainly on the region between $15^{\circ} \mathrm{N}$ and $40^{\circ} \mathrm{N}$, which spans five

Fig. 7. Variations in ridge properties along the intermediate spreading Galapagos Spreading Centre (GSC) from $98^{\circ} \mathrm{W}$ to $91^{\circ} \mathrm{W}$. (a) Seafloor bathymetry of the GSC with ridge axis indicated by black dashed line from Canales et al. (2003). In panels below, black vertical lines mark the locations of second-order discontinuities including overlapping spreading centres and propagators. Black dashed lines show location of smaller discontinuities identified by Sinton et al. (2003) that mark significant boundaries in other ridge properties. (b) ${ }^{87} \mathrm{Sr} /{ }^{86} \mathrm{Sr}$ from axial basalts from Ingle et al. (2010) (c) $\mathrm{K} / \mathrm{Ti}$ values from Cushman et al. (2004). (d) Variation in glass Mg\# with regions of smoothly varying Mg\# shaded. Samples are keyed to chemical affinity based on K/Ti, as follows: N-MORB (blue squares), T-MORB (green circles) and E-MORB (inverted red triangles). Figure from Detrick et al. (2002). (e) Crustal thickness estimated from seismic refraction lines (squares with uncertainty bounds) and MCS data (dots) from Canales et al. (2003). (f) Along-axis MBA and residual anomaly calculated for crustal thickness from (e), also from Canales et al. (2003). (g) TWTT to the AML reflector detected by MCS survey along axis from Blacic et al. (2004) and Detrick et al. (2002); survey was run off axis between $94^{\circ} 42^{\prime} \mathrm{W}$ and $94^{\circ} 21^{\prime} \mathrm{W}$. (h) Bathymetry, segmentation and axial morphology from Sinton et al. (2003). Axial depth profile shows water depth along the present spreading axis. Eastern, Middle and Western indicate three regional provinces identified by Sinton et al. (2003) based on axial morphology. Smaller-scale segmentation and axial morphology are shown by the coloured rectangles where red denotes axial high, green denotes transitional and blue denotes axial deep. Sense of offset (not to scale) between the smaller segments is indicated. 
(a) सू. so. ง . $x_{0}$.

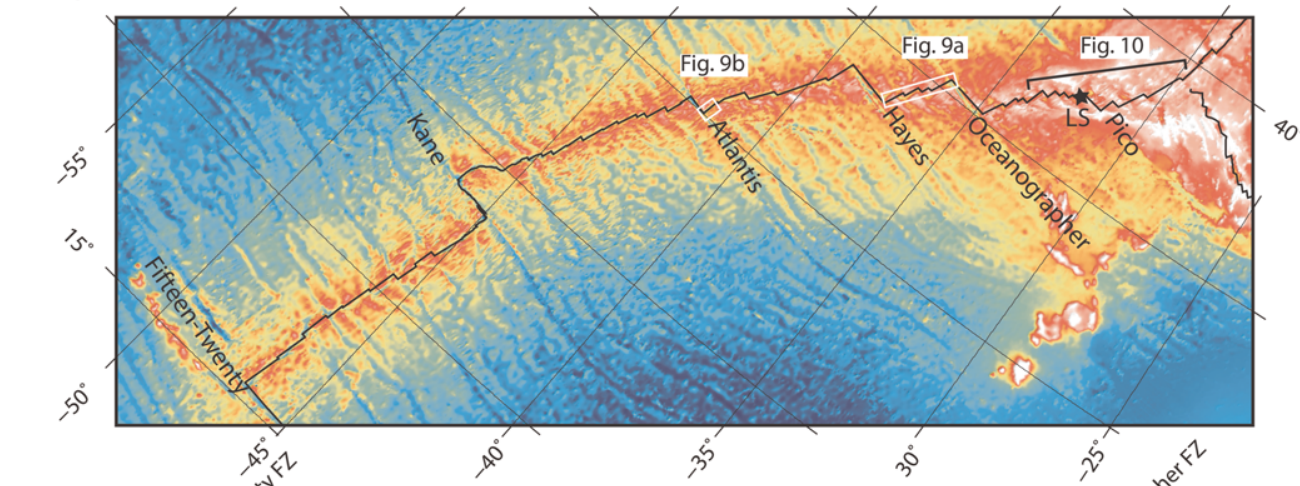

(c)

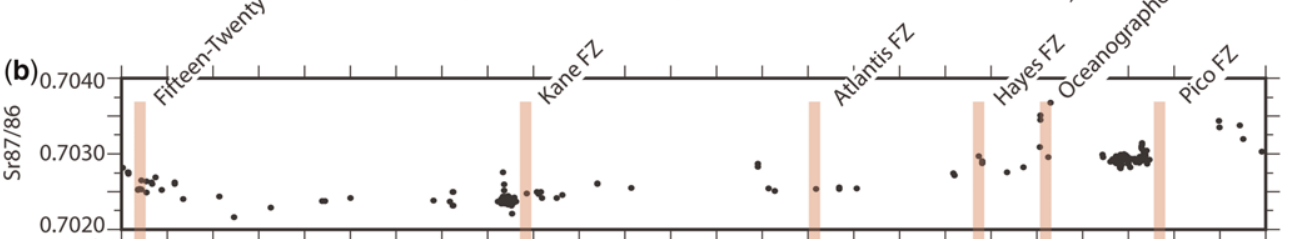

(d)
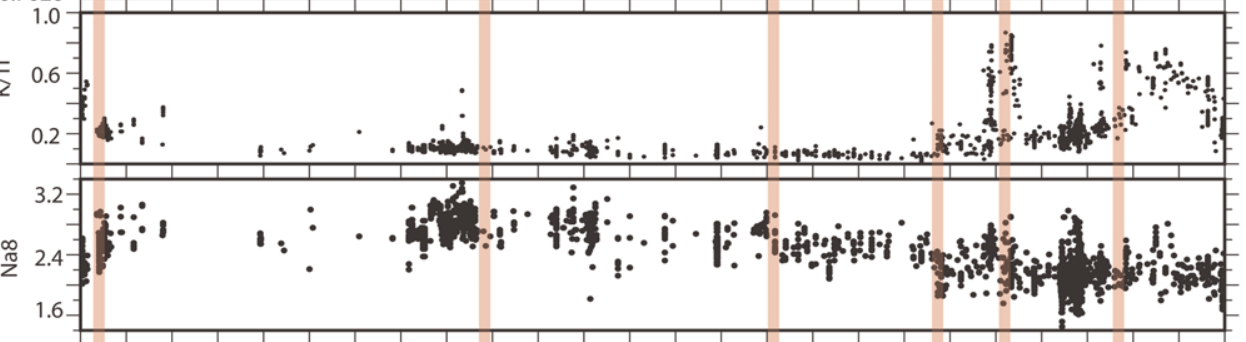

(e)

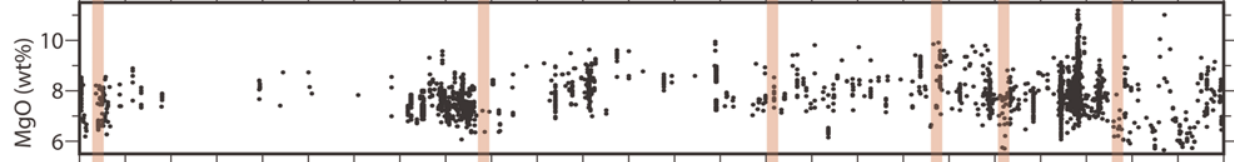

(f)

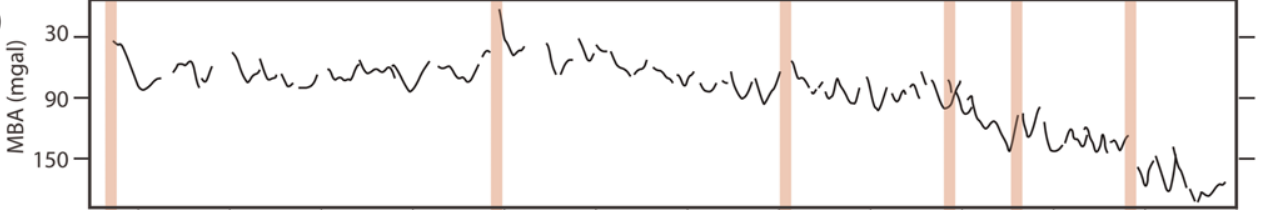

(g)

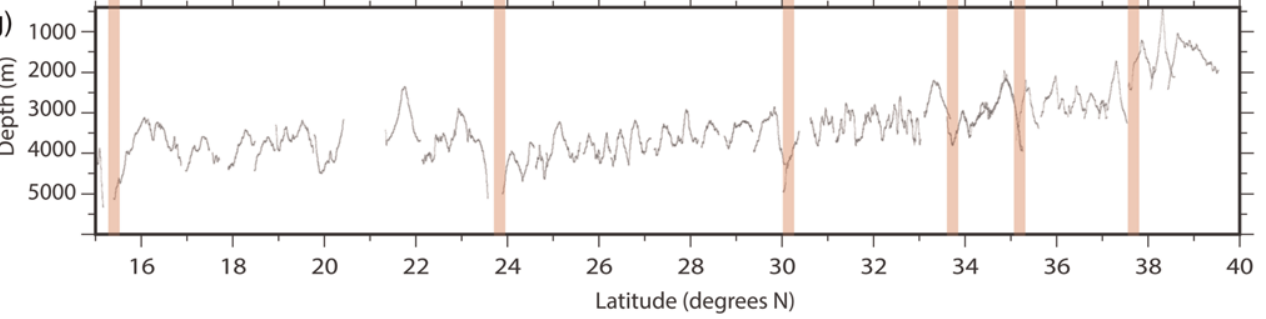

Fig. 8. Variations in ridge properties along the northern Mid-Atlantic Ridge (MAR). (a) Seafloor bathymetry for the MAR $\left(15-40^{\circ} \mathrm{N}\right)$ from the GMRT synthesis (Ryan et al. 2009). Black line marks the ridge axis and its offsets. Locations of detailed bathymetry maps in Figure 9 are shown by white rectangles. The location of the study of Gale et al. (2011) is also marked (Fig. 10). Transform faults are labelled. In the panels below, shaded vertical bars show the locations of transform faults. (b-e) Geochemical data, as in Figures 2 and 4, from PetDB. (f) Mantle Bouguer Anomaly (MBA) from Thibaud et al. (1998). (g) Along-axis depth profile obtained from multibeam bathymetry data. 


\section{SEGMENTATION OF MID-OCEAN RIDGES}

(a)

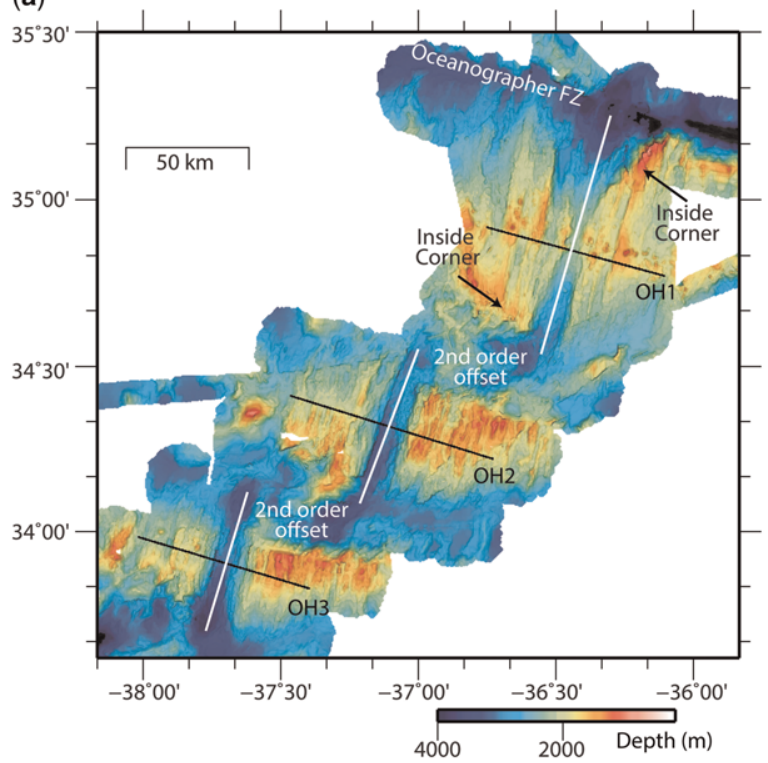

(c)

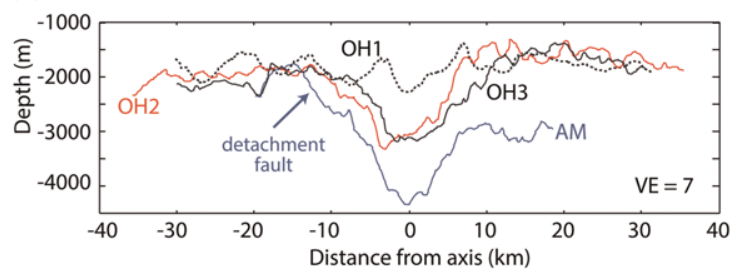

(b)

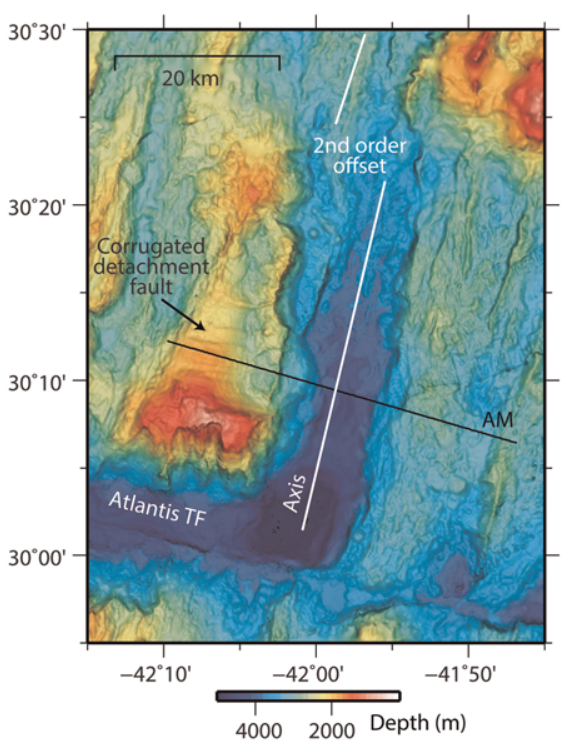

(d)

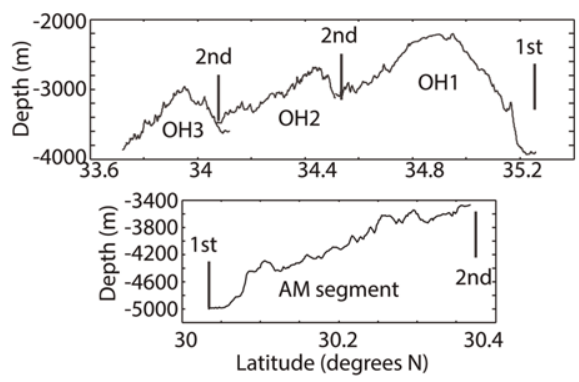

Fig. 9. Detailed bathymetry from the northern MAR illustrating contrasting ridge morphology (full spreading rate $22 \mathrm{~mm} \mathrm{a}^{-1}$ ). (a) Bathymetry for three segments south of the Oceanographer fracture zone. White lines run along the axis of the segments. Black lines show the location of the profiles in (c). Examples of the 'inside corner' at a transform fault and NTO are indicated. (b) Bathymetry for the segment north of the Atlantis TF. Continued extension on a long-lived detachment fault has produced the domed and corrugated Atlantis Massif (AM), which sits at the inside corner of the transform-ridge axis intersection. White lines mark the axis, and the black line the location of the profile in (c). (c) Depth profiles across the four segments shown in (a) and (b). Note the shallow depths in OH1, which is considered magmatically robust, and the deeper bathymetry in the AM segment, which is considered magmatically starved. (d) Along-axis profiles for the segments south of the Oceanographer FZ showing deeper segment ends and shallower segment centre. Along-axis profile for the AM segment is not typical. It shallows toward the north with no midpoint high.

TFs (Fig. 8). Figure 9 shows detailed bathymetry for a few ridge segments within this section. Slowspreading ridges such as the northern MAR are marked by a $1.5-3 \mathrm{~km}$-deep, 30-45 km-wide axial rift valley (Tapponnier \& Francheteau 1978; Macdonald 1986). An inner valley floor $(5-12 \mathrm{~km}$ wide) is bordered by valley walls in which large (hundreds of metres) inward-facing normal faults displace the crust upwards to form the crestal mountains. The inner valley floor, where new ocean crust is accreted, commonly contains an axial volcanic ridge (AVR) that is considered to be the predominant site of volcanic activity (Ballard \& van Andel 1977; Smith \& Cann 1993). AVRs can range up to several hundreds of metres high, several kilometres wide and tens of kilometres long.

\section{Geophysical properties of discontinuities and ridge segments}

Transform fault (TF) and first-order segments. TFs defining the first-order segmentation of the 


\section{S. M. CARBOTTE ET AL.}

MAR offset the ridge axis over varying lengths, with the greatest being the Romanche TF near the equator, which offsets the ridge axis by $c .900 \mathrm{~km}$ (Bonatti et al. 1994; Table 1). As the ridge axis approaches a TF, it deepens by $500-2000 \mathrm{~m}$ and MBA values increase, indicating thinner and/or cooler crust and mantle (Fig. 8; Sempéré et al. 1993; Detrick et al. 1995; Thibaud et al. 1998). Approaching some TFs, the AVR breaks down into groups or chains of isolated seamounts suggesting more limited magma supply near the ridgetransform intersection. In other places, however, a robust AVR reaches the transform discontinuity and fills the nodal basin at the intersection (e.g. Smith \& Cann 1999).

The inside of the $c .90^{\circ}$ bend of the plate boundary at both ridge-transform intersections and NTOs is referred to as the inside corner (Fig. 9). There are several differences in the characteristics of inside corners at first-order ridge-transform intersections compared to the opposite outside corners. Commonly, the inside corner flanks have shallower seafloor, higher gravity values, exposures of lower crustal and upper mantle rocks, and no volcanic features (e.g. Severinghaus \& Macdonald 1988; Cannat 1993; Tucholke \& Lin 1994; Escartín \& Lin 1995). These observations are consistent with tectonic thinning of the crust at the inside corner by long-lived (million years or more) detachment faults that can reach horizontal offsets of tens of kilometres and may account locally for $60-100 \%$ of plate separation (e.g. Tucholke et al. 1998; Ohara et al. 2001; Searle et al. 2003; Okino et al. 2004; Buck 2005; Cannat et al. 2006; Smith et al. 2006; Baines et al. 2008; Blackman et al. 2008; Grimes et al. 2008; Smith et al. 2008). In the detachment fault model, lower crust and upper mantle rocks are exhumed to the seafloor at the inside corner and the volcanic section is spread to the outside corner (Dick et al. 1981; Karson 1990; Tucholke \& Lin 1994). The formation of detachment faults is likely dependent on a balance between several factors, but magma input is considered a key variable. Numerical modelling suggests that long-lived detachment faults may form primarily when the fraction of plate separation taken up by magma accretion is between $c .0 .3$ and 0.5 (Buck et al. 2005; Tucholke et al. 2008; Olive et al. 2010), and this is supported by their common occurrence near ridge-transform intersections, where melt supply is thought to be reduced (Tucholke et al. 2008).

The along-axis topographic profile (Fig. 8g) shows that between TFs there is no regional arch as depicted in the schematic of hierarchical ridge segmentation of (Fig. 1; Macdonald et al. 1988). Larger regional-scale gradients are observed, however, including the gradual shoaling of the MAR as it approaches the Azores and Iceland hotspots. In addition, tectonic corridors have been identified along the southern MAR with similar geophysical and geochemical characteristics that appear to span broader sections of the ridge axis (hundreds of $\mathrm{km}$ ) and several TFs (Kane \& Hayes 1992). There are some transforms, however, that show strong variations across them, such as the Romanche TF, which marks a regional boundary in the geochemistry (Kashintsev et al. 2008) and possibly in the thermal structure of the underlying mantle (Bonatti et al. 2001).

Second-order discontinuities and segments. Between TFs along slow-spreading ridges, NTOs divide the axis into second-order segments with lengths of 20-100 km (Fig. 9a, b; Table 1; Sempéré et al. 1993; Gente et al. 1995; Thibaud et al. 1998). NTOs have typical offsets of 15$30 \mathrm{~km}$ (e.g. Sempéré et al. 1993) and many leave off-axis traces that indicate that some of these offsets migrate up and down the ridge axis resulting in segments with variable lengths (e.g. Gente et al. 1995). NTOs at slow-spreading ridges also have diverse morphologies. One type is characterized by a steep-sided ridge (sometimes referred to as a septal ridge) that appears to be fault-bounded (Sempéré et al. 1993) and separates the two segments (Sempéré et al. 1993; Spencer et al. 1997). A second type of NTO is an oblique shear zone, first identified by Sempéré et al. (1993) at $24^{\circ} 51^{\prime} \mathrm{N}$ on the MAR and described as a failed TF. The offset is accomplished by short, en echelon zones in which faulting is highly oblique to the normal spreading direction (e.g. Gràcia et al. 2000). A third type of NTO is marked by a step or offset in the volcanic axis between adjacent segments.

Along the axis of second-order segments, the shallowest depths are typically located near the segment centre, 400-700 m higher than segment ends (Fig. 9d) (e.g. Sempéré et al. 1993; Gente et al. 1995; Thibaud et al. 1998). Thibaud et al. (1998) categorized each second-order segment between $15^{\circ} \mathrm{N}$ and $35^{\circ} \mathrm{N}$ as 'hot' or 'cold'. Their hot segments, such as the three segments south of Oceanographer TF (e.g. Figs 8 \& 9a), show a strong change in along-axis MBA (25-35 mGal), bathymetry $(1-2 \mathrm{~km})$ and have a narrow axial rift (c. $5-10 \mathrm{~km})$. In contrast, cold segments, such as the one north of Atlantis transform (e.g. Figs 8 \& $9 b)$, have a smaller change in along-axis MBA (3-17 mGal), relief (hundreds of metres) and a wide axial rift (c. $15-20 \mathrm{~km})$. The shallow axial depths near segment centres, as argued by Neumann \& Forsyth (1993), likely represent a combination of hot and thick crust and thinner lithosphere than at deeper segments, and these shallow segments are commonly described as magmatically robust. 


\section{SEGMENTATION OF MID-OCEAN RIDGES}

Faulting style varies along the length of secondorder segments, with faults having larger throws (exceeding $1000 \mathrm{~m}$ in places) and wider spacing $(>5 \mathrm{~km})$ at segment ends than centres (200$400 \mathrm{~m}$ in relief, $<5 \mathrm{~km}$ spacing) (e.g. Mutter \& Karson 1992; Shaw 1992; Shaw \& Lin 1993). The change in fault style has been attributed to variations in lithospheric strength along the axis. Thus, largethrow faults develop at the ends of segments where low magma budget and thick axial lithosphere are inferred. And, as at TFs, long-lived detachment faults commonly form at the inside corners of NTOs exhuming lower crustal and upper mantle rocks to the seafloor (Tucholke et al. 1998). Studies have shown, however, that long-lived detachment faults can also form in the middle of second-order segments (e.g. Smith et al. 2006), and it has been suggested that adjacent detachment faults may link along the axis over a significant portion of a segment (e.g. Reston \& Ranero 2011). In some segments, detachment faults can dominate crustal accretion for many millions of years, producing large areas of seafloor covered by extinct detachment faults and exhumed deep-seated rocks (Dick et al. 2003; Schroeder et al. 2007; MacLeod et al. 2008; Smith et al. 2008). Escartín et al. (2008) estimated that active detachment faults occur along nearly $50 \%$ of the MAR axis between $12.5^{\circ} \mathrm{N}$ and $35^{\circ} \mathrm{N}$, which would mean that as much as $25 \%$ of new seafloor in this region may be formed by detachment faulting, consistent with earlier estimates (Cannat et al. 1995).

Along with increasing water depths, the axial MBA increases by $5-35 \mathrm{mGal}$ as a NTO is approached (Fig. 8; Sempéré et al. 1993; Detrick et al. 1995; Thibaud et al. 1998) supporting the idea of thin crust and thick axial lithosphere at segment ends. An early seismic refraction study at $33^{\circ} \mathrm{S}$ on the MAR (Tolstoy et al. 1993) examined the relationship between the seismically defined crustal thickness and variations in the MBA within a second-order segment, and found that the crust thinned by $2-3 \mathrm{~km}$ toward the NTO at the south end of the segment, consistent with the inferences from gravity data. A seismic experiment at $29^{\circ} \mathrm{N}$ by Wolfe et al. (1995) also found thicker crust at the segment centre than at the segment end.

Based on results from a seismic refraction experiment at three adjacent segments south of the Oceanographer $\mathrm{TF}$ at $35^{\circ} \mathrm{N}(\mathrm{OH}-1, \mathrm{OH}-2$ and OH-3; Fig. 9a), Hooft et al. (2000) concluded that there were significant variations in crustal thickness (c. $2-3 \mathrm{~km}$ ) along each segment, with the thickest crust at the centre of each segment and the thinnest crust at the segment ends, consistent with focused magma supply to the segment centre. Interestingly, they found that the average crustal thickness of the three segments was similar $(c .5 \mathrm{~km})$, suggesting similar total amount of melt supply despite significant differences in axial morphology (e.g. depths along axis, width of the valley floor, etc.) and gravity anomalies. A microseismicity study of $\mathrm{OH}-1$ found that the maximum depth of seismicity $(3-4 \mathrm{~km})$ beneath the centre of the segment is anomalously shallow compared to other MAR segments (Barclay et al. 2001). The authors speculated that the shallow microearthquakes are related to the thick crust and high crustal temperatures inferred for the centre of the OH-1 segment. Dunn et al. (2005) identify a low-velocity anomaly beneath the centre of segment $\mathrm{OH}-1$, which implies high temperatures and perhaps a small amount of melt, and might explain the thicker crust at the segment centre $(c .8 .5 \mathrm{~km})$ compared to the segment ends $(<4-5 \mathrm{~km})$.

As a whole this body of work suggests that more melt is supplied to the centre of a slow-spreading second-order segment and that melt supply is limited at the ends of the segments. Whether the melt is supplied vertically from the mantle along the entire axis, primarily to the centre of the axis and distributed along axis at a shallow level, or by a combination of the two remains an area of active research.

Most seismic studies at the MAR have not imaged crustal magma bodies beneath the ridge axis (e.g. Purdy \& Detrick 1986; Detrick et al. 1990; Canales et al. 2000) suggesting that the magma bodies are deep, small and/or ephemeral features (e.g. Sinton \& Detrick 1992). Calvert (1995) suggested the presence of a small magma body beneath the segment immediately south of the Kane $\mathrm{TF}$, but the seismic images available were of poor quality. A combined seismic and electromagnetic study along the Reykjanes Ridge $\left(57^{\circ} 45^{\prime} \mathrm{N}\right)$ did identify an AML located about $2.5 \mathrm{~km}$ beneath a large AVR (Sinha et al. 1998). In addition, a large swarm of hydroacoustically and teleseismically recorded earthquakes in 2001 in the Lucky Strike segment near $37^{\circ} 20^{\prime} \mathrm{N}$ was interpreted by Dziak et al. (2002) as a magma/dyke emplacement event into the crust beneath the Lucky Strike volcano, a c. $1 \mathrm{~km}$ high edifice in the segment centre; however, there was no along-axis migration of seismicity to indicate lateral propagation of a dyke and subsequent surveys showed no indication of eruption on the seafloor. Subsequently, a seismic reflection study of the Lucky Strike segment revealed a well-defined intra-crustal reflector interpreted as the roof of an AML c. $3 \mathrm{~km}$ below the large Lucky Strike volcano (Singh et al. 2006a, b).

The spatial and temporal patterns of earthquakes recorded by autonomous hydrophones on the northern MAR (Smith et al. 2003; Simão et al. 2010) show no simple relationship to second-order segment variables (e.g. length or trend of the segment, 


\section{S. M. CARBOTTE ET AL.}

maximum offset of discontinuities or along-axis change in MBA and water depths). Local microearthquake experiments have also shown differing trends along axis. For example, Kong et al. (1992) observed a progressive shoaling of microearthquakes toward the segment centre at $26^{\circ} \mathrm{N}$, which they interpreted as evidence of a recent injection of magma in the region of shallower earthquakes. In contrast, at $29^{\circ} \mathrm{N}$, Wolfe et al. (1995) did not observe a shallowing of microearthquakes toward the segment centre and suggested that there had not been a recent magma injection there. In general, focal depths of earthquakes in these and other studies (Toomey et al. 1988; de Martin et al. 2007) range between 3 and $8 \mathrm{~km}$, defining the thickness of the lithosphere at the MAR. It is important to note, however, that the thickness of the seismogenic layer defined by focal depths may reflect short-lived phenomena (e.g. magma movements, fault-slip events) that may not be indicative of the longer-term thickness of the brittle lithosphere.

\section{Geochemical properties of discontinuities and ridge segments}

Early reconnaissance sampling of the MAR revealed prominent gradients in isotopic and trace element composition as a function of distance from chemically enriched, near-ridge mantle hotspots, such as Iceland or the Azores (e.g. White \& Schilling 1978; Fig. 8b). These regular chemical gradients in source composition often show abrupt changes at TFs such as the Gibbs or Jan Mayen TFs south and north of Iceland (Schilling et al. 1983; Dosso et al. 1999; Blichert-Toft et al. 2005).

The identification of smaller scales of geochemical segmentation along slow-spreading ridges has been problematic for a number of reasons. First, compared to fast-spreading ridges, slow-spreading ridges often show more significant chemical variability over short spatial scales (e.g. Langmuir et al. 1992; Batiza 1996; Rubin \& Sinton 2007). This local chemical variability was demonstrated, for example, in early studies of the FAMOUS area at c. $36^{\circ} 50^{\prime} \mathrm{N}$ (Fig. 8; e.g. Langmuir et al. 1977) and has been attributed to the prevalence of discrete pockets of enriched mantle (e.g. Michael et al. 1994) and to less efficient pooling of chemically distinct melts prior to eruption (e.g. Coogan et al. 2000; Rubin \& Sinton 2007). Additional challenges in exploring magmatic segmentation at slow spreading rates is that few significant lengths of slowspreading ridge axes have been sampled at sufficient density and with good age control to fully characterize both inter-segment variabilities.

Despite these complications, sampling in a few areas of the MAR is sufficient to explore relationships between geochemical and tectonic segmentation and, in particular, the question of central v. multiple magma supply to tectonic segments. In a study of the MAR south of the Kane TF at $24^{\circ} \mathrm{N}$, Reynolds \& Langmuir (1997) argued for multiple magma supplies based on the observation that melts at the segment ends differed in parental magma composition from those at the segment centre, a finding similar to that reported by Batiza et al. (1988) along the southern MAR (see also Niu \& Batiza 1994).

Gale et al. (2011) studied both intra- and intersegment variability along the adjacent second-order Menez Gwen and Lucky Strike segments along the MAR. Exploiting the fact that there is a gradient in isotopic composition as a function of distance from the influence of the Azores plume, their results (Fig. 10) document a step function in average isotopic composition across the Pico TF. This observation, combined with the presence of robust central volcanoes, underlain at Lucky Strike by a crustal magma lens (Singh et al. 2006a, b) and thicker crust at segment centres, provide general support for the idea that melt supply is focused toward the centre of each segment. Gale et al. (2011) further noted, however, that gradients in some trace element ratios within each segment argue in favour of multiple sites of vertical magma supply. Ultimately, these authors concluded that a hybrid model involving both central and lesser amounts of distributed melt supply from depth, followed by shallow along-axis dyking, is likely required to explain the complex geochemical signals.

Because magmas erupted along the MAR often display great chemical diversity resulting from source heterogeneity, even far from hotspots and over spatial scales of a few kilometres or less, it has been difficult to isolate chemical signatures reflecting variations in melting parameters (e.g. Shirey et al. 1987; Gale et al. 2011, 2013). This makes it problematic to apply the models of primary and secondary magmatic segments developed for fast-spreading ridges (Sinton et al. 1991) to the slow-spreading environment.

\section{Ultraslow-spreading ridges}

Ultraslow ridges (total spreading rate $<20 \mathrm{~mm} \mathrm{a}^{-1}$ ) include the Southwest Indian Ridge (SWIR), the Mohns, Knipovitch and Gakkel Ridges in the North Atlantic and the Mid-Cayman Rise in the Caribbean. These ridges had been largely unexplored until the 1990s, but significant portions are now mapped, both on and off axis (e.g. Mendel et al. 1997; Rommevaux-Jestin et al. 1997; Grindlay et al. 1998; Sauter et al. 2001; Okino et al. 2002; Cannat et al. 2003, 2006; Cochran et al. 2003; Dick et al. 


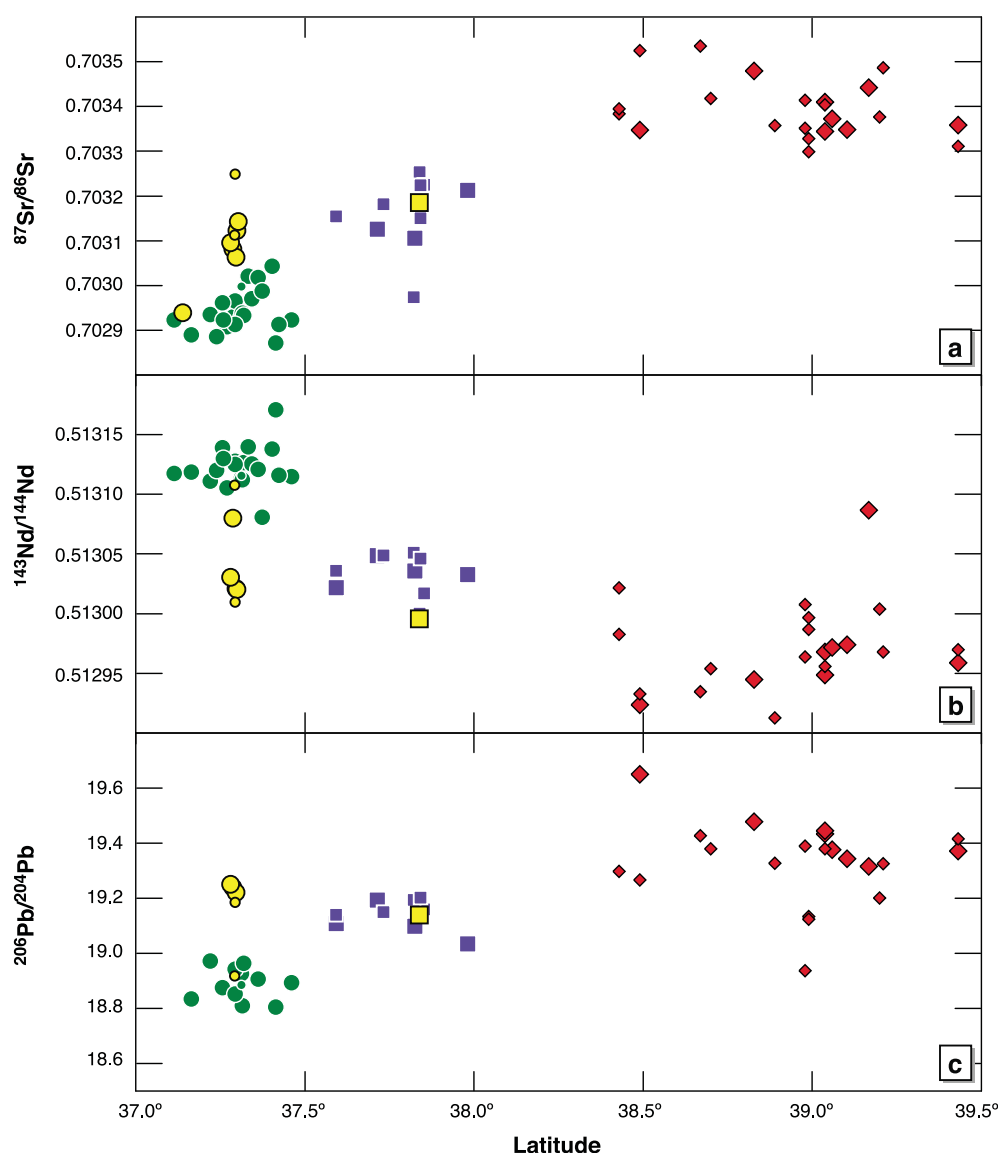

Fig. 10. (a-c) The ${ }^{87} \mathrm{Sr} /{ }^{86} \mathrm{Sr},{ }^{143} \mathrm{Nd} /{ }^{144} \mathrm{Nd}$ and ${ }^{206} \mathrm{~Pb} /{ }^{204} \mathrm{~Pb}$ v. latitude for Lucky Strike (circles), Menez Gwen (squares) and KP2-3 segments (diamonds). A sharp jump in isotopic signature occurs between the northernmost end of Lucky Strike and the southernmost end of Menez Gwen and no clear within-segment gradients, in contrast to a more gradual increase seen within segments in the moderately incompatible element ratios (not shown). 'Central spikes' in isotopic ratios are also seen within the Lucky Strike segment. From Gale et al. (2011).

2003; Michael et al. 2003). Because the MidCayman, Mohns and Knipovich ridges are relatively short $(<400 \mathrm{~km})$, the range of ultraslow segmentation scales is best investigated on the SWIR and Gakkel ridges. Figures 11 and 12 illustrate characteristics for the eastern part of the SWIR. Until recently, little was known about ultraslow ridges so we begin our discussion with an overview of their geophysical and geological characteristics.

Long ultraslow ridges, such as the Gakkel Ridge (GR) and the SWIR, show a broad range of axial depths and MBA values. As is the case at faster spreading ridges, averages of axial MBA values for long $(>200 \mathrm{~km})$ stretches of these ridges are well correlated with average axial depth (Georgen et al. 2001; Cochran et al. 2003; Michael et al. 2003). MBA values typically increase as the ridge axis deepens, indicating higher sub-seafloor densities either due to changes in average regional crustal thickness or in the average density of the subaxial mantle, or both. In contrast to what is observed at faster spreading ridges (e.g. at the GSC (Fig. 7) or at the MAR south of the Azores (Fig. 9)), regional axial depth and MBA variations on the SWIR and GR do not as a rule describe large-scale gradients with a deepening of the axis away from hotspots. Instead, average axial depth and MBA at the GR and SWIR vary stepwise over short distances, coincident in some cases with large offset TFs. The Gallieni TF along the SWIR, for example, coincides with a $1000 \mathrm{~m}$ deepening of average regional axial depth, and with a $c .40 \mathrm{mGal}$ contrast in average regional MBA (Fig. 11). In other cases, however, no surficial tectonic expression is observed other than a NTO (e.g. at $3^{\circ} \mathrm{E}$ on the GR; Michael et al. 2003). 
(a)

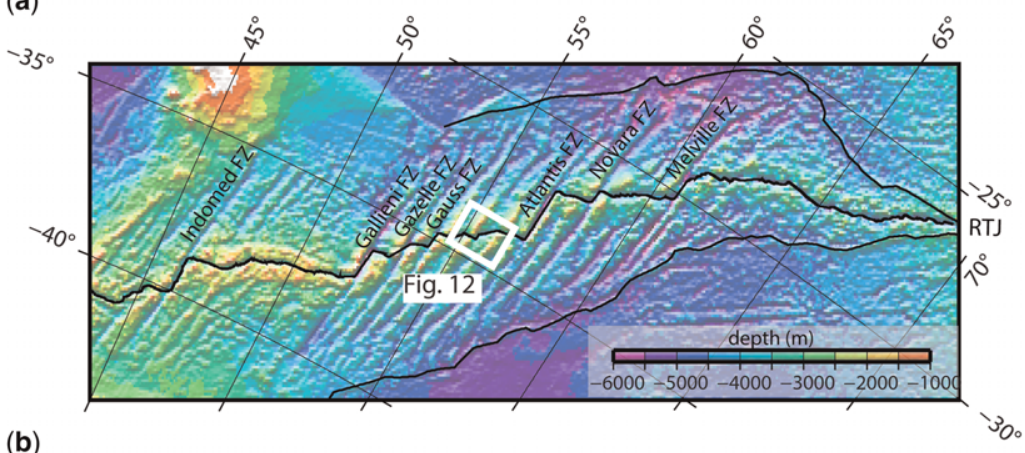

(b)

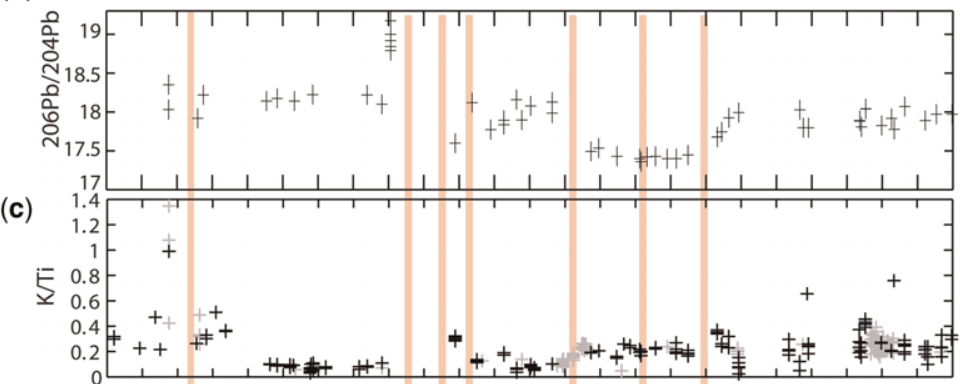

(d)

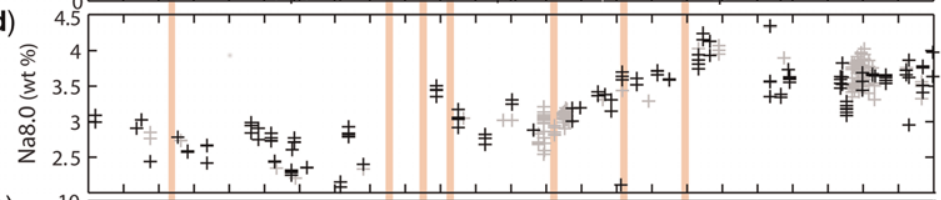

(e)

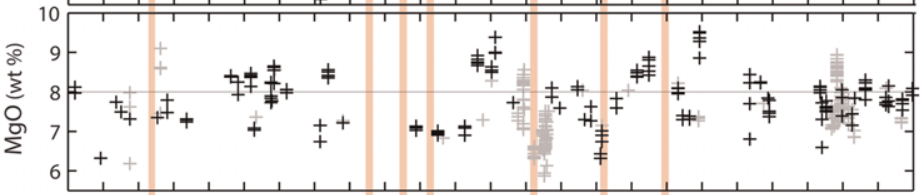

(f)

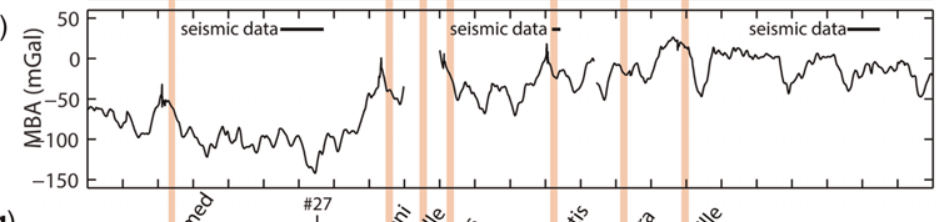

(g)

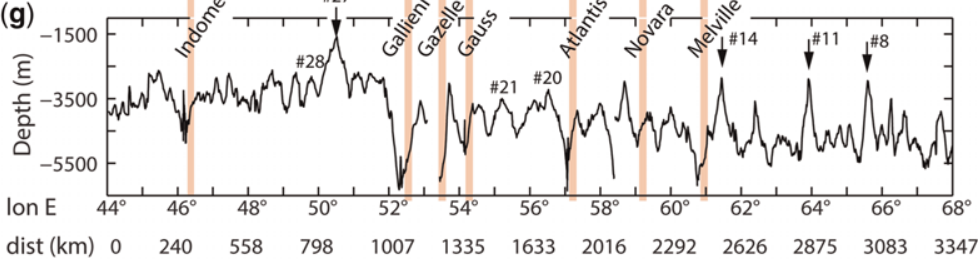

Fig. 11. Variations in ridge properties along the eastern South West Indian Ridge (SWIR). (a) Seafloor bathymetry for the SWIR (44-68 E) from the global satellite-derived seafloor topography (Sandwell and Smith, http://topex.ucsd. edu/marine_topo/). Black line marks the ridge axis and its offsets. Location of detailed bathymetry map in Figure 12 is shown by a white rectangle. Transform faults are labelled. In the panels below, shaded vertical bars show the locations of transform faults. (b) Basalt geochemistry from Meyzen et al. (2005). (b-e) Geochemical data, renormalized and culled as described in the caption to Figure 2; data from PetDB (pale crosses) and from Cannat et al. (2008; black crosses). (f) Mantle Bouguer Anomaly (MBA) modified from Sauter \& Cannat (2010). Bars outline areas for which seismic data are available. (g) Along-axis depth profile obtained from multibeam bathymetry data (Sauter \& Cannat 2010). Segments referred to in the text are numbered. 


\section{SEGMENTATION OF MID-OCEAN RIDGES}

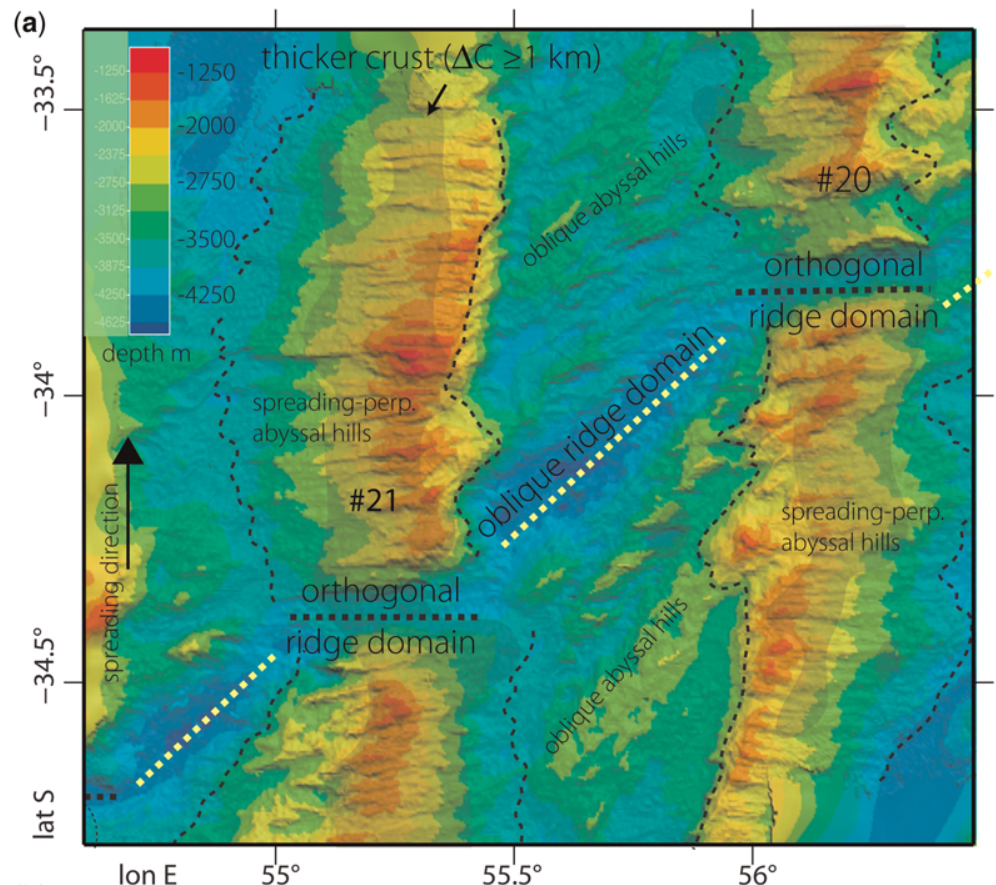

(b)
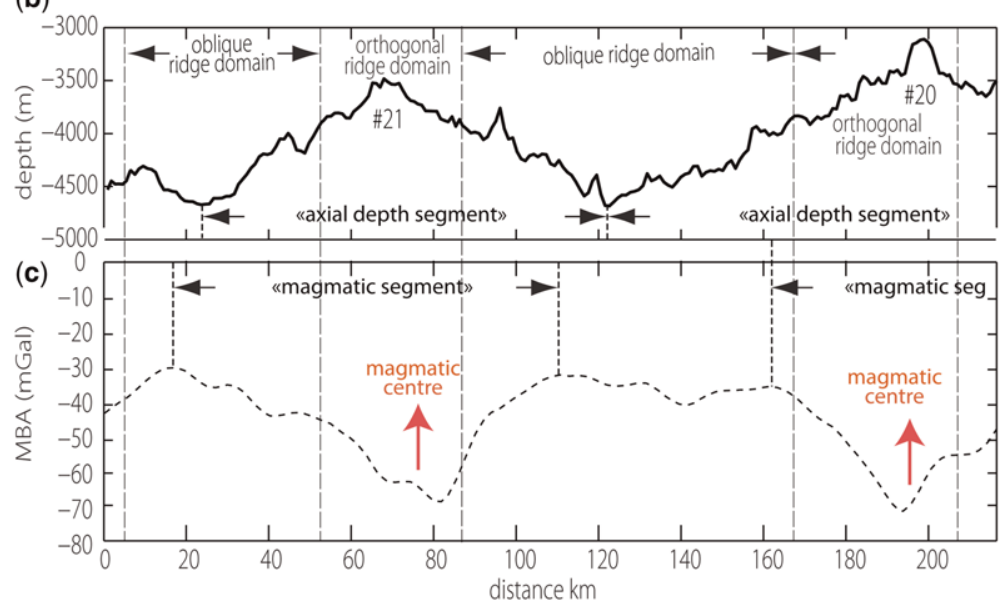

Fig. 12. Detailed bathymetry from the SWIR illustrating orthogonal and oblique ridge domains. (a) Bathymetry for segments \#20 and \#21 between the Gauss and Atlantis FZs (see location in Fig. 11). Dashed lines run along axis, in white for oblique domains and in black for orthogonal domains. Grey shaded areas extending off-axis along flow lines from orthogonal domains have thicker than average gravity-derived crust (Mendel et al. 2003). (b) Along-axis depth profile (detail of Fig. 11g). Note that orthogonal segments are shallower and that the succession of bathymetric lows limits "axial depth segments" that include orthogonal and oblique domains. (c) Along-axis MBA profile (detail of Fig. 11f). Note that a large portion of the oblique domain centreed at $55.75^{\circ} \mathrm{E}$ has a flat along-axis MBA profile and that the succession of MBA highs therefore limits "magmatic segments" that mostly correspond to the orthogonal domains.

Active seismic tomographic experiments have been carried out at four locations along the SWIR: near $66^{\circ} \mathrm{E}$ and $57^{\circ} \mathrm{E}$ (Minshull \& White 1996; Muller et al. 1999; Minshull et al. 2006); near $51^{\circ} \mathrm{E}$ (ridge segments 27 and 28; Fig. 11; Zhao et al. 2013;
Jian et al. 2014); and at $37^{\circ} \mathrm{E}$ near Marion Island (Seama et al. unpublished report, http://www.inter ridge.org/de/node/5452). The seismic structure of the GR has been investigated at 18 locations between $5^{\circ} \mathrm{W}$ and $60^{\circ} \mathrm{E}$, using arrays of geophones 


\section{S. M. CARBOTTE ET AL.}

on drifting pack ice as a recording system (Jokat et al. 2003; Jokat \& Schmidt-Aursch 2007). None of these active seismic surveys have identified negative velocity anomalies that could be interpreted as melt in the crust. The crust is thicker beneath volcanic centres (up to $7 \mathrm{~km}$ at SWIR segment 8; Muller et al. 1999; Minshull et al. 2006). The thickest crust (10.4 km; Jian et al. 2014) has been found beneath the centre of SWIR segment 27 (one of the shallowest ultraslow segments, with a strongly negative MBA; Fig. 11), and the thinnest crust $(1.5 \mathrm{~km})$ has been found for the deepest portions $(>4500 \mathrm{~m})$ of the GR (Jokat et al. 2003; Jokat \& Schmidt-Aursch 2007) and of the SWIR east of the Melville Fracture Zone (Muller et al. 1999; Fig. 11), which also have more positive MBAs. Widespread ultramafic outcrops in these thin-crust regions indicate that the seismically defined crust in these areas is mostly serpentinized and fractured mantle rocks. Seismically determined crustal thickness, regional axial depth and MBA are thus generally well correlated at ultraslow ridges, as is also found at the slowspreading MAR.

Ridges spreading at ultraslow rates also share many of the morphologic characteristics of slowspreading ridges. The ridge axis has an axial valley, as do most ridges with spreading rates $<40 \mathrm{~mm} \mathrm{a}^{-1}$ (Small 1998). Most regions of the axis display a succession of along-axis highs and lows with typical half-wavelengths of $30-100 \mathrm{~km}$ (Fig. 11; Rommevaux-Jestin et al. 1997; Grindlay et al. 1998) similar to the second-order segmentation found at slow-spreading ridges (Fig. 8; Sempéré et al. 1990). Again, similar to slow ridges, outcrops of serpentinized peridotites are common (Dick 1989; Dick et al. 2003; Michael et al. 2003; Seyler et al. 2003; Hayman et al. 2011; Sauter et al. 2013). These ultramafic complexes are exhumed by detachment faults that locally bear spreading-parallel $100 \mathrm{~m}$-scaled corrugations (Searle et al. 2003; Cannat et al. 2009; Hayman et al. 2011; Zhao et al. 2013) and are similar to corrugated detachment faults at slow ridges (Fig. 9b).

There are, however, characteristics of ultraslow ridge axis morphology that are not found at faster spreading ridges. Most notably, some regions of ultraslow ridges, extending several $100 \mathrm{~km}$ along axis ('supersegments' in the terminology proposed by Dick et al. 2003) comprise domains of very sparse volcanism that extend up to $80 \mathrm{~km}$ along axis. Ultramafic outcrops are ubiquitous in these domains (Dick et al. 2003; Michael et al. 2003; Sauter et al. 2013) and associated with specific mesoscale structures; smooth, flat and uncorrugated seafloor, with sparse hummocky volcanism (Cannat et al. 2006; Sauter et al. 2013). Regions of the axis that comprise such 'amagmatic' (Dick et al. 2003; Michael et al. 2003) or 'non volcanic' (Cannat et al. 2006) ultramafic domains are separated by local regions of strongly localized volcanism, building isolated, widely spaced, and very large axial volcanoes standing $>2000 \mathrm{~m}$ above the surrounding seafloor (Mendel et al. 1997; Cannat et al. 1999; Okino et al. 2002; Michael et al. 2003). Volcanism focused to such a marked extent has not been described at faster spreading ridges. Here we interpret these amagmatic domains with highly focused volcanism as a type of second-order segmentation at ultraslow ridges that will be described in detail below.

\section{Geophysical properties of discontinuities and ridge segments}

Transform faults and first-order segments. The spacing of large offset TFs along ultraslowspreading ridges is typically a few hundred kilometres (Fig. 11), similar to faster spreading ridges. The characteristics of ridge-transform intersections are similar to those of slow-spreading ridges, and there is no regional doming of axial topography or MBA between large-offset transforms. As mentioned before, however, some large transforms coincide with steps in these characteristics. Other large TFs, however, do not mark changes in ridge morphology or geophysical signature (e.g. Indomed TF; Fig. 11).

Second-order discontinuities and segments. There are two primary modes of non-transform bounded segmentation recognized along ultraslow ridges; wide amagmatic domains with highly focused volcanism and orthogonal volcanic domains with oblique basins (Table 1). The large-offset Melville TF (Fig. 11) marks the transition between regions of the SWIR characterized by these different modes. To the west, the succession of axial topographic highs/MBA lows and topographic lows/ MBA highs is comparable to the second-order segmentation observed at slow-spreading ridges (Fig. 9). To the east, and extending to the Rodrigues Triple Junction, wide amagmatic domains with highly focused volcanism are found.

Wide amagmatic domains and focused volcanism. In the $c .800 \mathrm{~km}$-long region east of the Melville TF there are three prominent axial volcanoes (numbered 8,11 and 14 in Fig. 11), each c. $2500 \mathrm{~m}$ high and extending $c .60 \mathrm{~km}$ along axis, forming spreading-perpendicular volcanic ridges (Mendel et al. 1997). The mean along-axis slopes on these volcanoes (up to $90 \mathrm{~m} \mathrm{~km}^{-1}$; Cannat et al. 1999) are about double those measured west of the Melville TF and along axis in second-order segments of the MAR (Blackman \& Forsyth 1991). This contrast in slope suggests distinct mechanisms for creating this topography, and it has 


\section{SEGMENTATION OF MID-OCEAN RIDGES}

been proposed that the oceanic crust formed at these volcanoes includes a greater proportion of effusive lava than typical slow-spread crust. The volcanoes rest on seafloor that is very deep $(>4500 \mathrm{~m})$ and nearly amagmatic, based on the lack of typical volcanic features such as ridges and cones (Cannat et al. 2006) and on dredging of mostly ultramafic rocks (Sauter et al. 2013).

The association here of non-volcanic domains with large and widely-spaced axial volcanoes is found in other regions of ultraslow-spreading ridges as well. By their length (several hundred kilometres along axis) these ridge regions would be classified as first-order segments elsewhere, yet they are not as a rule limited by first-order axial discontinuities (i.e. large offset TFs). At the GR nonvolcanic domains and focused volcanoes are found between $3^{\circ} \mathrm{E}$ and $85^{\circ} \mathrm{E}$ and the limit at $3^{\circ} \mathrm{E}$ corresponds with a $10 \mathrm{~km}$ NTO (Michael et al. 2003). Most volcanic centres within these long nonvolcanic domains are found between $30^{\circ} \mathrm{E}$ and $85^{\circ} \mathrm{E}$, in the region of the GR that has the slowest spreading rate. In the western part of the SWIR the association of amagmatic domains and large isolated volcanoes is found in the $10-16^{\circ} \mathrm{E}$ oblique supersegment that is limited to the west by the Shaka TF and to the east by a change in ridge obliquity with no significant ridge offset (Dick et al. 2003).

The tall volcanoes are seismically active: swarms of teleseismic events $(M \geq 4.5)$ were recorded in 2008 at the SWIR volcanic centre 8 in Figure 11 (Global Seismology Network catalogue) and in 1999 at an axial volcano located at $85^{\circ} \mathrm{E}$ on the GR (Müller \& Jokat 2000; Tolstoy et al. 2001). A brief microseismicity study at SWIR volcano 11 (Fig. 11; Yamada et al. 2002) suggested hypocentres depths up to $8 \mathrm{~km}$ below the seafloor, while a more comprehensive microseismicity study on the Knipovich ridge found maximum hypocentral depths c. $20 \mathrm{~km}$ beneath the axial basins, and c. $8 \mathrm{~km}$ beneath the volcanic centres (Jokat et al. 2012; Schlindwein et al. 2013). The results for axial basins suggest a brittle lithospheric thickness in excess of the $8-10 \mathrm{~km}$ that is typically inferred from hypocentre depths at the MAR (Toomey et al. 1988; Wolfe et al. 1995; de Martin et al. 2007). Such a thick axial lithosphere, if confirmed for other ultraslow regions, would mean very cold thermal conditions in the nearly amagmatic domains, and strong thermal contrasts between the volcanic centres and the deeper axial basins.

Dick et al. (2003) proposed that the association of non-volcanic domains with large and widely spaced axial volcanoes is typical of extremely low rates $\left(<12 \mathrm{~mm} \mathrm{a}^{-1}\right)$ of effective spreading, either because of ultraslow plate divergence (eastern GR) or because the ridge is highly oblique to the spreading direction (western SWIR and Knipovich). However, spreading rate does not explain the abrupt change of axial morphologies that occurs with no change in spreading rate across the Melville TF at the SWIR (Fig. 11). There, and also along the GR (Cochran 2008; Goldstein et al. 2008), this abrupt transition coincides with significant changes in mantle geochemistry, as discussed below.

Spreading in the amagmatic domains is accommodated by long, axis-parallel detachment faults (Sauter et al. 2013). In this tectonic mode of spreading, the axial topographic and MBA profiles are nearly flat (Fig. 11 between volcanoes 8, 11 and 14) and there is no evidence for localized offsets of the ridge axis. In this context, the pronounced along-axis topographic and MBA gradients associated with the volcanoes may define the boundaries of more magmatic second-order spreading segments. Alternatively, several authors have proposed that melt produced in the mantle beneath the adjacent nearly amagmatic domains could be focused for over tens of kilometres toward the volcanoes (Cannat et al. 1999, 2003; Okino et al. 2002; Sauter et al. 2004; Standish et al. 2008; Cochran 2008). In this case, the second-order segments in these ultraslow ridge regions would also include part of the amagmatic domains adjacent to axial volcanos.

Orthogonal volcanic domains and oblique basins. Ultraslow-spreading ridges also comprise regions with more distributed volcanism where domains of smooth amagmatic seafloor are absent or of limited extent, and the axial profile displays successions of topographic highs and lows with typical half-wavelengths of $30 \mathrm{~km}$ to $100 \mathrm{~km}$, comparable to the second-order segments of the MAR (Fig. 9). The ends of these segments on ultraslowspreading ridges typically display elongated basins that trend sub-parallel to the regional orientation of the ridge (Mendel et al. 1997; Grindlay et al. 1998; Okino et al. 2002; Michael et al. 2003). This contrasts with segment ends at the slow-spreading MAR, which typically exhibit semi-circular nodal basins adjacent to the discontinuities (Sempéré et al. 1990). In addition, on ultraslow-spreading ridges, the elongate basins at segment ends are often oblique to the spreading direction, while the shallower and more volcanically active segment mid-points are often orthogonal to spreading (Fig. 12). In other regions, however, for example locally at the SWIR (Mendel et al. 1997; Cannat et al. 1999), spreading-perpendicular AVRs are found within the confines of a deep and commonly oblique axial valley. In this configuration, the deeper points of the along-axis profile correspond to the axial valley floor between the volcanic ridges.

The deeper axial regions found between these volcanic zones have a significant width in the 
S. M. CARBOTTE ET AL.

(a)

\section{Fast Spreading Principal Magmatic Segment}

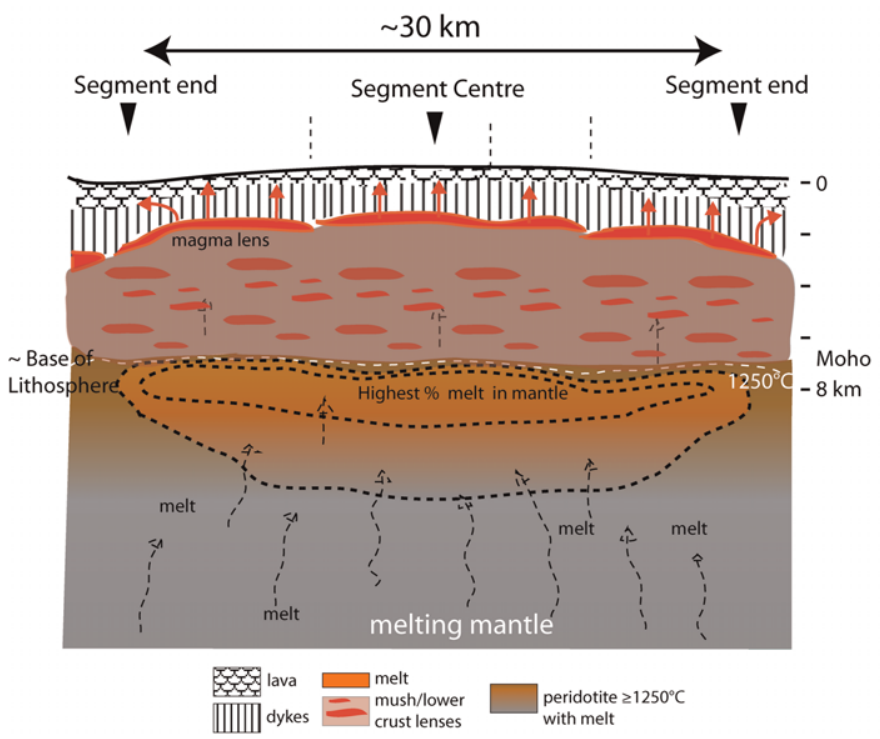

(b)

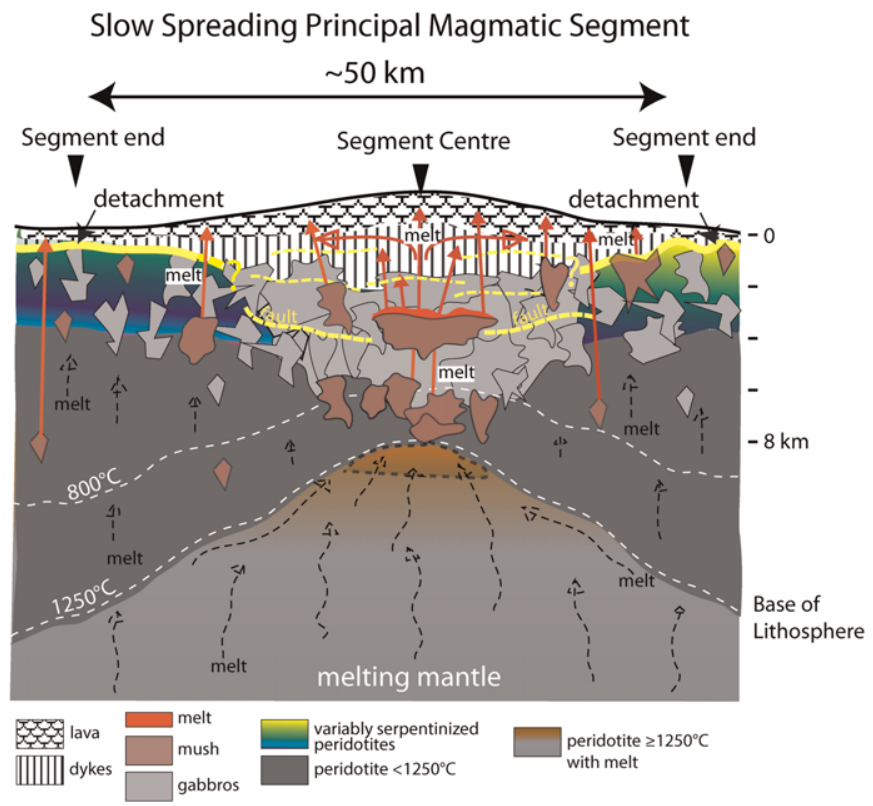

Fig. 13. Sketch showing along-axis section of idealized magmatic spreading segment at fast and slow ridges based on studies summarized in this article. (a) At fast-spreading ridges, rising mantle melts accumulate at the base of the crust (orange-grey) beneath each principal magmatic segment. The crustal magmatic system is composed of a more or less steady state magma lens or sill (red) that is partitioned into finer-scale segments coincident with the finest-scale seafloor segmentation. This shallow magma lens resides above a lower crustal zone of crystal mush and possible lower crustal sills (red lozenges embedded in red-grey). Red arrows in the dyke section indicate trajectories of magma transport during dyking (primarily vertical with minor lateral transport in places). (b) At slow-spreading ridges, strong focusing of mantle melts leads to thick crust/thin axial lithosphere at centre and thin crust/thick axial lithosphere at ends of each principal magmatic segment. Crustal magma bodies are more localized and ephemeral; both vertical and lateral magma transport during dyking may occur. Normal faulting is highly localized in detachments at segment ends and more distributed between several axial valley faults at segment centres. Figure modified from Cannat et al. (1995). See text for further discussion. 


\section{SEGMENTATION OF MID-OCEAN RIDGES}

(a)

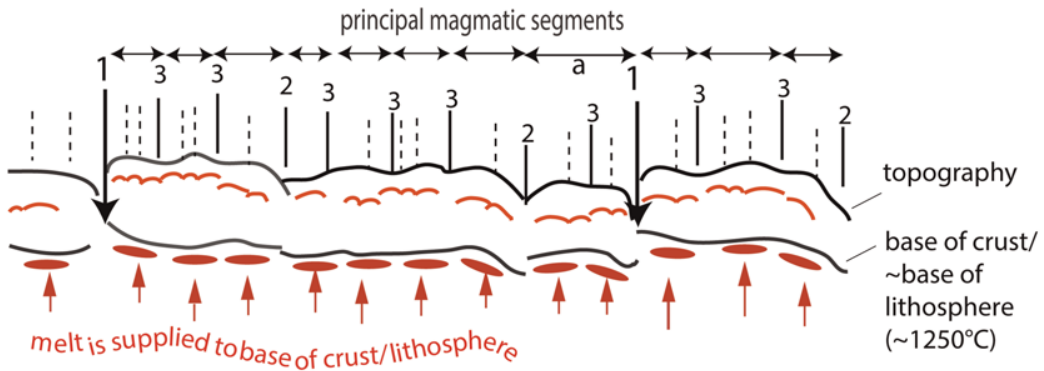

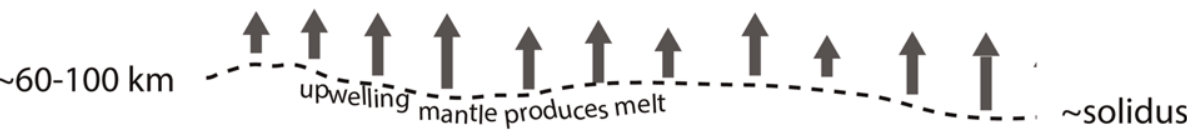

(b)

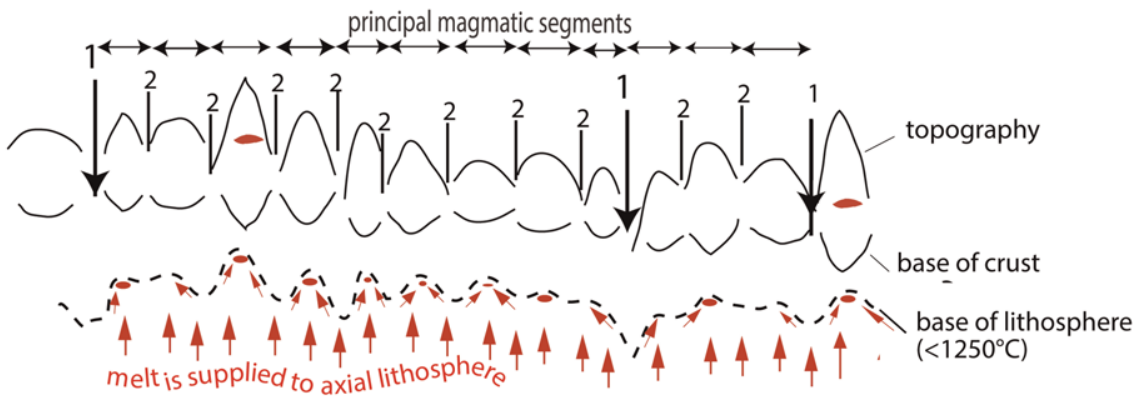

$10 \mathrm{~km}$

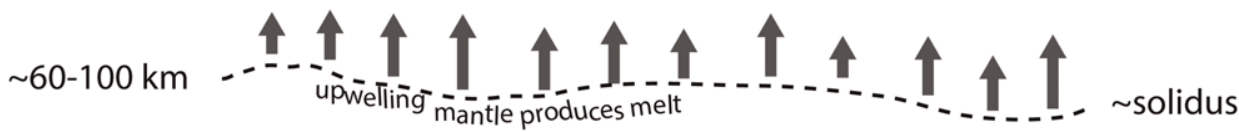

Fig. 14. Schematic illustration of ridge segmentation at fast- and slow-spreading ridges, and relationship to mantle melting and ascent. (a) At fast-spreading ridges, as well as at intermediate spreading ridges that are magma-rich, the ridge axis is segmented into principal magmatic segments that coincide primarily with third-order tectonic segments (bound on one or both ends by a third-order discontinuity, numbered vertical lines indicate discontinuity order). Each segment receives melt from an upper mantle melt source (thin vertical arrows) that pools at the base of the crust (filled ellipses). Within the crust, melts accumulate within a shallow magma lens (thin line) that is partitioned into smaller segments roughly coincident with the finest-scale tectonic segmentation (fourth-order discontinuities: vertical dash lines). Relatively uniform thickness crust is formed at most segments with modest thinning at some transform faults (vertical arrows labelled ' 1 '). Regional variations in mantle upwelling and melt production at depth (thick arrows) arise due to mantle temperature (shown as undulations in the solidus) and/or compositional variations. (b) At slow-spreading ridges, principal magmatic segments coincide with tectonic segments identified as second-order (numbered vertical lines indicate discontinuities of order 1-2). Strong melt focusing (indicated with small subhorizontal to subvertical arrows) at the base of the axial lithosphere (thin dashed line) results in large variations in crustal thickness within segments, with thicker crust typically emplaced approximately mid-segment and where short-lived crustal magma bodies (filled ellipses in crust) can form.

direction perpendicular to spreading. For example the oblique basin between the shallower and orthogonal ridge domain of segments \#20 and \#21 (Fig. 12) has a width of $c .50 \mathrm{~km}$ in the direction perpendicular to spreading and therefore accommodates plate divergence over a significant length of the plate 


\section{S. M. CARBOTTE ET AL.}

boundary. This has led to the idea that these wide and deep domains of ultraslow-ridges represent a new class of spreading segments (Dick et al. 2003). Other workers have interpreted these domains as wide axial discontinuities separating short volcanic segments (Mendel et al. 1997). While these interpretations may both be valid, one could argue (e.g. Cochran 2008) that a true magmatic spreading segment (as opposed to more specific definitions such as a tectonic or volcanic segment) should have its own melt supply system. Most workers to date have hypothesized that melt produced in the mantle beneath these deeper portions of the axis is then focused to the more volcanically robust orthogonal regions, based on geophysical (RommevauxJestin et al. 1997; Grindlay et al. 1998; Cannat et al. 1999, 2003; Okino et al. 2002; Jokat \& SchmidtAursch 2007) and geochemical (Standish et al. 2008) arguments as described below.

\section{Geochemical properties of discontinuities and ridge segments}

No ultraslow spreading ridge segments have been sampled at densities sufficient to explore intra- or inter-segment chemical variations, like those described for the slow-spreading northern MAR (Gale et al. 2011). The SWIR is currently the most densely sampled ultraslow spreading ridge (Fig. 11 ), but even here data are only sufficient to describe regional variations and their possible correspondence to first-order segmentation. Based on present sampling of the SWIR from $44^{\circ} \mathrm{W}$ to $68^{\circ} \mathrm{W}$, magmatic segmentation defined by changes in isotopic composition appears to coincide with some firstorder discontinuities, such as the Melville and Atlantis TFs (Fig. 11) (Meyzen et al. 2005). Some intervening first-order segments appear to erupt magmas of relatively uniform isotopic and trace element composition (e.g. segments spanning the Atlantis, Novara and Melville transforms), while other segments show large-amplitude isotopic variations over small scales, independent of ridge segmentation.

With respect to variations in extents of melting, average $\mathrm{Na}_{8.0}$ values increase from $44^{\circ} \mathrm{W}$ to $68^{\circ} \mathrm{W}$, consistent with the $c .3000 \mathrm{~m}$ decrease in average axial depth, suggesting decreasing extents of melting (Fig. 11) (Cannat et al. 2008). In the more densely sampled area between the Atlantis and Melville TFs, $\mathrm{Na}_{8.0}$ values grade smoothly through the two first-order segments, suggesting that despite the isotopic distinctions between these first-order offsets (Meyzen et al. 2005), variations in mantle melting occur independent of tectonic segmentation. Finally, apart from the eruption of more fractionated lavas in the vicinity of some transforms, variations in extents of fractionation $(\mathrm{MgO} w \mathrm{wt} \%)$ show little systematic inter- or intrasegment relationships. Further sampling of ultraslow spreading centres at scales and densities sufficient to explore both intra- and inter-segment variability is required to understand the extent to which ultraslow spreading centres represent an end-member in a continuum as a function of spreading rate, or display entirely unique geochemical characteristics.

\section{Synthesis and discussion}

Geophysical and geochemical studies conducted since the 1980s confirm early inferences that the tectonic segmentation of the MOR defined by transform and non-transform discontinuities of varying sizes is closely linked to segmentation in the magmatic system that feeds the ridge. Variations in a range of ridge properties are observed at all spreading rates that indicate tectonic offsets of the ridge axis coincide with disruptions in the underlying magma supply system. Furthermore, ridge segments at fast- and intermediate-spreading ridges, separated in places by discontinuities with very small offsets of $<2-3 \mathrm{~km}$, often display distinct properties indicating they are fed by different magmatic systems. The notion that the global MOR is composed of a series of magmatic spreading segments, each with its own magma plumbing system extending into the underlying asthenosphere is generally supported.

In Figure 13, we summarize the main features of what we refer to as a 'principal magmatic segment' defined as the length of ridge fed by a discrete melt accumulation in the shallow asthenosphere at fastand slow-spreading ridges. While the model of a slow-spreading principal magmatic segment is well supported by a diverse suite of observations of the MAR over the past two decades, the model of a fast-spreading principal magmatic segment is more speculative and is based on recent observations from a limited portion of the northern EPR. Figure 14 summarizes inter-segment variations and implications for mantle upwelling and melting for comparison with Figure 1. In the discussion that follows, we first describe the general characteristics of principal magmatic segments and their relationship to mantle processes. We then summarize insights gained from current observations regarding early ideas of spreading cells, hierarchical segmentation, central magma supply beneath ridge segments, and the relationship between geochemical and geophysical indicators of magmatic segmentation. This discussion builds upon the numerous studies cited in the preceding sections: references are included below to support concepts 


\section{SEGMENTATION OF MID-OCEAN RIDGES}

not previously introduced and for the historical discussion of the later section on the concept of spreading cells.

\section{Melt distribution and structure of principal magmatic spreading segments}

Beneath fast-spreading ridges (Figs 13a \& 14a), current geophysical and geological observations suggest that rising mantle melts accumulate and pool at the base of the crust forming discrete melt reservoirs in the uppermost mantle at intervals roughly coincident with third-order tectonic segments. Some focusing of melts within the upper mantle is required to form these localized regions of melt pooling. Within the crust, magma lenses or sills consisting of a few percent to $100 \%$ melt exist as approximately steady state bodies at the top of a lower crustal zone of crystal mush and may also form at mid- and lower-crustal levels within this mush zone. Magma bodies in the crust are further partitioned into lenses that often coincide with the finer (fourth-order) seafloor segmentation of the active eruptive fissure zone. At fast spreading rates, crustal thickness is approximately uniform within these principal magmatic segments. The primary characteristics of principal magmatic segments at fast-spreading ridges depicted in Figure 13a may also be relevant for the magmatically robust portions of intermediate-spreading ridges, although the available data are more limited.

Slow-spreading ridges differ markedly from fast-spreading ridges in crustal and lithospheric structure and in the distribution of melt within each magmatic segment (Figs 13b \& 14b). Strong focusing of mantle melts within each principal magmatic spreading segment (defined by the secondorder segmentation) leads to large variations in crustal thickness $(2-3 \mathrm{~km})$, with thick crust and thin axial lithosphere at segment centres, and thin crust and thick axial lithosphere at segment ends. Crustal magma bodies may form within a segment but are more localized and ephemeral than at fastspreading ridges: melt mush and melt lenses may develop at various levels in the crust and upper mantle lithosphere along the segment but are concentrated primarily near segment centres. At magma-rich segment centres, the magmatic crust is more continuous and layered, but toward the magma-poor segment ends, the magmatic crust becomes progressively thinner and more discontinuous, and lower crustal and upper mantle rocks may be exhumed by large-offset detachment faults. Detachment faults can reach horizontal offsets of many tens of kilometres compared to the shorterlived normal faults commonly formed near segment centres that only extend for a few hundred metres, before being abandoned as a new fault initiates closer to the axis. The more magmatic portions of ultraslow-spreading ridges share the primary features of principal magmatic segments as slow-spreading ridges. The morphological and geological characteristics of the discontinuities that separate magmatic segments at these ridges are diverse and often tectonically complex, particularly at ultraslow ridges.

\section{The concept of spreading cells}

The original concept of a spreading cell developed in the early 1980s from studies of magnetic anomalies of old Atlantic crust was that the MOR is subdivided into quasi-regular segments, each with its own mantle melt supply system at depth (Schouten \& White 1980; Schouten \& Klitgord 1982). Although the offsets between segments (believed at the time to be TFs) could change length and even disappear, the segments persisted as long-lived coherent units. As detailed bathymetric data from the MAR were acquired, it became apparent that this spreading cell segmentation corresponded with what was later classified as the second-order segmentation of the ridge bounded by NTOs (Schouten et al. 1985; Sempéré et al. 1990). The OSCs discovered at fast-spreading ridges were believed to be analogous features bounding similar long-lived spreading cells at the EPR (Macdonald et al. 1984; Schouten et al. 1985). Interpreted spreading cells along the MAR were $c .50 \mathrm{~km}$ in length (Schouten et al. 1985) and somewhat longer along the EPR $(65 \mathrm{~km}$ from Schouten et al. (1985); $145 \mathrm{~km}$ from Macdonald et al. (1992)), although as more of the EPR was mapped in detail, it became apparent that the interpreted spreading cell segmentation did not exhibit the same regularity as along the MAR. Furthermore, a growing body of evidence at fast-spreading ridges argued against a centralized magmatic plumbing system beneath the second-order segments bounded by OSCs.

Observations from many ridge areas surveyed over the 30 years since these early studies reveal a quasi-regular segmentation of the ridge into principal magmatic segments that is analogous to the original notion of spreading cells. At slow-spreading ridges, principal magmatic segments (Fig. 13b) coincide with the second-order segmentation and correspond with the spreading cells as originally interpreted by Schouten and colleagues. Regionalscale studies of the MAR using the Sandwell \& Smith (1997) global bathymetry compilation reveal a range of $20-100 \mathrm{~km}$ and an average length of $50 \mathrm{~km}$ for this segmentation (Briais \& Rabinowicz 2002), consistent with original estimates based on studies of more limited portions of the MAR. Ultraslow-spreading ridges include long melt-poor 


\section{S. M. CARBOTTE ET AL.}

sections with volcanic centres that are separated by larger distances (200 km spacing or more) with nonvolcanic domains between them. Other, probably more magmatic regions of ultraslow ridges, however, have second-order segments that are $c$. 30-100 km long, similar to slow-spreading ridges.

At fast-spreading centres, principal magmatic segments appear to coincide with the third-order tectonic segments of the ridge (Fig. 13a) and not the larger-scale second-order segments originally interpreted as spreading cells. These segments range in length from 20 to $90 \mathrm{~km}$ (average $30 \mathrm{~km}$ for northern EPR), similar to these segments at slow spreading rates. Data from the hotspot-dominated portions of the intermediate-spreading GSC suggest distinct spreading segments with dimensions of $30-120 \mathrm{~km}$, also much shorter than the secondorder segmentation of this ridge. At the intermediate spreading SEIR, second- and some third-order segments may correspond with principal magmatic segments. The regional perspective provided by the Briais \& Rabinowicz (2002) study of satellitederived bathymetry indicates an average length of $50 \mathrm{~km}$ for the primary segmentation of intermediate ridges including the SEIR.

Hence a pattern emerges of principal magmatic segments that are similar in length $(30-50 \mathrm{~km}$ on average) at all spreading rates. The characteristics of these segments inferred from the modern data are distinct from the spreading cells originally proposed by Schouten et al. (1985) and others in that each is linked to a distinct magma plumbing system in the shallowest asthenospheric mantle (e.g. at $>6 \mathrm{~km}$ to $>12 \mathrm{~km}$ depending on spreading rate) although the observations of punctuated melt centres at fast-spreading ridges likely require deeper diapiric upwelling of melts. At fast-spreading ridges the principal magmatic segments inferred from the modern data are present on a finer scale than the spreading cells originally proposed for the EPR, and these cells may be shorter lived at these spreading rates.

\section{Chemical observations and inferences regarding magmatic segmentation}

Geochemical observations from fast-spreading ridges indicate that mantle source compositions and extents of melting typically vary over length scales that are longer than the tectonic segmentation of the ridge defined by TFs and NTOs. However, where abrupt changes in lava chemistry occur that indicate significant differences in source composition or melting processes, they usually coincide with first-, second- or third-order tectonic discontinuities. Yet many tectonic discontinuities show no change in geochemical parameters. This suggests that where chemical discontinuities coincide with offsets along fast-spreading ridges, they may arise from shallow upper mantle melt focusing and crustal melt distribution processes, independent of regional variations in mantle source composition and extents of melting.

Along slow-spreading ridges, magma compositions often vary widely over short spatial scales most likely due to inefficient melt pooling and possible prevalence of small-scale mantle heterogeneities. In the few places where seafloor sampling is sufficient to characterize inter-segment variations, geochemical data show some evidence of differences in composition between adjacent spreading segments, superimposed upon long-wavelength gradients that cross multiple first- and second-order segment boundaries. As for fast-spreading ridges, this is consistent with the notion of upper mantle focusing of melt to individual magmatic spreading segments.

Thus, while there is some correspondence between geochemical and geophysical segmentation of the ridge over a range of spreading rates, existing data suggest these relationships are complex. To be sure, on a global scale, there are strong correlations between geophysical determinations of the volume of melt delivered to the ridge (leading to a given crustal thickness and axial depth) and geochemical determinations of the volume of melt produced by mantle melting (leading to a given melt composition and inferred extent of mantle melting). But in our effort to study axial variations on smaller scales, analysis of geophysical and geochemical data often yields conflicting results. There are likely a number of reasons for this current mismatch. First, much of the geophysical data present a time-averaged view of crustal construction, while geochemical analyses of individual lavas represent a snapshot in time of only a small fraction of the melt that over time will build the crust. Second, geochemical studies show that diverse melt compositions are produced during mantle melting that may pool to greater or lesser extents in different settings. Third, in addition to regional gradients in mantle source composition, the existence of smaller-scale heterogeneities presents significant challenges in our effort to characterize along-axis variations in melting parameters. Yet despite these complexities, there are aspects of magma supply that geochemical studies are uniquely suited to address, because when deciphered, melt compositions reveal their distinctive histories that can be used to track magma transport and distribution.

\section{Is segmentation hierarchical?}

The notion of a hierarchy of nested scales of magmatic segments defined by distinct classes of 


\section{SEGMENTATION OF MID-OCEAN RIDGES}

ridge axis discontinuities was proposed in the late 1980s and has been an influential concept in MOR research. However, the perspective gained from observations of many MOR regions indicates that the applicability of this hierarchical model, with first-order TF bounded segments reflecting deeper mantle upwelling and melting processes, partitioned into smaller segments that share the deep plumbing (Fig. 1), is limited. The prominent along-axis topographic arches present along slow- to ultraslowspreading ridges and some intermediate ridges, which are attributed to along-axis variations in magma supply, occur on the $30-50 \mathrm{~km}$ length scales of principal magmatic segments and not on the longer length scales of the first-order segments (Figs 5, 8, 10). While some TFs do mark major boundaries in geochemical properties, indicating distinct mantle source compositions (e.g. the Romanche and Oceanographer TF along the MAR), such geochemical boundaries also occur at smaller offsets (e.g. the $20^{\circ} 40^{\prime} \mathrm{S}$ OSC on the EPR (Fig. 4), or the $92^{\circ} 40^{\prime} \mathrm{W}$ offset on the GSC (Fig. 7)). Changes in ridge properties, such as axial depth, axial gravity anomalies, crustal thickness and lava chemistry, approaching and near TFs, are often comparable to those observed at smaller offsets (e.g. compare north of the Clipperton TF with north of $20^{\circ} 40^{\prime} \mathrm{S}$ OSC; Figs 2 \& 4). Even very small ridge axis discontinuities can be major regional boundaries in a range of ridge properties (e.g. $92^{\circ} 40^{\prime} \mathrm{W}$ on the GSC; Fig. 7).

There is evidence, however, for larger-scale 'tectonic corridors' that span multiple TF- and NTObounded segments at intermediate and slow ridges and 'super-segments' at ultraslow ridges that may be significant for deeper mantle processes. The obliquity of the ridge relative to spreading direction is also believed to contribute to regional variations at these length scales. In addition, the notion of hierarchical nested scales of segmentation does provide a useful framework for understanding the highest order segmentation at fast- and possibly intermediate-spreading ridges. At these ridges, third-order segments, which appear to coincide with segmentation of melt in the shallowest mantle, are subdivided into smaller fourth-order segments that may primarily reflect partitioning of melt at shallower levels within the crust (Fig. 13a).

\section{Central magma supply beneath spreading segments}

At slow and ultraslow ridges, modern observations confirm early inferences that mantle melt is highly focused beneath the centres of what are now commonly referred to as second-order ridge segments, leading to thicker crust and thinner axial lithosphere within these regions (Fig. 13b). While these observations are consistent with the notion of centralized melt supply, this melt focusing may result from processes in the shallow mantle and does not necessarily require melt diapirs rising from depth as originally proposed by Whitehead, Schouten and others. Large spatial gradients in the thickness of the axial lithosphere are expected both across and along axis at slow and ultraslow ridges (Figs $13 b \& 14 b)$ that may act to efficiently focus mantle melts that migrate along the base of the lithosphere (e.g. Sparks \& Parmentier 1991; Magde \& Sparks 1997). Furthermore, strong positive feedback between pooling of mantle melts and lithospheric structure is expected, and magmatic segmentation could be primarily controlled by spatial variations in lithospheric thickness. While the observations do not rule out some deeper (e.g. $30-50 \mathrm{~km}$ ) organization of mantle upwelling and melting, melt focusing at slow- and ultraslowspreading ridges could thus be largely controlled by the base of the lithosphere (e.g. Montesi et al. 2011).

At fast-spreading ridges, however, lithospheric controls are less likely to account for the local accumulations of mantle melts that have been detected beneath third-order segments by Toomey and colleagues (Fig. 13a). Here, the base of the lithosphere is within or at the base of the crust, along-axis variations in crustal thickness are modest, and hence melt pooling guided by variations in lithospheric thickness should be minimal. At these ridges, variations in asthenospheric mantle upwelling and/or melt segregation processes are likely required to account for the presence of punctuated melt accumulations.

\section{Questions for future work}

Current observations suggest that a primary tectonic and magmatic segmentation of the MOR system exists arising from the relatively regular distribution of mantle melt within the shallow asthenosphere with a characteristic length scale of $30-50 \mathrm{~km}$. This inference is derived from multi-disciplinary studies that have been conducted in a few select regions: clearly, future studies at a spectrum of sites will be required to test this interpretation. Critical areas for future study pertaining to this notion of principal magmatic segments at all spreading rates include: 3D studies of the segment-scale distribution of melt in the asthenospheric mantle beneath ridges over a range of spreading rates; detailed multi-segment geochemical and geological studies along slow- and ultraslow-spreading ridges; and new modelling studies to explore the origin of the quasi-regular segmentation at all spreading rates and the significance of deeper mantle processes in their development. 


\section{S. M. CARBOTTE ET AL.}

Other important questions not touched upon in this review include: how segments initiate (e.g. Bird \& Naar 1994; Cormier et al. 1996); the role of lateral magma transport in the crust and mantle (e.g. Macdonald et al. 1984; Fox et al. 1995; Batiza 1996); the contribution of small upper mantle melt anomalies to segmentation (e.g. Gomez \& Briais 2000); how discontinuities evolve and grow, in particular the relationship between second- and third-order offsets at fast and intermediate ridges (e.g. Carbotte \& Macdonald 1992; Cormier et al. 1996; Canales et al. 2002); and what drives the migration of these discontinuities (e.g. Macdonald et al. 1984, 1988; Schouten et al. 1987; Tucholke \& Schouten 1988; Lonsdale 1989, 1994; Cormier 1997). Some of the critical needs pertaining to these areas of active research include: integrated geophysical and geochemical studies that target the ridge flanks to understand the processes that cause magmatic segments to initiate, migrate and evolve through time; long-term multi-segment-scale microseismicity monitoring studies with OBS arrays to detect and characterize magma transport in the crust; and geochemical and geochronological studies of both the ridge axis and flanks to explore changes in melt composition as ridge segments evolve.

Thanks to many colleagues for stimulating discussions and for providing data, including Ken Macdonald, Mike Perfit, Charlie Langmuir, Pablo Canales, Milene Cormier, Javier Escartin and Daniel Sauter. We also thank Cindy Ebinger and Charlie Langmuir for their helpful reviews which contributed to a much improved paper.

\section{References}

Aghaei, O., Nedimović, M. R., Carton, H., Carbotte, S. M., Canales, J. P. \& Mutter, J. C. 2014. Crustal thickness and Moho character of the fast-spreading East Pacific Rise from $9^{\circ} 42^{\prime} \mathrm{N}$ to $9^{\circ} 57^{\prime} \mathrm{N}$ from poststack-migrated 3-D MCS data. Geochemistry, Geophysics, Geosystems, 15, 634-657.

Babcock, J. M., Harding, A. J., Kent, G. M. \& Orcutt, J. A. 1998. An examination of along-axis variation of magma chamber width and crustal structure on the East Pacific Rise between $1330^{\prime} \mathrm{N}$ and $1220^{\prime} \mathrm{N}$. Journal of Geophysical Research, 103, $30451-30467$.

Baines, A. G., Cheadle, M. J., John, B. E. \& Schwartz, J. J. 2008. The rate of oceanic detachment faulting at Atlantis Bank, SW Indian Ridge. Earth and Planetary Science Letters, 273, 105-114.

Ballard, R. D. \& VAN Andel, T. H. 1977. Morphology and tectonics of the inner rift valley at lat. $36^{\circ} 50^{\prime} \mathrm{N}$ on the Mid-Atlantic Ridge. Geological Society of America Bulletin, 88, 507-530.

Baran, J. M., Cochran, J. R., Carbotte, S. M. \& NediMović, M. R. 2005. Variations in upper crustal structure due to variable mantle temperature along the
Southeast Indian Ridge. Geochemistry Geophysics Geosystems, 6, Q11002.

Barclay, A. H., Toomey, D. R. \& Solomon, S. C. 2001. Microearthquake characteristics and crustal $\mathrm{Vp} / \mathrm{Vs}$ structure at the Mid-Atlantic Ridge, $35^{\circ}$ N. Journal of Geophysical Research, 106, 2017-2034.

BARTH, G. A. \& MutTER, J. C. 1996. Variability in oceanic crustal thickness and structure: multichannel seismic reflection results from the northern East Pacific Rise. Journal of Geophysical Research, 101, 17 951-17 975, http://dx.doi.org/10.1029/96JB00814

Barth, G. A., Kastens, K. A. \& Klein, E. M. 1994. The origin of bathymetric highs at ridge-transform intersections: a multi-disciplinary case study at the Clipperton Fracture Zone. Marine Geophysical Researches, 16, $1-50$.

BatiZA, R. 1996. Magmatic segmentation of mid-ocean ridges: a review. In: MACLEOD, C. J., Tyler, P. A. \& WALKer, C. L. (eds) Tectonic, Magmatic, Hydrothermal and Biological Segmentation of Mid-Ocean Ridges. Geological Society, London, Special Publications, 118, 103-130, http://dx.doi.org/10.1144/ GSL.SP.1996.118.01.06

Batiza, R., Melson, W. G. \& O'Hearn, T. 1988. Simple magma supply geometry inferred beneath a segment of the Mid-Atlantic Ridge. Nature, 335, 428-431.

Batiza, R., Niu, Y., Karsten, J. L., Boger, W., Potts, E., Norby, L. \& Butler, R. 1996. Steady and nonsteady state magma chambers below the East Pacific Rise. Geophysical Research Letters, 23, 221-224.

Bazin, S., van Avendonk, H., Harding, A. J., Orcutt, J. A., Canales, J. P. \& Detrick, R. S. 1998. Crustal structure of the flanks of the East Pacific Rise: implications for overlapping spreading centers. Geophysical Research Letters, 25, 2213-2216.

Bender, J. F., Langmuir, C. H. \& Hanson, G. N. 1984. Petrogenesis of basalt glasses from the Tamayo region, East Pacific Rise. Journal of Petrology, 25, 213-254.

Bergmanis, E. C., Sinton, J. \& Rubin, K. H. 2007. Recent eruptive history and magma reservoir dynamics on the southern East Pacific Rise at 17 30' S. Geochemistry, Geophysics, Geosystems, 8, http://dx.doi.org/ 10.1029/2007GC001742

BIRD, R. T. \& NAAR, D. F. 1994. Intratransform origins of mid-ocean ridge microplates. Geology, 22, 987-990.

Blacic, T. M., Ito, G., Canales, J. P., Detrick, R. S. \& SinTon, J. 2004. Constructing the crust along the Galapagos Spreading Center 91.3-95.5 W: correlation of seismic layer $2 \mathrm{~A}$ with axial magma lens and topographic characteristics. Journal of Geophysical Research, 109, B10310.

Blackman, D. K. \& Forsyth, D. W. 1991. Isostatic compensation of tectonic features of the Mid-Atlantic Ridge: $25^{\circ}-27^{\circ} 30^{\prime}$ S. Journal of Geophysical Research, 96, $11741-11758$.

Blackman, D. K., Karner, G. D. \& Searle, R. C. 2008. Three-dimensional structure of oceanic core complexes: effects on gravity signature and ridge flank morphology, Mid-Atlantic Ridge, $30^{\circ}$ N. Geochemistry, Geophysics, Geosystems, 9, http://dx.doi.org/10. 1029/2008GC001951

Blichert-Toft, J., Agranier, A., Andres, M., KingsLey, R., Schilling, J. G. \& Albarède, F. 2005. 


\section{SEGMENTATION OF MID-OCEAN RIDGES}

Geochemical segmentation of the Mid-Atlantic Ridge north of Iceland and ridge-hot spot interaction in the North Atlantic. Geochemistry, Geophysics, Geosystems, 6, Q01E19.

Briais, A. \& Rabinowicz, M. 2002. Temporal variations of the segmentation of slow to intermediate spreading mid-ocean ridges 1 . Synoptic observations based on satellite altimetry data. Journal of Geophysical Research, 107, 2098.

Bonatti, E., Ligi, M., Gasperini, L., Peyve, A., RaznitSIN, Y. \& CHEN, Y. J. 1994. Transform migration and vertical tectonics at the Romanche fracture zone, equatorial Atlantic. Journal of Geophysical Research, 99, $21779-21802$.

Bonatti, E., Fabretti, P., Ligi, M., Portaro, R. A. \& SEYLER, M. 2001. Steady-state creation of crustfree lithosphere at cold spots in mid-ocean ridges. Geology, 29, 979-982.

Buck, W. R. 2005. Flexural rotation of normal faults. Tectonics, 7, 959-973.

Buck, W. R., Lavier, L. L. \& Poliakov, A. N. B. 2005. Modes of faulting at mid-ocean ridges. Nature, 434, 719-723.

Calvert, A. J. 1995. Seismic evidence for a magma chamber beneath the slow-spreading Mid-Atlantic Ridge. Nature, 377, 410-414.

Canales, J. P., Detrick, R. S., Bazin, S., Harding, A. J. \& ORCUTT, J. A. 1998. Off-axis crustal thickness across and along the East Pacific Rise within the MELT area. Science, 280, 1218-1221.

Canales, J. P., Detrick, R. S., Lin, J., Collins, J. A. \& ToomeY, D. R. 2000. Crustal and upper mantle seismic structure beneath the rift mountains and across a nontransform offset at the Mid-Atlantic Ridge $\left(35^{\circ} \mathrm{N}\right)$ Journal of Geophysical Research, 105, 2699-2719.

Canales, J. P., Ito, G., Detrick, R. S. \& Sinton, J. 2002. Crustal thickness along the western Galapagos Spreading Center and the compensation of the Galapagos hotspot swell. Earth and Planetary Science Letters, 203, 311-327.

Canales, J. P., Detrick, R. S., Toomey, D. R. \& WiLcock, W. S. D. 2003. Segment-scale variations in crustal structure of $150-300$-kyr old fast spreading oceanic crust (East Pacific Rise, $8^{\circ} 15^{\prime} \mathrm{N}-10^{\circ} 15^{\prime} \mathrm{N}$ ) from wide-angle seismic refraction profiles. Geophysical Journal International, 152, 766-794.

Cannat, M. 1993. Emplacement of mantle rocks in the seafloor at mid-ocean ridges. Journal of Geophysical Research, 98, 4163-4172.

Cannat, M., Mevel, C. ET AL. 1995. Thin crust, ultramafic exposures, and rugged faulting patterns at the Mid-Atlantic Ridge $\left(22^{\circ}-24^{\circ} \mathrm{N}\right)$. Geology, 23, 49-52.

Cannat, M., Rommevaux-Jestin, C., Sauter, D., Deplus, C. \& Mendel, V. 1999. Formation of the axial relief at the very slow spreading Southwest Indian Ridge (49 to 69 E). Journal of Geophysical Research, 104, 22825.

Cannat, M., Rommevaux-Jestin, C. \& Fujimoto, H. 2003. Melt supply variations to a magma-poor ultraslow spreading ridge (Southwest Indian Ridge 61 to 69 E). Geochemistry Geophysics Geosystems, 4, 9104.

Cannat, M., Sauter, D. ET AL. 2006. Modes of seafloor generation at a melt-poor ultraslow-spreading ridge. Geology, 34, 605-608.
Cannat, M., Sauter, D., Bezos, A., Meyzen, C., Humler, E. \& Le Rigoleur, M. 2008. Spreading rate, spreading obliquity, and melt supply at the ultraslow spreading Southwest Indian Ridge. Geochemistry, Geophysics, Geosystems, 9, Q04002.

Cannat, M., Sauter, D., Escartín, J., Lavier, L. \& PICAZO, S. 2009. Oceanic corrugated surfaces and the strength of the axial lithosphere at slow spreading ridges. Earth and Planetary Science Letters, 288, 174-183.

Carbotte, S. M. \& Macdonald, K. C. 1992. East Pacific Rise $8^{\circ}-10^{\circ} 30^{\prime} \mathrm{N}$; evolution of ridge segments and discontinuities from SeaMarc II and three-dimensional magnetic studies. Journal of Geophysical Research, 97, 6959-6982.

Carbotte, S. M., Ponce-Correa, G. \& Solomon, A. 2000. Evaluation of morphological indicators of magma supply and segmentation from a seismic reflection study of the EPR $15^{\circ} 30-17^{\circ} \mathrm{N}$. Journal of Geophysical Research, 105, 2737-2759.

Carbotte, S. M., Small, C. \& Donnelly, K. 2004. The influence of ridge migration on the magmatic segmentation of mid-ocean ridges. Nature, 429, $743-746$.

Carbotte, S. M., Marjanović, M. et al. 2013. Finescale segmentation of the crustal magma reservoir beneath the East Pacific Rise. Nature Geoscience, 6 , $866-870$.

Castillo, P. R., Klein, E., Bender, J., Langmuir, C., Shirey, S., Batiza, R. \& White, W. 2000. Petrology and $\mathrm{Sr}, \mathrm{Nd}$, and $\mathrm{Pb}$ isotope geochemistry of mid-ocean ridge basalt glasses from the $1145^{\prime} \mathrm{N}$ to $1500^{\prime} \mathrm{N}$ segment of the East Pacific Rise. Geochemistry, Geophysics, Geosystems, 1, http://dx.doi.org/10.1029/ 1999GC000024

Chen, Y. \& Morgan, W. J. 1990. Rift valley/no rift valley transition at mid-ocean ridges. Journal of Geophysical Research, 95, 17571-17581.

Christie, D. M. \& Sinton, J. M. 1981. Evolution of abyssal lavas along propagating segments of the Galapagos spreading center. Earth and Planetary Science Letters, 56, 321-335.

Christie, D. M., West, B. P., Pyle, D. G. \& Hanan, B. B. 1998. Chaotic topography, mantle flow and mantle migration in the Australian-Antarctic discordance. Nature, 394, 637-644.

Christie, D. M., Werner, R., Hauff, F., Hoernle, K. \& HaNAN, B. B. 2005. Morphological and geochemical variations along the eastern Galápagos Spreading Center. Geochemistry, Geophysics, Geosystems, 6, http://dx.doi.org/10.1029/2004GC000714

Cochran, J. R. 2008. Seamount volcanism along the Gakkel Ridge, Arctic Ocean. Geophysical Journal International, 174, 1153-1173, http://dx.doi.org/10. 1111/j.1365-246X.2008.03860.x

Cochran, J. R. \& Sempéré, J. C. 1997. The Southeast Indian Ridge between $88 \mathrm{E}$ and $118 \mathrm{E}$ : gravity anomalies and crustal accretion at intermediate spreading rates. Journal of Geophysical Research, 102 , $15463-15487$.

Cochran, J., Kurras, G., Edwards, M. \& Coakley, B. 2003. The Gakkel Ridge: bathymetry, gravity anomalies, and crustal accretion at extremely slow spreading rates. Journal of Geophysical Research, 108, 2116. 


\section{S. M. CARBOTTE ET AL.}

Colman, A., Sinton, J. M. ET AL. 2012. Effects of variable magma supply on mid-ocean ridge eruptions: constraints from mapped lava flow fields along the Galápagos Spreading Center. Geochemistry, Geophysics, Geosystems, 13, http://dx.doi.org/10.1029/ 2012GC004163

Combier, V., Singh, S. C., Cannat, M. \& Escartin, J. 2008. Mechanical decoupling and thermal structure at the East Pacific Rise axis $9^{\circ} \mathrm{N}$ : constraints from axial magma chamber geometry and seafloor structures. Earth and Planetary Science Letters, 272, 19-28.

Coogan, L. A., Saunders, A. D., Kempton, P. D. \& Norry, M. J. 2000. Evidence from oceanic gabbros for porous melt migration within a crystal mush beneath the Mid-Atlantic Ridge. Geochemistry, Geophysics, Geosystems, 1, http://dx.doi.org/10.1029/ 2000GC000072

Cormier, M. H. 1997. The ultrafast East Pacific Rise: instability of the plate boundary and implications for accretionary processes. Philosophical Transactions of the Royal Society of London. Series A: Mathematical, Physical and Engineering Sciences, 355, 341-367.

Cormier, M. H., Macdonald, K. C. \& Wilson, D. S. 1995. A three-dimensional gravity analysis of the East Pacific Rise from 18 to $2130^{\prime}$ S. Journal of Geophysical Research, 100, 8063-8082.

Cormier, M. H., Scheirer, D. S. \& Macdonald, K. C. 1996. Evolution of the East Pacific Rise at $16^{\circ}-19^{\circ} \mathrm{S}$ since $5 \mathrm{Ma}$ : bisection of overlapping spreading centers by new, rapidly propagating ridge segments. Marine Geophysical Researches, 18, 53-84.

Cormier, M. H., Gans, K. D. \& Wilson, D. S. 2011. Gravity lineaments of the Cocos Plate: evidence for a thermal contraction crack origin. Geochemistry, Geophysics, Geosystems, 12, http://dx.doi.org/10.1029/ 2011GC003573

Crane, K. 1985. The spacing of rift axis highs: dependence upon diapiric processes in the underlying asthenosphere? Earth and Planetary Science Letters, 72, 405-414.

Crawford, W. C. \& WebB, S. C. 2002. Variations in the distribution of magma in the lower crust and at the Moho beneath the East Pacific Rise at $9^{\circ}-10^{\circ} \mathrm{N}$. Earth and Planetary Science Letters, 203, 117-130.

Cushman, B., Sinton, J., Ito, G. \& Eaby Dixon, J. 2004. Glass compositions, plume-ridge interaction, and hydrous melting along the Galápagos Spreading Center, $90.5^{\circ} \mathrm{W}$ to $98^{\circ} \mathrm{W}$. Geochemistry, Geophysics, Geosystems, 5, http://dx.doi.org/10.1029/2004GC 000709

de Martin, B., Sohn, R., Canales, J. P. \& Humphris, S. 2007. Kinematics and geometry of active detachment faulting beneath the Trans-Atlantic Geotraverse (TAG) hydrothermal field on the Mid-Atlantic Ridge. Geology, 35, 711.

DeMets, C., Gordon, R. G., Argus, D. F. \& Stein, S. 1994. Effect of recent revisions to the geomagnetic reversal time scale on estimates of current plate motions. Geophysical Research Letters, 21, 2191-2194.

Detrick, R. S., Buhl, P., Vera, E. E., Mutter, J. C., Orcutt, J. A., Madsen, J. A. \& Brocher, T. M. 1987. Multi-channel seismic imaging of a crustal magma chamber along the East Pacific Rise. Nature, 326, 35-41.

Detrick, R. S., Mutter, J. C., Buhl, P. \& Kim, I. I. 1990. No evidence from multichannel reflection data for a crustal magma chamber in the MARK area on the MidAtlantic Ridge. Nature, 347, 61-64.

Detrick, R. S., Harding, A. J., Kent, G. M., Orcutt, J. A., Mutter, J. C. \& Buhl, P. 1993. Seismic structure of the southern East Pacific Rise. Science, 259, 499-503.

Detrick, R. S., Needham, H. D. \& Renard, V. 1995. Gravity anomalies and crustal thickness variations along the Mid-Atlantic Ridge between $33 \mathrm{~N}$ and $40 \mathrm{~N}$. Journal of Geophysical Research, 100, 3767-3787.

Detrick, R. S., Sinton, J. M. et AL. 2002. Correlated geophysical, geochemical, and volcanological manifestations of plume-ridge interaction along the Galápagos Spreading Center. Geochemistry, Geophysics, Geosystems, 3, 1-14.

Dick, H. J. B. 1989. Abyssal peridotites, very slow spreading ridges and ocean ridge magmatism. In: SAUNDERS, A. D. \& Norry, M. J. (eds) Magmatism in the Ocean Basins. Geological Society, London, Special Publications, 42, 71-105, http://dx.doi.org/10.1144/ GSL.SP.1989.042.01.06

Dick, H., Lin, J. \& Schouten, H. 2003. An ultraslowspreading class of ocean ridge. Nature, 426, 405-412.

Dick, H. J. B., Thompson, G. \& Bryan, W. B. 1981. Lowangle faulting and steady-state emplacement of plutonic rocks at ridge-transform intersections. Eos Transactions of the AGU, 62, 406.

Donnelly, K. 2002. The Genesis of E-MORB: Extensions \& Limitations of the Hot Spot Model. PhD thesis, Columbia University.

Dosso, L., Bougault, H., Langmuir, C., Bollinger, C., Bonnier, O. \& Etoubleau, J. 1999. The age and distribution of mantle heterogeneity along the MidAtlantic Ridge (31-41 N). Earth and Planetary Science Letters, 170, 269-286.

Dunn, R. A., Toomey, D. R. \& Solomon, S. C. 2000. Three-dimensional seismic structure and physical properties of the crust and shallow mantle beneath the East pacific Rise at $9^{\circ} 30^{\prime} \mathrm{N}$. Journal of Geophysical Research, 105, 23 537-23 555.

Dunn, R. A., Lekić, V., Detrick, R. S. \& Toomey, D. R. 2005. Three-dimensional seismic structure of the MidAtlantic Ridge $\left(35^{\circ} \mathrm{N}\right)$ : evidence for focused melt supply and lower crustal dike injection. Journal of Geophysical Research, 110, B09101.

Dunn, R. A., Toomey, D. R., Detrick, R. S. \& Wilcock, W. S. 2001. Continuous mantle melt supply beneath an overlapping spreading center on the East Pacific Rise. Science, 291, 1955-1958.

Dziak, R. P., Fox, C. G., Smith, D. K., Matsumoto, H., Bohnenstiehl, D., HaXel, J. \& Fowler, M. 2002. Evidence of probable magmatic episode at the Lucky Strike Setment, Mid-Atlantic Ridge, March 2001. InterRidge News, 11, 29-31.

EsCARTÍn, J. \& Lin, J. 1995. Ridge offsets, normal faulting, and gravity anomalies of slow spreading ridges. Journal of Geophysical Research, 100, 6163-6177.

Escartín, J., Smith, D. K., Cann, J., Schouten, H., LANGMuir, C. H. \& Escrig, S. 2008. Central role of detachment faults in accretion of slow-spread oceanic lithosphere. Nature, 455, 790-794, http://dx.doi.org/ 10.1038 /nature 07333

Fornari, D. J., Haymon, R. M., Perfit, M. R., GregG, T. K. P. \& Edwards, M. H. 1998. Axial summit 


\section{SEGMENTATION OF MID-OCEAN RIDGES}

trough of the East Pacific Rise $9^{\circ}-10^{\circ} \mathrm{N}$ : geological characteristics and evolution of the axial zone on fast spreading mid-ocean ridges. Journal of Geophysical Research, 103, 9827-9855.

ForSYTH, D. W. 1992. Geophysical constraints on mantle flow and melt generation beneath mid-ocean ridges in Morgan. In: Phipps Morgan, J., Blackman, D. K. \& Sinton, J. M. (eds) Mantle Flow and Melt Generation at Mid-Ocean Ridges. American Geophysical Union Monograph, 71, 1-65, http://dx.doi.org/10. 1029/GM071p0001

Forsyth, D. W. \& Wilson, B. 1984. Three-dimensional temperature structure of a ridge-transform-ridge system. Earth and Planetary Science Letters, 70, 355-362.

Fox, C. G., Radford, W. E., DziaK, R. P., LaU, T. K., Matsumoto, H. \& Schreiner, A. E. 1995. Acoustic detection of a seafloor spreading episode on the Juan de Fuca Ridge using military hydrophone arrays. Geophysical Research Letters, 22, 131-134.

Fox, P. J. \& Gallo, D. G. 1984. A tectonic model for ridge-transform-ridge plate boundaries: implications for the structure of oceanic lithosphere. Tectonophysics, 104, 205-242.

Francheteau, J. \& Ballard, R. D. 1983. The East Pacific Rise near $21 \mathrm{~N}, 13 \mathrm{~N}$ and $20 \mathrm{~S}$ : inferences for along-strike variability of axial processes of the midocean ridge. Earth and Planetary Science Letters, 64, 93-116.

Gale, A., Escrig, S., Gier, E. J., Langmuir, C. H. \& GoldsteIn, S. L. 2011. Enriched basalts at segment centers: the Lucky Strike $\left(37^{\circ} 17^{\prime} \mathrm{N}\right)$ and Menez Gwen $\left(37^{\circ} 50^{\prime} \mathrm{N}\right)$ segments of the Mid-Atlantic Ridge. Geochemistry, Geophysics, Geosystems, 12, http:// dx.doi.org/10.1029/2010GC003446

Gale, A., Laubier, M., Escrig, S. \& Langmuir, C. H. 2013. Constraints on melting processes and plume-ridge interaction from comprehensive study of the FAMOUS and North Famous segments, MidAtlantic Ridge. Earth and Planetary Science Letters, 365, 209-220.

Gente, P., Pockalny, R. A. et al. 1995. Characteristics and evolution of the segmentation of the Mid-Atlantic Ridge between $20^{\circ} \mathrm{N}$ and $24^{\circ} \mathrm{N}$ during the last 10 million years. Earth and Planetary Science Letters, 129, 55-71.

Georgen, J., Lin, J. \& Dick, H. 2001. Evidence from gravity anomalies for interactions of the Marion and Bouvet hotspots with the Southwest Indian Ridge: effects of transform offsets. Earth and Planetary Science Letters, 187, 283-300.

GoFf, J. A. 1991. A global and regional stochastic analysis of near-ridge abyssal hill morphology. Journal of Geophysical Research, 96, 21 713-21 737.

Goff, J. A., Ma, Y., Shah, A., Cochran, J. R. \& Sempéré, J. C. 1997. Stochastic analysis of seafloor morphology on the flank of the Southeast Indian Ridge: the influence of ridge morphology on the formation of abyssal hills. Journal of Geophysical Research, 102, 15 521-15 534.

Goldstein, S. L., Soffer, G., Langmuir, C. H., Lehnert, K. A., Graham, D. W. \& Michael, P. J. 2008. Origin of a "Southern Hemisphere" geochemical signature in the Arctic upper mantle. Nature, 453, 89-93, http://dx.doi.org/10.1038/nature06919
GomeZ, O. \& BRIAIS, A. 2000. Near-axis seamount distribution and its relationship with the segmentation of the East Pacific Rise and northern Pacific-Antarctic Ridge, $17^{\circ} \mathrm{N}-56^{\circ} \mathrm{S}$. Earth and Planetary Science Letters, 175, 233-246.

Goss, A. R., Perfit, M. R. et AL. 2010. Geochemistry of lavas from the 2005-2006 eruption at the East Pacific Rise, $946^{\prime} \mathrm{N}-956^{\prime} \mathrm{N}$ : Implications for ridge crest plumbing, decadal changes in magma chamber compositions. Geochemistry, Geophysics, Geosystems, 11, Q05T09, http://dx.doi.org/10.1029/2009GC 002977

Gràcia, E., Charlou, J. L., Radford-Knoery, J. \& PARSON, L. M. 2000. Non-transform offsets along the Mid-Atlantic Ridge south of the Azores $\left(38^{\circ} \mathrm{N}-\right.$ $34^{\circ} \mathrm{N}$ ): ultramafic exposures and hosting of hydrothermal vents. Earth and Planetary Science Letters, 177, 89-103.

Graham, D. W., Blichert-Toft, J., Russo, C. J., Rubin, K. \& Albarède, F. 2006. Cryptic striations in the upper mantle revealed by hafnium isotopes in Southeast Indian Ridge basalts. Nature, 440, 199-202.

GregG, P. M., Lin, J., Behn, M. D. \& Montési, L. G. 2007. Spreading rate dependence of gravity anomalies along oceanic transform faults. Nature, 448, 183-187.

Grimes, C. B., John, B. E., Cheadle, M. J. \& Wooden, J. L. 2008. Protracted construction of gabbroic crust at a slow spreading ridge: constraints from $206 \mathrm{~Pb} / 238 \mathrm{U}$ zircon ages from Atlantis Massif and IODP Hole U1309D $\left(30^{\circ} \mathrm{N}\right.$, MAR). Geochemistry Geophyics Geosystems, 9, Q08012, http://dx.doi.org/10.1029/ 2008GC002063

Grindlay, N. R., Fox, P. J. \& Macdonald, K. C. 1991. Second-order ridge axis discontinuities in the south Atlantic: morphology, structure, and evolution. Marine Geophysical Researches, 13, 21-49.

Grindlay, N. R., MadSen, J., Rommevaux-Jestin, C. \& SClATER, J. 1998. A different pattern of ridge segmentation and mantle Bouguer gravity anomalies along the ultra-slow spreading Southwest Indian Ridge ( $1530^{\prime} \mathrm{E}$ to $25 \mathrm{E})$. Earth and Planetary Science Letters, 161, 243-253.

Grove, T. L., Kinzler, R. J. \& Bryan, W. B. 1993. Fractionation of mid-ocean ridge basalt (MORB). In: Phipps Morgan, J., Blackman, D. K. \& Sinton, J. M. (eds) Mantle Flow and Melt Generation at MidOcean Ridges. American Geophysical Union Monograph, 71, 281-310.

Han, S., Carbotte, S. M., Carton, H., Mutter, J. M., Aghaei, O., Nedimovic, M. \& Canales, J. P. 2014. Architecture of on and off-axis magma bodies at EPR $9 ? 37-40^{\prime} \mathrm{N}$ and implications for oceanic crustal accretion, in review. Earth and Planetary Science Letters, 390, 31-44.

Hanan, B. B., Blichert-Toft, J., Hemond, C., Sayit, K., Agranier, A., Graham, D. W. \& Albarède, F. 2013. $\mathrm{Pb}$ and $\mathrm{Hf}$ isotope variations along the Southeast Indian Ridge and the dynamic distribution of MORB source domains in the upper mantle. Earth and Planetary Science Letters, 375, 196-208.

Hayes, D. E. \& Kane, K. A. 1994. Long-lived mid-ocean ridge segmentation of the Pacific-Antarctic Ridge and the Southeast Indian Ridge. Journal of Geophysical Research, 99, 19 679-19692. 


\section{S. M. CARBOTTE ET AL.}

Hayman, N. W., Grindlay, N. R., Perfit, M. R., Mann, P., Leroy, S. \& de LéPINAY, B. M. 2011. Oceanic core complex development at the ultraslow spreading Mid-Cayman Spreading Center. Geochemistry Geophysics Geosystems, 12, http://dx.doi.org/10.1029/ 2010GC003240

Haymon, R. M. \& White, S. M. 2004. Fine-scale segmentation of volcanic/hydrothermal systems along fast-spreading ridge crests. Earth and Planetary Science Letters, 226, 367-382.

Haymon, R. M., Fornari, D. J., Edwards, M., Carbotte, S. M., Wright, D. \& MaCDONALD, K. C. 1991. Hydrothermal Vent Distribution Along the East Pacific Rise Crest $\left(9^{\circ} 09^{\prime}-9^{\circ} 54^{\prime} \mathrm{N}\right)$ and its Relationship to Magmatic and Tectonic Processes on Fast Spreading MidOcean Ridges. Earth and Planetary Science Letters, 104, 513-534.

Hebert, L. B. \& Montési, L. G. 2011. Melt extraction pathways at segmented oceanic ridges: application to the East Pacific Rise at the Siqueiros transform. Geophysical Research Letters, 38, http://dx.doi.org/10. 1029/2011GL047206

Hey, R. 1977. A new class of "pseudofaults" and their bearing on plate tectonics: a propagating rift model. Earth and Planetary Science Letters, 37, 321-325.

Hey, R., Duennebier, F. K. \& Morgan, W. J. 1980. Propagating rifts on midocean ridges. Journal of Geophysical Research, 85, 3647-3658.

Holmes, R. C., Tolstoy, M., Cochran, J. R. \& Floyd, J. S. 2008. Crustal thickness variations along the Southeast Indian Ridge (100-116 E) from 2-D body wave tomography. Geochemistry, Geophysics, Geosystems, 9 , http://dx.doi.org/10.1029/2008GC002152

Hooft, E. E., Detrick, R. S. \& Kent, G. M. 1997. Seismic structure and indicators of magma budget along the southern East Pacific Rise. Journal of Geophysical Research, 102, 27 319-27 340.

Hooft, E. E. E., Detrick, R. S., Toomey, D. R., Collins, J. A. \& LiN, J. 2000. Crustal thickness and structure along three contrasting spreading segments of the MidAtlantic Ridge, $33.5^{\circ}-35^{\circ}$ N. Journal of Geophysical Research, 105, 8205-8226.

Ingle, S., Ito, G., Mahoney, J. J., Chazey, W., Sinton, J., Rotella, M. \& Christie, D. M. 2010. Mechanisms of geochemical and geophysical variations along the western Galápagos Spreading Center. Geochemistry, Geophysics, Geosystems, 11, http://dx.doi.org/10. 1029/2009GC002694

Jian, H., Singh, S., Chen, Y. \& Li, J. 2014. Imaging of lower-crustal magma chambers at an ultraslow spreading ridge segment using elastic waveform inversion of a sparse OBS dataset. EOS Transactions of the AGU, V31B-4752, https://agu.confex.com/agu/fm14/meet ingapp.cgi\#Paper $/ 21646$

JokAt, W. \& Schmidt-Aursch, M. C. 2007. Geophysical characteristics of the ultraslow spreading Gakkel Ridge, Arctic Ocean. Geophysical Journal International, 168, 983-998, http://dx.doi.org/10.1111/ j.1365-246X.2006.03278.X

Jokat, W., Ritzmann, O., Schmidt-Aursch, M., Drachev, S., Gauger, S. \& Snow, J. 2003. Geophysical evidence for reduced melt production on the Arctic ultraslow Gakkel mid-ocean ridge. Nature, 423, 962-965.
Jokat, W., Kollofrath, J., Geissler, W. H. \& Jensen, L. 2012. Crustal thickness and earthquake distribution south of the Logachev Seamount, Knipovich Ridge. Geophysical Research Letters, 39, http://dx.doi.org/ 10.1029/2012GL051199

Kane, K. A. \& Hayes, D. E. 1992. Tectonic corridors in the south Atlantic: evidence for long-lived mid-ocean ridge segmentation. Journal of Geophysical Research: Solid Earth (1978-2012), 97, 17 317-17 330.

KARson, J. A. 1990. Seafloor spreading on the MidAtlantic Ridge: implications for the structure of ophiolites and oceanic lithosphere produced in slowspreading environments. In: Malpas, J., MoOres, E. M., Panayiotou, A. \& Xenophontos, C. (eds) Proceedings of the Symposium TROODOS 1987. Geological Survey Department, Nicosia, Cyprus, 547-555.

Kashintsev, G. L., Shreider, A. A., Maksimochkin, V. I., Bulychev, A. A. \& Gilod, D. A. 2008. Transtension and alkaline magmatism of the Romanche Fracture Zone. Geotectonics, 42, 318-323.

Katz, R. F., Spiegelman, M. \& Carbotte, S. M. 2004. Ridge migration, asthenospheric flow and the origin of magmatic segmentation in the global mid-ocean ridge system. Geophysical Research Letters, 31, http://dx.doi.org/10.1029/2004GL020388

Kelemen, P. B. \& Aharonov, E. 1998. Periodic formation of magma fractures and generation of layered gabbros in the lower crust beneath oceanic spreading ridges. In: Buck, R., Delaney, P. T., Karson, J. A. \& Lagabrielle, Y. (eds) Faulting and Magmatism at Mid-Ocean Ridges, American Geophysical Union, Washington, DC, Geophysical Monograph Series 106, 267-289.

Kelemen, P. B., Shlmlzu, N. \& Salters, V. J. 1995. Extraction of mid-ocean-ridge basalt from the upwelling mantle by focused flow of. Nature, 375, 747-753.

Kent, G. M., Harding, A. J. \& Orcutt, J. A. 1993. Distribution of magma beneath the East Pacific Rise between the Clipperton transform and the $9^{\circ} 17^{\prime} \mathrm{N}$ Deval from forward modeling of Common Depth Point data. Journal of Geophysical Research, 98, $13945-13969$.

Kent, G. M., Singh, S. C. ET AL. 2000. Evidence from three-dimensional seismic reflectivity images for enhanced melt supply beneath mid-ocean ridge discontinuities. Nature, 406, 614-618.

Klein, E. M. \& Langmuir, C. H. 1987. Global correlations of ocean ridge basalt chemistry with axial depth and crustal thickness. Journal of Geophysical Research, 92, 8089-8115.

Klein, E. M., Langmuir, C. H. \& Staudigel, H. 1991. Geochemistry of basalts from the Southeast Indian Ridge, $115^{\circ} \mathrm{E}-138^{\circ} \mathrm{E}$. Journal of Geophysical Research, 96, 2089-2107.

Klein, E. M., White, S. M., Nunnery, J. A., MasonStack, J. L., Wanless, V. D., Perfit, M. R. \& Ridley, W. I. 2013. Seafloor photo-geology and sonar terrain modeling at the $9^{\circ} \mathrm{N}$ overlapping spreading center, East Pacific Rise. Geochemistry, Geophysics, Geosystems, 14, 5146-5170.

Kong, L. S., Solomon, S. C. \& Purdy, G. M. 1992. Microearthquake Characteristics of a Mid-Ocean 


\section{SEGMENTATION OF MID-OCEAN RIDGES}

Ridge along-axis high. Journal of Geophysical Research, 97, 1659-1685.

KUO, B. Y. \& ForsYTH, D. W. 1988. Gravity anomalies of the ridge-transform system in the South Atlantic between $31^{\circ}$ and $34.5^{\circ} \mathrm{S}$ : upwelling centers and variations in crustal thickness. Marine Geophysical Research, 10, 205-232.

Langmuir, C. H. \& Bender, J. F. 1984. The geochemistry of oceanic basalts in the vicinity of transform faults: observations and implications. Earth and Planetary Science Letters, 69, 107-127.

Langmuir, C. H., Bender, J. F., Bence, A. E., Hanson, G. N. \& TAYLOR, S. R. 1977. Petrogenesis of basalts from the FAMOUS area: mid-Atlantic Ridge. Earth and Planetary Science Letters, 36, 133-156.

LANGmuir, C. H., Bender, J. F. \& Batiza, R. 1986. Petrological and tectonic segmentation of the East Pacific Rise, $5^{\circ} 30^{\prime}-14^{\circ} 30^{\prime} \mathrm{N}$. Nature, 322, 422-429.

Langmuir, C. H., Klein, E. M. \& Plank, T. 1992. Petrological systematics of mid-ocean ridge basalts: constraints on melt generation beneath ocean ridges. In: Phipps Morgan, J., Blackman, D. K. \& Sinton, J. M. (eds) Mantle Flow and Melt Generation at MidOcean Ridges. American Geophysical Union Monograph, 71, 183-280, http://dx.doi.org/10.1029/ GM071p0183

Le Douaran, S. \& Francheteau, J. 1981. Axial depth anomalies from 10 to 50 north along the Mid-Atlantic Ridge: correlation with other mantle properties. Earth and Planetary Science Letters, 54, 29-47

Lin, J. \& Phipps Morgan, J. 1992. The spreading rate dependence of three-dimensional mid-ocean ridge gravity structure. Geophysical Research Letters, 19, $13-16$.

Lin, J., Purdy, G. M., Schouten, H., Sempéré, J.-C. \& Zervas, C. 1990. Evidence from gravity data for focused magmatic accretion along the Mid-Atlantic Ridge. Nature, 344, 627-632.

Lonsdale, P. 1983. Overlapping rift zones at the $5.5 \mathrm{~S}$ offset of the East Pacific Rise. Journal of Geophysical Research, 88, 9393-9406.

LONSDAle, P. 1985. Nontransform offsets of the PacificCocos plate boundary and their traces on the rise flank. Geological Society of America Bulletin, 96, 313-327.

Lonsdale, P. 1989. Segmentation of the Pacific-Nazca Spreading Center, $1^{\circ} \mathrm{N}-20^{\circ} \mathrm{S}$. Journal of Geophysical Research, 94, 12 197-12 225.

LONSDAlE, P. 1994. Geomorphology and structural segmentation of the crest of the southern (PacificAntarctic) East Pacific Rise. Journal of Geophysical Research, 99, 4683-4702.

Macdonald, K. C. 1986. The crest of the Mid-Atlantic Ridge: models for crustal generation processes and tectonics. In: Vogt, P. R. \& Tucholke, B. E. (eds) The Geology of North America, Volume M. Geological Society of America, Boulder, CO, 51-68.

MaCDONALD, K. C. \& Fox, P. J. 1983. Overlapping spreading centers: new accretion geometry on the East Pacific Rise. Nature, 301, 55-58.

Macdonald, K. C. \& Fox, P. J. 1988. The axial summit graben and cross-sectional shape of the East Pacific Rise as indicators of axial magma chambers and recent volcanic eruptions. Earth and Planetary Science Letters, 88, 119-131.
Macdonald, K., Sempere, J. C. \& Fox, P. J. 1984 East Pacific Rise from Siqueiros to Orozco fracture zones: along-strike continuity of axial neovolcanic zone and structure and evolution of overlapping spreading centers. Journal of Geophysical Research, 89, 6049-6069.

Macdonald, K. C., Fox, P. J. ET AL. 1988. A new view of the mid-ocean ridge from the behavior of ridge axis discontinuities. Nature, 335, 217-225.

Macdonald, K. C., Fox, P. J. ET AL. 1992. The East Pacific Rise and its flanks $8-18^{\circ} \mathrm{N}$ : history of segmentation, propagation and spreading direction based on SeaMARC II and Sea Beam studies. Marine Geophysical Research, 14, 299-344.

Macleod, C. J., Teagle, D. A. H. et AL. 2008. Accretion of the lower oceanic crust at fast-spreading ridges: a rock drill and near-bottom seafloor survey in support of IODP drilling in Hess Deep. RRS James Cook JC21 Cruise Report, Cardiff University, UK.

Magde, L. S. \& Detrick, R. S. 1995. Crustal and upper mantle contribution to the axial gravity anomaly at the southern East Pacific Rise. Journal of Geophysical Research, 100, 3747-3766.

Magde, L. S. \& Sparks, D. W. 1997. Three-dimensional mantle upwelling, melt generation, and melt migration beneath segment slow spreading ridges. Journal of Geophysical Research, 102, 20 571-20 583.

Mahoney, J. J., Sinton, J. M., Kurz, M. D., MacdouGall, J. D., Spencer, K. J. \& Lugmair, G. W. 1994. Isotope and trace element characteristics of a super-fast spreading ridge: east Pacific Rise, $13-23^{\circ} \mathrm{S}$. Earth and Planetary Science Letters, 121, 173-193.

Mahoney, J. J., Graham, D. W., Christie, D. M., Johnson, K. T. M., HALl, L. S. \& VonderhaAR, D. L. 2002. Between a hotspot and a cold spot: isotopic variation in the Southeast Indian Ridge asthenosphere, 86 E-118 E. Journal of Petrology, 43, $1155-1176$.

Marjanovic, M. 2013. Signature of Present and Past Melt Distribution Along Fast and Intermediate Spreading Centers. PhD thesis, Columbia University, New York.

Mendel, V., Sauter, D., Parson, L. \& Vanney, J. 1997. Segmentation and morphotectonic variations along a super slow-spreading center: the Southwest Indian Ridge (57 E-70 E). Marine Geophysical Researches, 19, 505-533.

Mendel, V., Sauter, D., Rommevaux-Jestin, C., Patriat, P., Lefebvre, F. \& Parson, L. M. 2003. Magmato-tectonic cyclicity at the ultra-slow spreading Southwest Indian Ridge: evidence from variations of axial volcanic ridge morphology and abyssal hills pattern. Geochemistry, Geophysics, Geosystems, 4, http://dx.doi.org/10.1029/2002GC000417

Meyzen, C., Ludden, J., Humler, E., Luais, B., Toplis, M., Mével, C. \& Storey, M. 2005. New insights into the origin and distribution of the DUPAL isotope anomaly in the Indian Ocean mantle from MORB of the Southwest Indian Ridge. Geochemistry, Geophysics, Geosystems, 6, Q11K11.

Michael, P. J., Forsyth, D. W. et AL. 1994. Mantle control of a dynamically evolving spreading center: mid-Atlantic Ridge 31-34 S. Earth and Planetary Science Letters, 121, 451-468. 


\section{S. M. CARBOTTE ET AL.}

Michael, P., Langmuir, C. ET AL. 2003. Magmatic and amagmatic seafloor generation at the ultraslowspreading Gakkel ridge: Arctic Ocean. Nature, 423, 956-961.

Minshull, T. A. \& White, R. S. 1996. Thin crust on the flanks of the slow-spreading Southwest Indian Ridge. Geophysical Journal International, 125, 139-148.

Minshull, T., Muller, M. \& White, R. 2006. Crustal structure of the Southwest Indian Ridge at $66^{\circ} \mathrm{E}$ : seismic constraints. Geophysical Journal International, 166, 135-147.

Montesi, L. G., Behn, M. D., Hebert, L. B., Lin, J. \& BARRY, J. L. 2011. Controls on melt migration and extraction at the ultraslow Southwest Indian Ridge 10-16 E. Journal of Geophysical Research, 116, http://dx.doi.org/10.1029/2011JB008259

Müller, C. \& JoKat, W. 2000. Seismic evidence for volcanic activity discovered in central Arctic. Eos, Transactions American Geophysical Union, 81, 265-269.

Muller, M. R., Minshull, T. A. \& White, R. S. 1999. Segmentation and melt supply at the Southwest Indian Ridge. Geology, 27, 867-870.

MutTer, J. C. \& Karson, J. A. 1992. Structural processes at slow-spreading ridges. Science, 257, 627-634.

Neumann, G. A. \& Forsyth, D. W. 1993. The paradox of the axial profile: isostatic compensation along the axis of the Mid-Atlantic Ridge? Journal of Geophysical Research, 98, 17 891-17.

Nicolas, A., Boudier, F. \& Ildefonse, B. 1994. Evidence from the Oman ophiolite for active mantle upwelling beneath a fast-spreading ridge. Nature, 370, 51-53.

NiU, Y. \& BATIZA, R. 1994. Magmatic processes at a slow spreading ridge segment: $26^{\circ} \mathrm{S}$ Mid-Atlantic Ridge. Journal of Geophysical Research, 99, 19 719-19 740.

Ohara, Y., Yoshida, T. \& Kasuga, S. 2001. Giant megamullion in the Perece Vela Backarc basin. Marine Geophysical Research, 22, 47-61.

Okino, K., Curewitz, D., Asada, M., Tamaki, K., Vogt, P. \& Crane, K. 2002. Preliminary analysis of the Knipovich Ridge segmentation: influence of focused magmatism and ridge obliquity on an ultraslow spreading system. Earth and Planetary Science Letters, 202, 275-288

Okino, K., Matsuda, K., Christie, D., Nogi, Y. \& KoIzUMI, K. 2004. Development of oceanic detachment and asymmetric spreading at the Australian-Antarctic Discordance. Geochemistry. Geophyics. Geosystems, 5, http://dx.doi.org/10.1029/2004GC000793

Olive, J.-A., Behn, M. D. \& Tucholke, B. E. 2010. The structure of oceanic core complexes controlled by the depth distribution of magma emplacement. Nature Geoscience, 3, http://dx.doi.org/10.1038/NGEO888

Parmentier, E. M. \& Phipps Morgan, J. 1990. Spreading rate dependence of three-dimensional structure in oceanic spreading centres. Nature, 348, 325-328.

Perfit, M. R. \& Chadwick, W. W. 1998. Magmatism at mid-ocean ridges: constraints from volcanological and geochemical investigations. In: BUCK, W. R., Delaney, P. T., Karson, J. A. \& Lagabrielle, Y. (eds) Faulting and Magmatism at Mid-Ocean Ridges. American Geophysical Union, Washington, DC, Geophysical Monograph, 106, 59-115, http://dx.doi.org/ 10.1029/GM106p0059
Perfit, M. R., Fonari, D. J., Smith, M. C., Bender, J. F., LANGmuir, C. H. \& HaYmon, R. M. 1994. Small-scale spatial and temporal variations in mid-ocean ridge crest magmatic processes. Geology, 22, 375-379.

Phipps Morgan, J. \& Chen, Y. J. 1993. The genesis of oceanic crust: Magma injection, hydrothermal circulation, and crustal flow. Journal of Geophysical Research, 98, 6283-6297.

Purdy, G. M. \& Detrick, R. S. 1986. Crustal structure of the Mid-Atlantic Ridge at $23^{\circ} \mathrm{N}$ from seismic refraction studies. Journal of Geophysical Research, 91, 3739-3762.

Rabinowicz, M. \& Briais, A. 2002. Temporal variations of the segmentation of slow to intermediate spreading mid-ocean ridges 2. A three-dimensional model in terms of lithosphere accretion and convection within the partially molten mantle beneath the ridge axis. Journal of Geophysical Research, 107, ECV-2.

Rabinowicz, M., Ceuleneer, G. \& Nicolas, A. 1987. Melt segregation and flow in mantle diapirs below spreading centers: evidence from the Oman ophiolite. Journal of Geophysical Research, 92, 3475-3486.

Reston, T. J. \& Ranero, C. R. 2011. The 3-D geometry of detachment faulting at mid-ocean ridges. Geochemistry. Geophyics. Geosystems, 12, Q0AG05, http://dx. doi.org/10.1029/2011GC003666

Reynolds, J. R. \& LANGMuir, C. H. 1997. Petrological systematics of the Mid-Atlantic Ridge south of Kane: implications for ocean crust formation. Journal of Geophysical Research, 102, 14 915-14.

Reynolds, J. R., Langmuir, C. H., Bender, J. F., Kastens, K. A. \& Ryan, W. B. 1992. Spatial and temporal variability in the geochemistry of basalts from the East Pacific Rise. Nature, 359, 493-499.

Rommevaux-Jestin, C., Deplus, C. \& Patriat, P. 1997. Mantle Bouguer anomaly along an ultra slowspreading ridge: implications for accretionary processes and comparison with results from central Mid-Atlantic Ridge. Marine Geophysical Researches, 19, 481-503.

Rubin, K. H. \& Sinton, J. M. 2007. Inferences on midocean ridge thermal and magmatic structure from MORB composition. Earth and Planetary Science Letters, 260, 257-276.

Russo, C. J., Rubin, K. H. \& Graham, D. W. 2009. Mantle melting and magma supply to the Southeast Indian Ridge: the roles of lithology and melting conditions from U-series disequilibria. Earth and Planetary Science Letters, 278, 55-66.

Ryan, W. B., Carbotte, S. M. et aL. 2009. Global MultiResolution Topography synthesis. Geochemistry, Geophysics, Geosystems, 10, http://dx.doi.org/10.1029/ 2008GC002332

SANDWELL, D. T. 1986. Thermal stress and the spacings of transform faults. Journal of Geophysical Research, 91, 6405-6417.

SANDWELl, D. T. \& Smith, W. H. F. 1997. Marine gravity anomaly from Geosat and ERS 1 satellite altimetry. Journal of Geophysical Research, 102,10 039-10 054.

Sauter, D. \& CANnat, M. 2010. The ultraslow spreading Southwest Indian Ridge. In: Rona, P. A., Devey, C. W., Dyment, J. \& Murton, B. J. (eds) Diversity of Hydrothermal Systems on Slow Spreading Ocean Ridges. American Geophysical Union, Washington 


\section{SEGMENTATION OF MID-OCEAN RIDGES}

DC,Geophysical Monograph, 188, 153-173, http:// dx.doi.org/10.1029/2008GM000843

Sauter, D., Patriat, P., Rommevaux-Jestin, C., Cannat, M. \& BriaIs, A. 2001. The Southwest Indian Ridge between $49^{\circ} 15^{\prime} \mathrm{E}$ and $57^{\circ} \mathrm{E}$ : focused accretion and magma redistribution. Earth and Planetary Science Letters, 192, 303-317.

SAuter, D., Mendel, V. et AL. 2004. Focused magmatism v. amagmatic spreading along the ultra-slow spreading Southwest Indian Ridge: evidence from TOBI side scan sonar imagery. Geochemistry Geophysics Geosystems, 5, Q10K09.

Sauter, D., Cannat, M. et al. 2013. Continuous exhumation of mantle-derived rocks at the Southwest Indian Ridge for 11 million years. Nature Geoscience, 6, 314-320, http://dx.doi.org/10.1038/ngeo1771

ScheIrer, D. S. \& MacdonAld, K. C. 1993. Variation in cross-sectional area of the axial ridge along the East Pacific Rise: evidence for the magmatic budget of a fast-spreading center. Journal of Geophysical Research, 98, 7871-7885.

Scheirer, D. S., Macdonald, K. C., Forsyth, D. W., Miller, S. P., Wright, D. J., Cormier, M. H. \& WeIland, C. M. 1996. A map series of the southern East Pacific Rise and its flanks, $15 \mathrm{~S}$ to $19 \mathrm{~S}$. Marine Geophysical Researches, 18, 1-12.

Schilling, J. G., Kingsley, R. H. \& Devine, J. D. 1982. Galápagos hot spot-spreading center system: 1. Spatial petrological and geochemical variations $\left(83^{\circ} \mathrm{W}-\right.$ $\left.101^{\circ} \mathrm{W}\right)$. Journal of Geophysical Research, 87, 5593-5610.

Schilling, J. G., Zajac, M., Evans, R., Johnston, T., White, W., Devine, J. D. \& Kingsley, R. 1983. Petrologic and geochemical variations along the MidAtlantic Ridge from $29^{\circ} \mathrm{N}$ to $73^{\circ} \mathrm{N}$. American Journal of Science, 283, 510-586.

Schlindwein, V., Demuth, A., Geissler, W. H. \& JOKAT, W. 2013. Seismic gap beneath Logachev Seamount: indicator for melt focusing at an ultraslow mid-ocean ridge? Geophysical Research Letters, 40, 1703-1707, http://dx.doi.org/10.1002/grl.50329

Schouten, H. \& Klitgord, K. D. 1982. The memory of the accreting plate boundary and the continuity of fracture zones. Earth and Planetary Science Letters, 59, $255-266$

Schouten, H. \& White, R. S. 1980. Zero-offset fracture zones. Geology, 8, 175-179.

Schouten, H., Klitgord, K. D. \& Whitehead, J. A. 1985. Segmentation of mid-ocean-ridges. Nature, 317, 225-229.

Schouten, H., Dick, H. J. B. \& Klitgord, K. D. 1987. Migration of mid-ocean-ridge volcanic segments. Nature, 326, 835-839.

Schroeder, T., Cheadle, M. J., Dick, H. J., Faul, U., Casey, J. F. \& Kelemen, P. B. 2007. Nonvolcanic seafloor spreading and corner-flow rotation accommodated by extensional faulting at $15^{\circ} \mathrm{N}$ on the MidAtlantic Ridge: a structural synthesis of ODP Leg 209. Geochemistry, Geophysics, Geosystems, 8, http://doi.org/10.1029/2006GC001567

Searle, R. C. 2013. Mid Ocean Ridge. Cambridge University Press.

Searle, R. C., Cannat, M., Fujioka, K., Mevel, C., Fujimoto, H., Bralee, A. \& Parson, L. 2003. FUJI Dome: a large detachment fault near $64 \mathrm{oE}$ on the very slowspreading Southwest Indian Ridge. Geochemistry, Geophyics, Geosystems, 4, http://dx.doi.org/10.1029/ 2003GC000519

Sempéré, J.-C., Purdy, G. M. \& Schouten, H. 1990. Segmentation of the Mid-Atlantic Ridge between $24^{\circ} \mathrm{N}$ and $30^{\circ} 40^{\prime} \mathrm{N}$. Nature, 344, 427-431.

Sempéré, J.-C., Lin, J., Brown, H. S., Schouten, H. \& PURDY, G. M. 1993. Segmentation and morphotectonic variations along a slow-spreading center: the MidAtlantic Ridge $\left(24^{\circ} 00^{\prime} \mathrm{N}-30^{\circ} 40^{\prime} \mathrm{N}\right)$. Marine Geophysical Research, 15, 153-200.

Sempéré, J. C., Cochran, J. R. SEIR Team. 1997. The Southeast Indian Ridge between $88 \mathrm{E}$ and $118 \mathrm{E}$ : variations in crustal accretion at constant spreading rate. Journal of Geophysical Research, 102, 15 489-15 506.

Severinghaus, J. P. \& Macdonald, K. C. 1988. High inside corners at ridge-transform intersections. Marine Geophysical Researches, 9, 353-367.

Seyler, M., Cannat, M. \& Mével, C. 2003. Evidence for major-element heterogeneity in the mantle source of abyssal peridotites from the Southwest Indian Ridge (52 to 68 E). Geochemistry, Geophysics, Geosystems, 4, 9101

SHAw, P. R. 1992. Ridge segmentation, faulting and crustal thickness in the Atlantic Ocean. Nature, 358, 490-493.

ShaW, P. R. \& LiN, J. 1993. Causes and consequences of variations in faulting style at the Mid-Atlantic Ridge. Journal of Geophysical Research, 98, 21 839-21 851.

Shirey, S. B., Bender, J. F. \& Langmuir, C. H 1987. Three-component isotopic heterogeneity near the Oceanographer Transform, Mid-Atlantic Ridge. Nature, 325, 217-223.

Simão, N., Escartín, J., Goslin, J., Haxel, J., Cannat, M. \& DZIAK, R. 2010. Regional seismicity of the MidAtlantic Ridge: observations from autonomous hydrophone arrays. Geophysical Journal International, $\mathbf{1 8 3}$, $1559-1578$.

Sims, K. W. W., Goldstein, S. J. et AL. 2002. Chemical and isotopic constraints on the generation and transport of magma beneath the East Pacific Rise. Geochimica et Cosmochimica Acta, 66, 3481-3504.

SingH, S. C., HaRding, A. J. ET AL. 2006a. Seismic reflection images of the Moho underlying melt sills at the East Pacific Rise. Nature, 442, 287-290.

Singh, S. C., Crawford, W. C. ET AL. 2006b. Discovery of a magma chamber and faults beneath a Mid-Atlantic Ridge hydrothermal field. Nature, 442, 1029-1032.

Sinha, M. C., Constable, S. C., Peirce, C., White, A., Heinson, G., MacGregor, L. M. \& Navin, D. A. 1998. Magmatic processes at slow spreading ridges: implications of the RAMESSES experiment at $5745^{\prime}$ $\mathrm{N}$ on the Mid-Atlantic Ridge. Geophysical Journal International, 135, 731-745.

Sinton, J. M. \& Detrick, R. S. 1992. Mid-ocean ridge magma chambers. Journal of Geophysical Research, 97, 197-216.

Sinton, J. M., Smaglik, S. M., Mahoney, J. J. \& MacdoNALD, K. C. 1991. Magmatic processes at superfast spreading mid-ocean ridges: glass compositional variations along the East Pacific Rise $13^{\circ}-23^{\circ} \mathrm{S}$. Journal of Geophysical Research, 96, 6133-6155. 


\section{S. M. CARBOTTE ET AL.}

Sinton, J., Detrick, R., Canales, J. P., Ito, G. \& Behn, M. 2003. Morphology and segmentation of the western Galápagos Spreading Center, 90.5-98 W: plume-ridge interaction at an intermediate spreading ridge. Geochemistry, Geophysics, Geosystems, 4, http://dx.doi. org/10.1029/2003GC000609

Small, C. 1998. Global Systematics of Mid-Ocean Ridge Morphology. In: Buck, W. R., Delaney, P. T., Karson, J. A. \& Lagabrielle, Y. (eds) Faulting and Magmatism at Mid-Ocean Ridges. American Geophysical Union, Washington, DC, Geophysical Monograph, 106, 1-26.

Small, C., Cochran, J. R., Sempéré, J. C. \& Christie, D. 1999. The structure and segmentation of the Southeast Indian Ridge. Marine Geology, 161, 1-12.

Smith, D. K. \& CanN, J. R. 1993. Building the crust at the Mid-Atlantic Ridge. Nature, 365, 707-715.

Smith, D. K. \& CanN, J. R. 1999. Constructing the upper crust of the Mid-Atlantic Ridge; a reinterpretation based on the Puna Ridge, Kilauea Volcano. Journal of Geophysical Research, 104, 25 379-25 399.

Smith, D. K., CANN, J. R. ET AL. 1995. Mid-Atlantic Ridge volcanism from deep-towed side-scan sonar images, $25^{\circ}-29^{\circ}$ N. Journal of Volcanology and Geothermal Research, 67, 233-262.

Smith, D. K., Escartin, J., Cannat, M., Tolstoy, M., Fox, C. G., Bohnenstiehl, D. R. \& Bazin, S. 2003. Spatial and temporal distribution of seismicity along the northern Mid-Atlantic Ridge $\left(15^{\circ}-35^{\circ} \mathrm{N}\right)$. Journal of Geophysical Research, 108, http://doi.org/10. 1029/2002JB001964

Smith, D. K., Cann, J. R. \& Escartin, J. 2006. Widespread active detachment faulting and core complex formation near $13 \mathrm{oN}$ on the Mid-Atlantic Ridge. Nature, 442, 440-443, http://dx.doi.org/10.1038/ nature 04950

Smith, D. K., Escartin, J., Schouten, H. \& Cann, J. R. 2008. Fault rotation and core complex formation: significant processes in seafloor formation at slowspreading mid-ocean ridges (Mid-Atlantic Ridge, $13-$ 25oN). Geochemistry, Geophysics, Geosystems, 9, Q03003, http://dx.doi.org/10.1029/2007GC001699

Smith, M. C., Perfit, M. R., Fornari, D. J., Ridley, W. I., Edwards, M. H., Kurras, G. J. \& Von Damm, K. L. 2001. Magmatic processes and segmentation at a fast spreading mid-ocean ridge: detailed investigation of an axial discontinuity on the East Pacific Rise crest at $937^{\prime}$ N. Geochemistry, Geophysics, Geosystems, 2 , http://dx.doi.org/10.1029/2000GC000134

Soule, S. A., Escartín, J. \& Fornari, D. J. 2009. A record of eruption and intrusion at a fast spreading ridge axis: axial summit trough of the East Pacific Rise 9-10oN. Geochemistry, Geophysics, Geosystems, 10, Q10T07.

Sparks, D. W. \& Parmentier, E. M. 1991. Melt extraction from the mantle beneath spreading centers. Earth and Planetary Science Letters, 105, 368-377.

Sparks, D. W. \& Parmentier, E. M. 1993. The structure of three-dimensional convection beneath oceanic spreading centres. Geophysical Journal International, 112, 81-91.

Spencer, S., Smith, D. K., CANN, J. R., Lin, J. \& MCAllISTER, E. 1997. Structure and stability of non- transform discontinuities on the Mid-Atlantic Ridge between $24^{\circ} \mathrm{N}$ and $30^{\circ} \mathrm{N}$. Marine Geophysical Researches, 19 , 339-362.

Spiegelman, M. \& McKenzie, D. 1987. Simple 2-D models for melt extraction at mid-ocean ridges and island arcs. Earth and Planetary Science Letters, 83, $137-152$.

Standish, J. J., Dick, H. J., Michael, P. J., Melson, W. G. \& O'HEARN, T. 2008. MORB generation beneath the ultraslow spreading Southwest Indian Ridge (9-25 E): major element chemistry and the importance of process v. source. Geochemistry, Geophysics, Geosystems, 9, http://dx.doi.org/10.1029/2008GC001959

Tapponnier, P. \& Francheteau, J. 1978. Necking of the lithosphere and the mechanics of slowly accreting plate boundaries. Journal of Geophysical Research, 83, 3955-3970.

Thibaud, R., Gente, P. \& Maia, M. 1998. A systematic analysis of the Mid-Atlantic Ridge morphology and gravity between $15^{\circ} \mathrm{N}$ and $40^{\circ} \mathrm{N}$ : constraints of the thermal structure. Journal of Geophysical Research, 103, $24223-24243$.

Thompson, G., Bryan, W. B., Ballard, R., Hamuro, K. \& Melson, W. G. 1985. Axial processes along a segment of the East Pacific Rise, 10-12 N. Nature, 318, 429-433.

Tolstoy, M., Harding, A. J. \& Orcutt, J. A. 1993. Crustal thickness on the Mid-Atlantic Ridge: bull's-eye gravity anomalies and focussed accretion. Science, 262, 726-729.

Tolstoy, M., Bohnenstiehl, D. R., Edwards, M. H. \& Kurras, G. J. 2001. Seismic character of volcanic activity at the ultraslow-spreading Gakkel Ridge. Geology, 29, 1139-1142.

Toomey, D. R. \& Hooft, E. E. 2008. Mantle upwelling, magmatic differentiation, and the meaning of axial depth at fast-spreading ridges. Geology, 36, 679-682.

Toomey, D. R., Solomon, S. C. \& Purdy, G. M. 1988. Microearthquakes beneath Median Valley of MidAtlantic Ridge near $23^{\circ} \mathrm{N}$ : tomography and tectonics. Journal of Geophysical Research, 93, 9093-9112.

Toomey, D. R., Purdy, G. M., Solomon, S. C. \& WiLcock, W. S. D. 1990. The three-dimensional seismic velocity structure of the East Pacific Rise near latitude $9^{\circ} 30^{\prime} \mathrm{N}$. Nature, 347, 639-645.

Toomey, D. R., Jousselin, D., Dunn, R. A., Wilcock, W. S. D. \& Detrick, R. S. 2007. Skew of mantle upwelling beneath the East Pacific Rise governs segmentation. Nature, 446, http://dx.doi.org/10.1038/ nature 05679

Tucholke, B. E. \& Lin, J. 1994. A geological model for the structure of ridge segments in slow spreading ocean crust. Journal of Geophysical Research, 99, 11937-11958.

Tucholke, B. E. \& Schouten, H. 1988. Kane fracture zone. Marine Geophysical Researches, 10, 1-39.

Tucholke, B. E., Lin, J. \& Kleinrock, M. C. 1998. Megamullions and mullion structure defining oceanic metamorphic core complexes on the midAtlantic ridge. Journal of Geophysical Research, 103, 9857-9866.

Tucholke, B. E., Behn, M. D., Buck, W. R. \& Lin, J. 2008. Role of melt supply in oceanic detachment faulting and formation of megamullions. Geology, 36, 455-458, http://dx.doi.org/10.1130/G24639A.1 


\section{SEGMENTATION OF MID-OCEAN RIDGES}

van Avendonk, H. J. A., Harding, A. J., Orcutt, J. A. \& MCClain, J. 1998. A two-dimensional tomographic study of the Clipperton transform fault. Journal of Geophysical Research, 103, 17885-17899.

Wang, X., Cochran, J. R. \& Barth, G. A. 1996. Gravity anomalies, crustal thickness, and the pattern of mantle flow at the fast spreading East Pacific Rise, $9^{\circ}-10^{\circ} \mathrm{N}$ : evidence for three-dimensional upwelling. Journal of Geophysical Research, 101, 17 927-17 940.

Wanless, V. D., Perfit, M. R., Ridley, W. I. \& Klein, E. 2010. Dacite petrogenesis on mid-ocean ridges: evidence for oceanic crustal melting and assimilation. Journal of Petrology, 51, 2377-2410.

Weiland, C. M. \& Macdonald, K. C. 1996. Geophysical study of the East Pacific Rise $15^{\circ} \mathrm{N}-17^{\circ} \mathrm{N}$ : an unusually robust segment. Journal of Geophysical Research, 101, 20 257-20 273.

West, B. P., Sempéré, J. C., Pyle, D. G., Phipps Morgan, J. \& Christie, D. M. 1994. Evidence for variable upper mantle temperature and crustal thickness in and near the Australian-Antarctic Discordance. Earth and Planetary Science Letters, 128, 135-153.

White, S. M., Macdonald, K. C. \& Haymon, R. M. 2000. Basaltic lava domes, lava lakes, and volcanic segmentation on the southern East Pacific Rise. Journal of Geophysical Research, 105, 23 519-23 536.

White, S. M., Haymon, R. M., Fornari, D. J., Perfit, M. R. \& Macdonald, K. C. 2002. Correlation between volcanic and tectonic segmentation of fast-spreading ridges: evidence from volcanic structures and lava flow morphology on the East Pacific Rise at $9^{\circ}-10^{\circ}$ N. Journal of Geophysical Research, 107, 2173.

White, S. M., Haymon, R. M. \& Carbotte, S. 2006. A new view of ridge segmentation and near-axis volcanism at the East Pacific Rise, $8^{\circ}-12^{\circ} \mathrm{N}$, from EM300 multibeam bathymetry. Geochemistry Geophyics Geosystems, 7, http://dx.doi.org/10.1029/2006GC001407

White, S. M., Meyer, J. D., Haymon, R. M., Macdonald, K. C., Baker, E. T. \& Resing, J. A. 2008. Highresolution surveys along the hot spot-affected Galápagos Spreading Center: 2. Influence of magma supply on volcanic morphology. Geochemistry, Geophysics, Geosystems, 9, http://dx.doi.org/10.1029/2008GC002036

White, S. M., Mason, J. L., Macdonald, K. C., Perfit, M. R., Wanless, V. D. \& Klein, E. M. 2009. Significance of widespread low effusion rate eruptions over the past two million years for delivery of magma to the overlapping spreading centers at 9 N East Pacific Rise. Earth and Planetary Science Letters, 280, 175-184.

White, W. M. \& Schilling, J. G. 1978. The nature and origin of geochemical variation in Mid-Atlantic Ridge basalts from the central North Atlantic. Geochimica et Cosmochimica Acta, 42, 1501-1516.

Whitehead, J. A., Dick, H. J. \& Schouten, H. 1984. A mechanism for magmatic accretion under spreading centres. Nature, 312, 146-148.

Wolfe, C. J., Purdy, G. M., Toomey, D. R. \& Solomon, S. C. 1995. Microearthquake characteristics and crustal velocity structure at $29^{\circ} \mathrm{N}$ on the Mid-Atlantic Ridge: the architecture of a slow spreading segment. Journal of Geophysical Research, 100, 24 449-24 472.

Yamada, T., Tamaki, K., Fujimoto, H. \& Kanazawa, T. 2002. Microearthquakes characteristics at the Jourdanes segment: seismic experiment at 64 E (SWIR). In: InterRidge South West Indian Ridge Workshop, Southampton, UK.

Zhao, M., QiU, X. ET AL. 2013. Three-dimensional seismic structure of a detachment fault and geologic structure of oceanic core complex at Southwest Indian Ridge $\left(49.7^{\circ} \mathrm{E}\right)$. Geochemistry, Geophysics, Geosystems, 14, 4544-4563. 